\title{
Antti Eloranta
}

The Variable Position of Arctic Charr (Salvelinus alpinus (L.)) in Subarctic Lake Food Webs

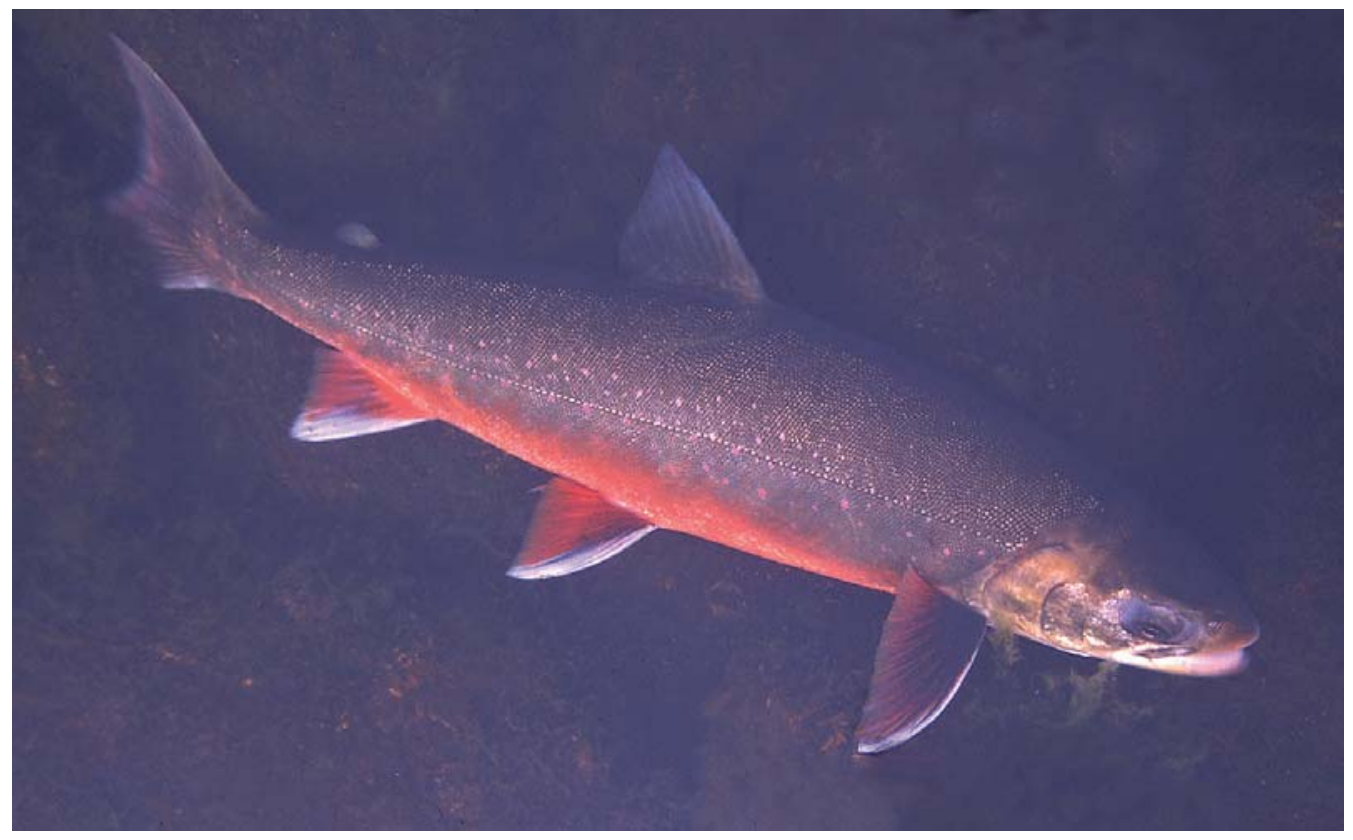




\section{Antti Eloranta}

\section{The Variable Position of Arctic Charr (Salvelinus alpinus (L.)) in Subarctic Lake Food Webs}

Esitetään Jyväskylän yliopiston matemaattis-luonnontieteellisen tiedekunnan suostumuksella julkisesti tarkastettavaksi yliopiston Ambiotica-rakennuksen salissa YAA303 toukokuun 24. päivänä 2013 kello 12.

Academic dissertation to be publicly discussed, by permission of the Faculty of Mathematics and Science of the University of Jyväskylä, in building Ambiotica, hall YAA303, on May 24, 2013 at 12 o'clock noon.

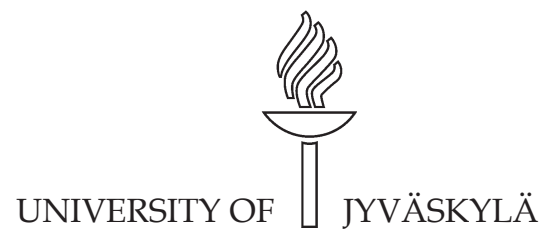

JYVÄSKYLÄ 2013 
The Variable Position of Arctic Charr (Salvelinus alpinus (L.)) in Subarctic Lake Food Webs 
JYVÄSKYLÄ STUDIES IN BIOLOGICAL AND ENVIRONMENTAL SCIENCE 261

\section{Antti Eloranta}

\section{The Variable Position of Arctic Charr (Salvelinus alpinus (L.)) in Subarctic Lake Food Webs}

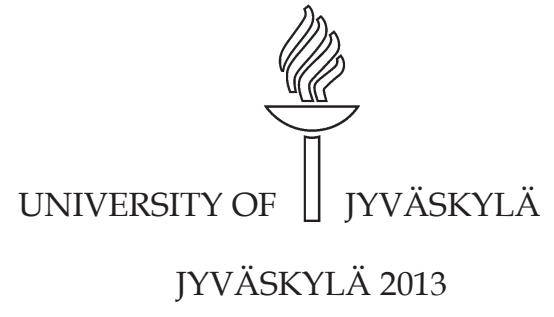


Editors

Timo Marjomäki

Department of Biological and Environmental Science, University of Jyväskylä Pekka Olsbo, Ville Korkiakangas

Publishing Unit, University Library of Jyväskylä

Jyväskylä Studies in Biological and Environmental Science

Editorial Board

Jari Haimi, Anssi Lensu, Timo Marjomäki, Varpu Marjomäki

Department of Biological and Environmental Science, University of Jyväskylä

Cover picture by Tapio Rantala

URN:ISBN:978-951-39-5177-1

ISBN 978-951-39-5177-1 (PDF)

ISBN 978-951-39-5176-4 (nid.)

ISSN 1456-9701

Copyright (C 2013, by University of Jyväskylä

Jyväskylä University Printing House, Jyväskylä 2013 
Dedicated to my brother Heikki, who shared with me his passion for fishing and music. 


\author{
ABSTRACT \\ Eloranta, Antti \\ The variable position of Arctic charr (Salvelinus alpinus (L.)) in subarctic lake food \\ webs \\ Jyväskylä: University of Jyväskylä, 2013, 49 p. \\ (Jyväskylä Studies in Biological and Environmental Science \\ ISSN 1456-9701; 261) \\ ISBN 978-951-39-5176-4 (nid.) \\ ISBN 978-951-39-5177-1 (PDF) \\ Yhteenveto: Nieriän vaihteleva asema subarktisten järvien ravintoverkoissa \\ Diss.
}

Arctic charr (Salvelinus alpinus (L.)) is a cold-adapted salmonid fish with a wide circumpolar distribution. Due to its wide fundamental trophic niche (i.e. diet and habitat use), Arctic charr can be used to study energy flow as well as competitive and predator-prey interactions in subarctic lakes. The objective of this thesis was to evaluate how the trophic niche of Arctic charr in subarctic lakes is influenced by various biotic (e.g. intra- and interspecific resource competition and predation) and abiotic (e.g. seasonality and lake morphometry) factors. Stomach contents and stable isotope analyses indicated marked between-lake and between-individual differences in Arctic charr diet and habitat use. In Saanajärvi, Arctic charr relied mainly on littoral production regardless of season or individual size, probably due to high primary production and lack of sympatric fish species in the littoral zone. In contrast, Arctic charr showed a reduced littoral reliance when the littoral trophic niche was dominated by brown trout, and an increased prevalence of piscivorous foraging when coexisting with planktivorous whitefish and benthivorous grayling. The final results from a total of 17 subarctic lakes indicated that Arctic charr shifted from littoral to a more pelagic trophic niche with increasing lake area and fish species richness. The shift of Arctic charr to a more pelagic piscivorous niche in large lakes was evidently promoted by the existence of small, planktivorous prey fish species and increased interspecific resource competition and/or predation in the littoral zone. The results demonstrate that littoral and pelagic food-web compartments in subarctic lakes can be integrated by generalist Arctic charr, but the energy flow pathways supporting this top consumer can be strongly influenced by prevailing intra- and interspecific interactions as well as by the morphometric characteristics of the lakes. The findings highlight that a comprehensive view of food-web structures is fundamental for predicting the likely responses of fish communities and subarctic lake ecosystems to potential environmental changes.

Keywords: Energy flow; individual specialization; lake morphometry; littoral production; resource competition; stable isotope analysis; trophic niche.

Antti Eloranta, University of Jyväskylä, Department of Biological and Environmental Science, P.O. Box 35, 40014 University of Jyväskylä, Finland 
Author's address Antti Eloranta

Department of Biological and Environmental Science

P.O. Box 35

40014 University of Jyväskylä

Finland

antti.eloranta@jyu.fi

Supervisors

Professor Roger I. Jones

Department of Biological and Environmental Science

P.O. Box 35

40014 University of Jyväskylä

Finland

Dr Kimmo K. Kahilainen

Department of Environmental Sciences

P.O. Box 65

00014 University of Helsinki

Finland

Reviewers

Dr Anders Finstad

Norwegian Institute for Nature Research

Tungasletta 2

N-7485 Trondheim

Norway

Dr Jorma Piironen

Finnish Game and Fisheries Research Institute

Yliopistonkatu 6

80100 Joensuu

Finland

Opponent

Professor Colin Adams

Scottish Centre for Ecology and the Natural Environment University of Glasgow

Rowardennan

Glasgow G63 0AW

Scotland 


\section{CONTENTS}

\section{LIST OF ORIGINAL PUBLICATIONS}

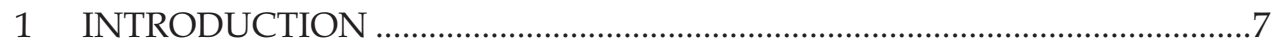

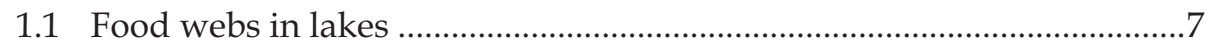

1.2 Subarctic lakes and the Arctic charr......................................................12

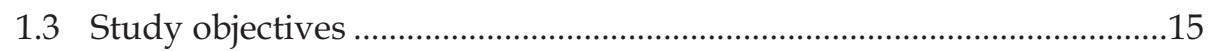

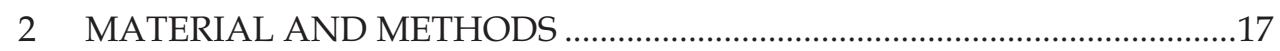

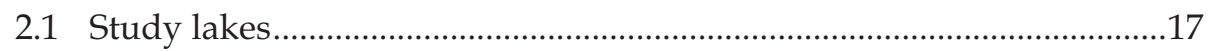

2.2 Sample collection and preparation ..........................................................19

2.2.1 Zooplankton and benthic macroinvertebrates ...............................19

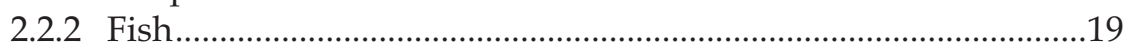

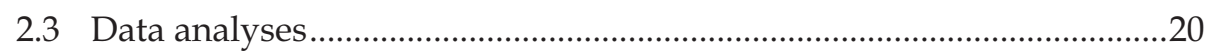

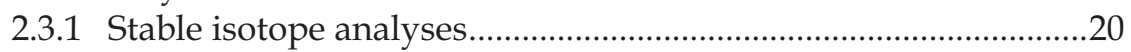

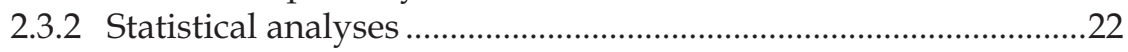

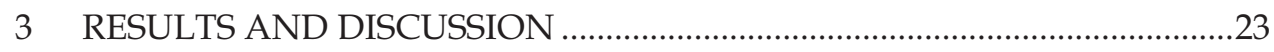

3.1 Seasonal and ontogenetic diet shifts .......................................................2

3.2 Inter- and intraspecific niche segregation ...............................................29

3.2.1 Arctic charr, whitefish and grayling ..................................................29

3.2.2 Arctic charr and brown trout..........................................................30

3.3 Lake morphometry, fish species richness and Arctic charr diet.............32

3.4 Limitations and proposals for future studies ................................................3

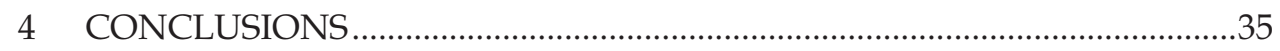

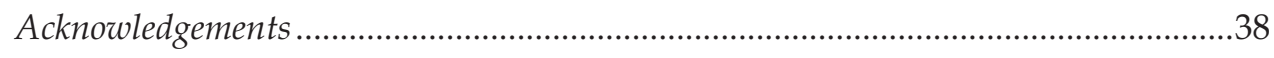

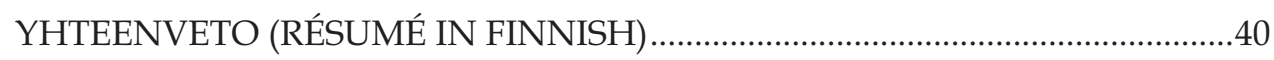

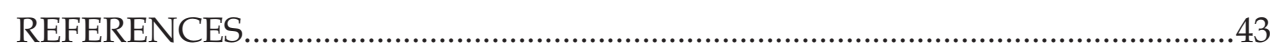




\section{LIST OF ORIGINAL PUBLICATIONS}

The thesis is based on the following original articles, which will be referred to in the text by their Roman numerals I-IV. I did most of the planning for each study and contributed to field work in I, III and IV, and to laboratory analyses in all the studies. I was responsible for the data analysis and wrote the first draft of all the papers. All co-authors made a significant contribution to planning and preparation of the final papers.

I Eloranta A.P., Kahilainen K.K. \& Jones R.I. 2010. Seasonal and ontogenetic shifts in the diet of Arctic charr Salvelinus alpinus in a subarctic lake. Journal of Fish Biology 77: 80-97.

II Eloranta A.P., Siwertsson A., Knudsen R. \& Amundsen P.-A. 2011. Dietary plasticity of Arctic charr (Salvelinus alpinus) facilitates coexistence with competitively superior European whitefish (Coregonus lavaretus). Ecology of Freshwater Fish 20: 558-568.

III Eloranta A.P., Knudsen R. \& Amundsen P.-A. 2013. Niche segregation of coexisting Arctic charr (Salvelinus alpinus) and brown trout (Salmo trutta) constrains food web coupling in subarctic lakes. Freshwater Biology 58: 207221.

IV Eloranta A.P., Kahilainen K.K., Amundsen P.-A., Knudsen R., Harrod C. \& Jones R.I. 2013. Lake size and fish species richness determine resource use by top consumers in subarctic lakes. Manuscript. 


\section{INTRODUCTION}

\subsection{Food webs in lakes}

Lakes are complex ecosystems, whose functioning is tightly connected to the physical, chemical and biological properties of their surrounding catchments and internal habitats (Wetzel 2001, Kalff 2002). While the availability of nutrients, carbon and solar radiation typically sets the limits for primary production, biological interactions between and within species can fundamentally affect the community structure and biodiversity in lake ecosystems. The competitive and predator-prey interactions in lakes have traditionally been illustrated as food-web structures, i.e. by studying who eats whom (e.g. Lindeman 1942). Food web studies typically integrate biodiversity and ecosystem function by focusing on both community composition and fluxes of energy and materials from primary producers up to top consumers (Thompson et al. 2012). One of the central themes in modern food web research has been the importance of linkages between habitats and food-web compartments to the diversity, structure and stability of populations, communities and ecosystems (e.g. Polis \& Strong 1996, Polis et al. 1997, Rooney \& McCann 2012). In lakes, linkages between littoral and pelagic habitats (Fig. 1) can be of fundamental importance for food-web dynamics and ecosystem functioning (Schindler \& Scheuerell 2002, Vadeboncoeur et al. 2002). Limnology has traditionally focused on studying pelagic organisms and processes (Vadeboncoeur et al. 2002), such as trophic interactions between phytoplankton, zooplankton, planktivorous fish and large piscivorous fish (see Carpenter et al. 1987). However, the more heterogeneous littoral zones are often biodiversity "hot-spots" (e.g. Rooney \& McCann 2012) and they can also dominate primary and secondary production, particularly in oligotrophic high-latitude lakes (Vadeboncouer et al. 2003, Karlsson \& Byström 2005, Ask et al. 2009). Compared to most temperate lakes, subarctic and Arctic lakes are relatively unproductive and species-poor and thus ideal ecosystems for studying energy flow pathways from littoral (benthic algae) and pelagic (phytoplankton) primary producers up to top consumers (Christoffersen et al. 2008). Moreover, these lakes may also be particularly sensitive to changes in productivity and 
food-web structures associated with ongoing global warming and changes in fish community compositions (Schindler \& Smol 2006, Jeppesen et al. 2010, 2012).

Many high-latitude lakes are so small and shallow that they freeze solid in winter and thus lack fish. However, in larger and deeper lakes, generalist fish species like Arctic charr (Salvelinus alpinus (L.)) can play an important role in structuring and coupling of littoral and pelagic food-web compartments (Schindler \& Scheuerell 2002, Vander Zanden \& Vadeboncoeur 2002, Christofferesen et al. 2008). Most postglacial lakes situated at high latitudes and altitudes have species-poor fish communities due to extreme environmental conditions and difficulty of colonization (Power et al. 2008). This lack of sympatric competitors has created particularly favourable opportunities for cold-adapted fish species like Arctic charr to maximize exploitation of available food and habitat resources. These fish populations can maximise resource use either by individuals being generalist, or by different groups of individuals having specialized niches, ultimately leading to evolution of distinct morphs and even to speciation (Skúlason \& Smith 1995, Schluter 1996). From an ecosystem perspective, generalist foraging by large, mobile fish top consumers can have a fundamental role in transfer of energy and nutrients between benthic and pelagic habitats (Schindler \& Scheuerell 2002, Vanni 2002).

Generalist foraging on benthic and pelagic prey by fish consumers has been demonstrated to increase food-web stability by weakening interaction strength between predators and their prey (Post et al. 2000a, Rooney \& McCann 2012). Food-web stability is commonly measured as the ability of a food web to remain in or return to its initial condition after a perturbation (Kratina et al. 2012, Rooney \& McCann 2012). Generalist fish may have a particularly stabilizing effect in food webs when the generalist foraging behaviour is associated with ontogenetic niche shifts or when generalist species interfere with each other or feed adaptively (Kratina et al. 2012). For example, generalist fish may switch from a pelagic to a benthic diet if the zooplankton resources become scarce (adaptive foraging), or they may change diet and habitat use as they grow (ontogenetic niche shifts). This potential niche plasticity makes generalist fish species such as Arctic charr not only important habitat integrators, but also ideal study organisms for investigating intra- and interspecific interactions and, in particular, the energy flow through littoral and pelagic food-web compartments in lakes (cf. Vander Zanden \& Vadeboncoeur 2002, Karlsson \& Byström 2005, Vander Zanden et al. 2011).

However, as temperature and fish species richness increase towards lower latitudes and altitudes, cold-adapted generalist species may become competitively inferior and show reduced population sizes and niche use, because particular resources will presumably be better exploited by eurythermal and/or more specialist species (e.g. Jeppesen et al. 2010, 2012). Moreover, several generalist fish species cannot coexist if their trophic niches overlap too much (competitive exclusion principle; Hardin 1960). Consequently, sympatric fish species typically reduce competitive interactions 
by interspecific niche segregation (Nilsson 1965, Vanni et al. 2009). Understanding how the resource use by generalist top consumers is related to different abiotic (e.g. lake morphometry) and biotic factors (e.g. competition and predation) is crucial for evaluating the impacts of potential future changes in productivity and community compositions on the functioning of the sensitive but relatively little studied high-latitude lake ecoystems (Schindler \& Smol 2006, Christoffersen et al. 2008).

Although generalist fish have a wide fundamental trophic niche (i.e. diet and habitat use), the realized niche of populations and individuals is typically restricted due to competitive and predatory interactions between and within fish species (e.g. Vanni et al. 2009, Araújo et al. 2011 and references therein). The competitive interactions between (interspecific) and within (intraspecific) species can be (1) agonistic, if a species or an individual directly prevents the resource use of another, or (2) exploitative, when individuals or species deplete resources that would otherwise be available to others (Vanni et al. 2009). Strong interspecific resource competition may restrict the trophic niche of sympatric species, whereas intraspecific competition may induce individual niche specialization and thus lead to a widened niche use at the population level (cf. Bolnick et al. 2003, Araújo et al. 2011). Hence, the ability of generalist fish species to exploit littoral and pelagic resources may strongly depend on prevailing inter- and intraspecific interactions within the fish community (Vanni et al. 2009, Araújo et al. 2011).

Body size often plays a crucial role in determining the trophic niche of individuals by affecting the energetic requirements, potential for resource exploitation, competitive dominance and predation risk (Werner \& Gilliam 1984). Consequently, generalist fish species typically undergo ontogenetic dietary shifts, e.g. from zooplankton to benthic macroinvertebrates and finally to other fish (Werner \& Gilliam 1984). This intraspecific niche variation typically alleviates resource competition between individuals (Bolnick et al. 2003, Araújo et al. 2011), but can also have a marked influence on the structure and stability of food webs (Woodward et al. 2005, Jansson et al. 2007). For example, large piscivores can regulate the abundance and niche use of smaller conspecifics or fish species (e.g. Werner \& Gilliam 1984, Miller \& Rudolf 2011), which may further lead to trophic cascades regulating the abundance and composition of organisms at the bottom of the food web (Carpenter et al. 1987). Generalist fish species that show marked ontogenetic shifts in diet and habitat use cannot be neatly assigned to a single definite trophic niche (Werner \& Gilliam 1984). This has created a challenge for ecologists trying to solve the consequences of consumer-resource interactions on ecosystem functioning (Miller \& Rudolf 2011). Fortunately, methodological developments in modern food web research have enabled the more reliable and cost-efficient estimation of long-term trophic niche of consumers and, in particular, the evaluation of energy flow through littoral and pelagic trophic pathways in lake ecosystems. 


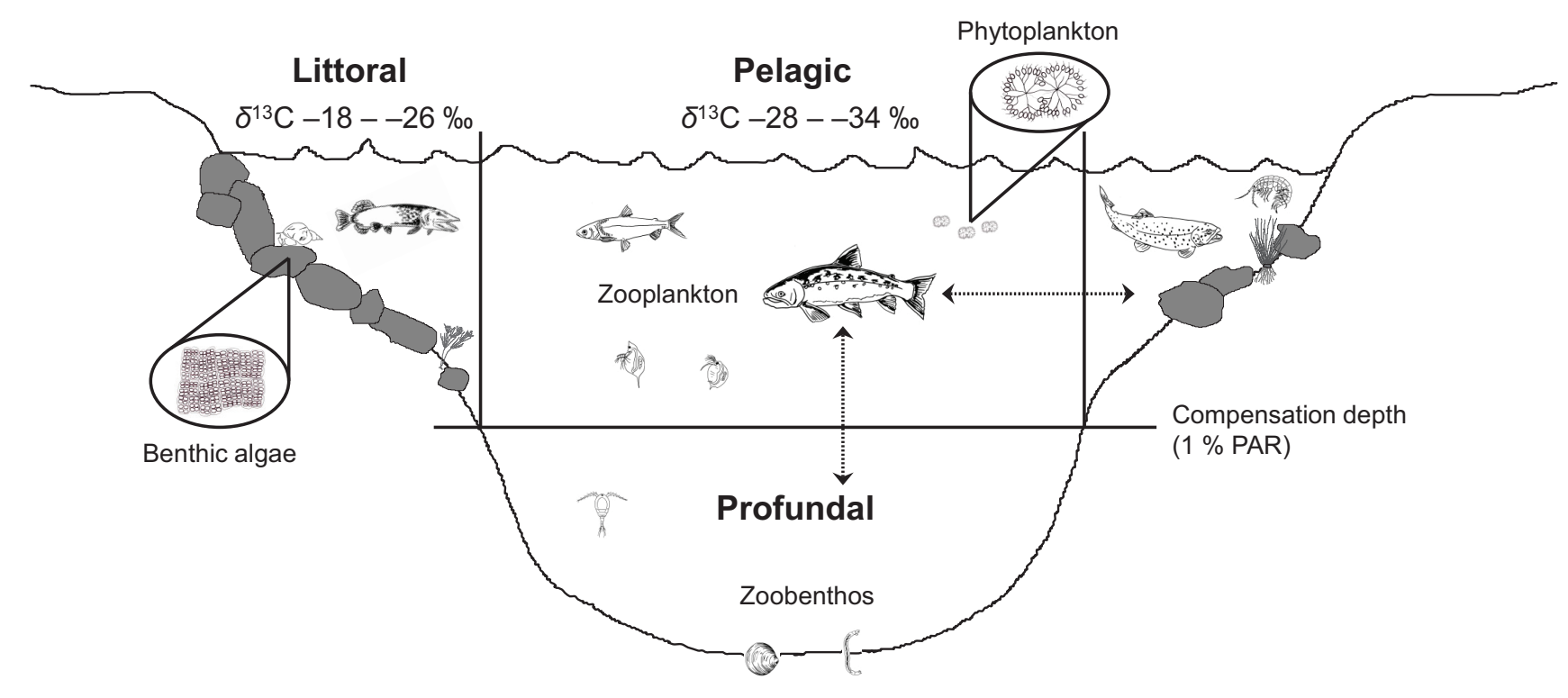

FIGURE 1 Schematic illustration of habitats and food-web compartments in lakes. The littoral zone is delimited as the near-shore, shallow area above the compensation depth at which $\sim 1 \%$ of the photosynthetically available radiation (PAR) at the lake surface reaches the bottom, thereby enabling the growth of benthic algae on the surface of rocks and sediment. These benthic algae are grazed by benthic bottom, thereby enabling the growth of benthic algae on the surface of rocks and sediment. These benthic algae are grazed by benthic
macroinvertebrates (zoobenthos) including snails, amphipods and larvae of aquatic insects. The littoral zone is commonly the most macroinvertebrates (zoobenthos) including snails, amphipods and larvae of aquatic insects. The littoral zone is commonly the most
heterogeneous habitat and shows the highest diversity of invertebrates and fish. The profundal zone is the deep, aphotic bottom area of the lake, where benthic macroinvertebrates, such as small clams and chironomid larvae, are mainly consuming settling or sedimented organic matter produced in the pelagic and littoral areas. The pelagic zone is the photic, open-water area above the profundal zone, where photosynthetic phytoplankton forms the basic energy source for zooplankton and on to planktivorous fish Generalist fish species can switch between habitats and prey resources and thereby increase coupling of littoral and pelagic food-web compartments. However, some habitats and prey items may become inaccessible due to strong interspecific resource competition with, or high predation risk from, sympatric fish species. The littoral and pelagic primary and secondary consumers can often be distinguished by their carbon stable isotope ratios $\left(\delta^{13} \mathrm{C}\right)$. Ceneralist top consumers that derive energy from both littoral and $\mathrm{F}$ sources typically have ${ }^{13} \mathrm{C}$ values between these two extremes. The figure is modified from Schindler \& Scheuerell (2002), and the organisms were drawn by Pekka Antti-Poika. 
Food web and dietary studies have traditionally used stomach contents analysis (SCA) to identify predator-prey relationships and energy flow pathways. However, SCA only gives information about the most recently ingested prey items and thus may not reflect the main, assimilated long-term diet of a consumer. Stable carbon (C) and nitrogen (N) isotope analysis (SIA) has been increasingly used in food web studies to examine the long-term trophic niche of consumers (Layman et al. 2012). In particular, SIA has provided an efficient tool to investigate the energy flow through littoral and pelagic trophic pathways in lake ecosystems (e.g. Hecky \& Hesslein 1995, Vander Zanden \& Vadeboncoeur 2002, Vander Zanden et al. 2011), and to measure individual niche specialization within consumer populations (e.g. Bearhop et al. 2004, Layman et al. 2012). Pelagic phytoplankton are surrounded by excess $\mathrm{CO}_{2}$ and therefore can discriminate against the slightly heavier stable $C$ isotope $\left({ }^{13} \mathrm{C}\right)$ unlike benthic algae that grow on the lake bottom where boundary layers induce more C limitation (Hecky \& Hesslein 1995). Consequently, the pelagic (phytoplankton) and littoral (benthic algae) primary producers usually have distinct stable $C$ isotope ratios $\left({ }^{13} \mathrm{C}:{ }^{12} \mathrm{C}\right.$, denoted as $\delta^{13} \mathrm{C}$; see Fry 2006), which are further reflected to higher consumers, including the pelagic zooplankton and planktivorous fish and the littoral benthic macroinvertebrates and benthivorous fish (Fig. 1 and 2). While $\delta^{13} \mathrm{C}$ shows only minor (0-1 \%o) fractionation between prey and predator, stable $\mathrm{N}$ isotope ratios $\left({ }^{15} \mathrm{~N}:{ }^{14} \mathrm{~N}\right.$, denoted as $\left.\delta 15 \mathrm{~N}\right)$ increase around 3-4 \%o with each trophic step (Post 2002). Consequently, the $\delta^{13} \mathrm{C}$ and $\delta^{15} \mathrm{~N}$ values can be used to determine the trophic position of an organism in the littoral and pelagic food-web compartments. By using stable isotope mixing models, it is also possible to estimate the relative contributions of different prey resources to the long-term diet of consumers (see Layman et al. 2012 and references therein). Hence, SIA can provide a powerful method for investigating energy flow and niche segregation between and within fish species in subarctic lakes. 


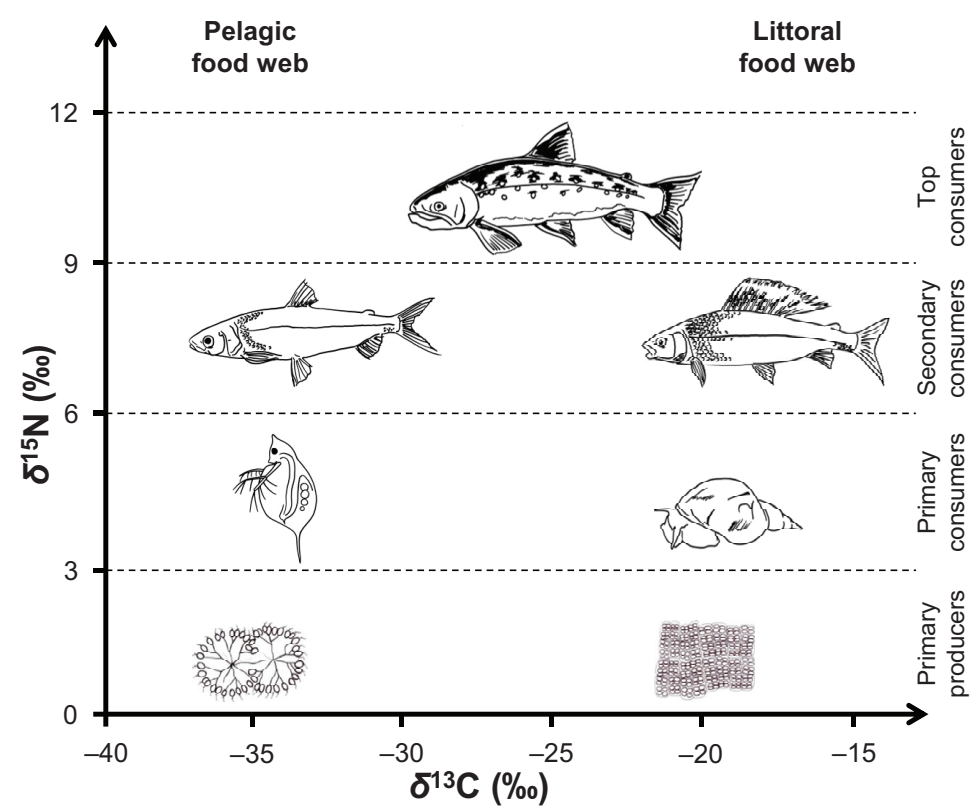

FIGURE 2 A schematic stable isotope biplot showing the distinction between pelagic and littoral food-web compartments and trophic levels in lakes by carbon $\left(\delta^{13} \mathrm{C}\right)$ and nitrogen $\left(\delta^{15} \mathrm{~N}\right)$ isotope ratios, respectively. The stable $\mathrm{C}$ isotopes typically show only a minor trophic fractionation (0-1 \%o) and thus consumers reflect the $\delta^{13} \mathrm{C}$ values of their predominant pelagic and/or littoral food. The $\mathrm{N}$ stable isotopes typically show around 3-4\% enrichment with each trophic step. The littoral and pelagic food-web compartments can be highly integrated by generalist fish species that utilize both benthic and pelagic prey items, and possibly also smaller fish species or conspecifics. Because generalist consumers can rarely be assigned to discrete trophic levels, $\delta^{15} \mathrm{~N}$ has been commonly used as a continuous measure of trophic level in food webs. The organisms were drawn by Pekka Antti-Poika.

\subsection{Subarctic lakes and the Arctic charr}

The subarctic region can be defined in various ways, but is commonly delimited as lying between the northern boreal zone and the Arctic, the latter lying north of the $10{ }^{\circ} \mathrm{C}$ July isotherm (Forsström 2006). These areas are subject to extreme climatic conditions and pronounced seasonal variation in light, temperature and precipitation. Subarctic lakes and ponds are mostly unproductive and often have clear, oligotrophic water due to low input of nutrients and organic matter from the catchment (Vincent et al. 2008). The communities in these waterbodies have commonly been considered especially sensitive to environmental change, including potential changes in productivity and species composition associated with increased temperature and annual ice-free period (Schindler \& Smol 2006, Jeppesen et al. 2010). Fish often have a key role in structuring the food webs in high latitude lakes by controlling the size, abundance and structure of zooplankton and macroinvertebrate communities (Christoffersen et al. 2008). 
The animals can have special adaptations to cope through the cold, dark and unproductive winter; e.g., zooplankton can form resting eggs or store lipids for overwintering (Mariash 2012), whereas the cold-adapted Arctic charr can feed actively throughout the year (Svenning et al. 2007, Amundsen \& Knudsen 2009). The limited and seasonally fluctuating production probably underlies the flexible foraging on benthic and pelagic food resources observed for both zooplankton and fish in subarctic lakes (e.g. Rautio \& Vincent 2006, Amundsen \& Knudsen 2009, Karlsson \& Säwström 2009).

Stable isotope studies have demonstrated that the primary and secondary production in oligotrophic high-latitude lakes is commonly dominated by littoral benthic algae and macroinvertebrates (Sierszen et al. 2003, Vadeboncoeur et al. 2003, Karlsson \& Byström 2005, Ask et al. 2009). In these lakes, the long ice-cover period and scarcity of dissolved nutrients in the water significantly reduces pelagic phytoplankton production, while the clear water enhances light penetration and photosynthesis by benthic algae growing on the rocks and sediment. In contrast, the pelagic phytoplankton production in boreal, temperate and tropical lakes is often supported, and benthic production limited, by high run-off of allochthonous nutrients and organic carbon from the catchment areas (e.g. Vadeboncoeur et al. 2003). Subarctic lakes situated below the tree-line may also show reduced benthic primary (algal) and secondary (invertebrate and fish) production due to increased amount of coloured terrestrial organic matter in the water limiting light penetration and benthic photosynthesis (Karlsson et al. 2009). The relative contributions of littoral and pelagic food-web compartments to lake production may also show seasonal changes (Liboriussen \& Jeppesen 2003, Sadro et al. 2011) and be influenced by lake morphometric characteristics (Kalff 2002, Vadeboncoeur et al. 2008). However, most stable isotope studies have been conducted during one season and in small and shallow high-latitude lakes and ponds (e.g. Vadeboncoeur et al. 2003, Karlsson \& Byström 2005, Ask et al. 2009). Larger and deeper lakes typically have relatively smaller littoral zones and thus may show significantly lower benthic algal production (Kalff 2002, Vadeboncoeur et al. 2008). Consequently, the relative reliance of generalist fish top consumers on littoral and pelagic production in subarctic lakes may be largely determined by seasonal and size-related food availability (Amundsen et al. 2008, Amundsen \& Knudsen 2009), existence of sympatric resource competitors (Nilsson 1965, Svärdson 1976) and lake morphometry (Riget et al. 2000, Dolson et al. 2009).

Arctic charr is a cold-adapted salmonid fish with a wide circumpolar distribution, where it is particularly valuable for recreational and commercial fishing in high-latitude regions, but at the same time is highly endangered at its southern distribution limits (Maitland 1995, Klemetsen et al. 2003). Arctic charr shows remarkable phenotypic plasticity, and in some lakes it has evolved into sympatric morphs that differ in habitat use, diet, morphology and life-history traits (Jonsson \& Jonsson 2001, Klemetsen 2010). Individuals within monomorphic Arctic charr populations can also show marked differences in diet and habitat use, often due to size-related (ontogenetic) differences in feeding 
efficiency and predation risk (Amundsen 1995, Klemetsen et al. 2003). For example, small Arctic charr can be efficient planktivores, but are often forced to feed in the littoral or profundal habitat due to high predation risk in the pelagic open-water area (e.g. L'Abée-Lund et al. 1993, Byström et al. 2004, Amundsen \& Knudsen 2009). Once having reached a large enough size, Arctic charr can specialize in piscivorous foraging on smaller fish species or conspecifics (Amundsen 1994, Klemetsen et al. 2003). The exceptional phenotypic, and sometimes genotypic, variation makes the conservation of Arctic charr especially important, but also challenging (Adams \& Maitland 2007, Adams et al. 2007). On the other hand, due to its sensitivity to climate change, reduced water quality and invasion of new species, Arctic charr can be a good indicator species to investigate changes in the whole ecosystem functioning (Maitland 1995, Adams et al. 2007). The high niche plasticity of Arctic charr also creates the fundamental basis for this thesis, as the niche use of populations as well as of individuals within them can be expected to reflect differences in food-web structures and prevailing competitive and predatory interactions within the fish communities.

What is the importance of phenotypic plasticity of Arctic charr from different ecological perspectives? For example, at the individual level, the ability to feed on various prey types and to live in different habitats facilitates adaptation to a fluctuating environment, including seasonal changes in light, temperature and available food (Power et al. 2008). At the population level, high niche plasticity maximizes the potential to use different food and habitat resources, while individual niche specialization within the populations alleviates intraspecific resource competition (Araujo et al. 2011, Bolnick et al. 2011). At the community level, phenotypic plasticity enables interspecific niche segregation that reduces competitive and predatory interactions between sympatric species (Vanni et al. 2009, Araùjo et al. 2011). Moreover, generalist foraging behaviour typically weakens interaction strengths between consumers and their prey and thereby increases food-web stability (Rooney \& McCann 2012). At the whole ecosystem level, generalist foraging across habitat boundaries is also important, as it may fundamentally affect the cycling of nutrients and energy (Polis et al. 1997, Vanni 2002). These examples demonstrate the potential fundamental role of Arctic charr in subarctic lake ecosystems and highlight the conservation status of the species.

Arctic charr can play a major role in food webs, especially in lakes situated at extreme latitudes and altitudes where no other fish species are present. However, the Arctic charr populations inhabiting lakes at lower latitudes and altitudes are particularly sensitive to global warming inducing changes in water temperature and quality as well as in fish community structure (e.g. Karlsson et al. 2009, Jeppesen et al. 2010, 2012). For example, cyprinids and percids have been observed to spread towards higher latitudes and altitudes and, together with reduced water quality, to threaten cold-adapted salmonids, including Arctic charr (e.g. Lehtonen 1996, Jeppesen et al. 2012). Similarly, introduction of whitefish (Coregonus lavaretus (L.)) and natural spread of pike (Esox lucius L.) have had detrimental consequences for native Arctic charr populations in 
northern Fennoscandia (Svärdson 1976, Byström et al. 2007). Potential future changes in ice-cover period and water colour may also have significant but complex impacts on the competitive interactions between Arctic charr and brown trout (Salmo trutta L.) (Finstad et al. 2011, Helland et al. 2011, Ulvan et al. 2012). Hence, understanding how Arctic charr and its sympatric resource competitors partition food and habitat resources is crucial for monitoring and managing subarctic lakes and their fish communities (Jeppesen et al. 2010, Hein et al. 2012). From the whole ecosystem perspective, it is also important to recognize how different biotic and abiotic factors, including intra- and interspecific interactions, seasonality and lake morphometry, can influence energy flow pathways in subarctic lakes.

\subsection{Study objectives}

The main aim of this thesis was to evaluate how different biotic and abiotic factors (e.g. intra- and interspecific resource competition, predation, seasonality and lake morphometry) influence the diet and habitat use of Arctic charr in subarctic lakes.

The main study hypotheses were:

1. Arctic charr undergo seasonal and ontogenetic shifts in diet depending on seasonal and size-related availability of different food resources (I, this synthesis).

2. Arctic charr show significant diet and habitat segregation with sympatric resource competitors including whitefish and grayling (Thymallus thymallus (L.)) (II), and brown trout (III).

3. Lake morphometry and fish species richness influence the relative reliance of Arctic charr on littoral and pelagic production (IV).

These hypotheses were studied by investigating the food-web structures and the diet and habitat use of fish in 17 subarctic lakes where Arctic charr was the dominant fish species or coexisted with several other fish species. Although there has been a long tradition in studying interspecific interactions between salmonid fish species in northern Scandinavia (e.g. Nilsson 1965, Svärdson 1976, Klemetsen et al. 2003), previous studies have mainly used traditional stomach contents and habitat analyses and thus have not been able to quantify the long-term relative contributions of littoral and pelagic trophic pathways in supporting top consumers in these oligotrophic lakes. To overcome and compensate for the methodological issues related to short-term habitat and diet analyses, this thesis uses results from stable carbon and nitrogen isotope analyses to evaluate longterm trophic niche of Arctic charr and of sympatric fish species. Moreover, from the whole ecosystem perspective, this thesis provides important information about the relative contributions of and coupling between littoral and pelagic food-web compartments in subarctic lakes. 
Although littoral production has been shown to be particularly high in clear water, oligotrophic, high-latitude lakes (e.g. Vadeboncoeur et al. 2003, Karlsson \& Byström 2005, Ask et al. 2009), pelagic production in these lakes may show a pulsed increase in the late open-water season (Rautio et al. 2000, Forsström et al. 2005) and zooplankton can then become a particularly profitable prey for Arctic charr due to their high lipid content (Syväranta \& Rautio 2010). The main aim of the first study (I) was to evaluate seasonal changes in the relative reliance of Arctic charr on littoral production in an oligotrophic subarctic lake, Saanajärvi, where only few brown trout coexist with abundant Arctic charr. As the predation risk and feeding efficiency can be strongly affected by individual size (e.g. Werner \& Gilliam 1984), Arctic charr in Saanajärvi were also expected to undergo ontogenetic dietary shifts. To evaluate the generality of the results from Saanajärvi, ontogenetic shifts in the long-term littoral reliance and trophic level of Arctic charr were also explored in the other 16 study lakes (this synthesis).

Arctic charr may have a particularly wide (i.e. generalist) trophic niche when it lives in allopatry or is the most abundant species in the fish community (e.g. Nilsson 1965, Amundsen 1995). However, Arctic charr may show restricted niche use when coexisting with abundant sympatric fish species such as whitefish or brown trout. Moreover, despite a wide trophic niche at the population level, individual Arctic charr may show highly specialized diets and habitats (e.g. Amundsen 1995, Bolnick et al. 2003). Consequently, the ability of Arctic charr populations and individuals to utilize different food and habitat resources can strongly depend on the prevailing inter- and intraspecific interactions. The main objective in II and III was to explore niche segregation between Arctic charr and its common sympatric resource competitors including whitefish and grayling (II), and brown trout (III). Interspecific niche segregation has been suggested to facilitate stable coexistence of sympatric species (cf. Hardin 1960, Nilsson 1965). The degree of intraspecific niche segregation between littoral and pelagic Arctic charr was also examined to evaluate potential impacts of individual specialization on habitat and food-web coupling (III).

Previous food web studies of high-latitude freshwaters have mostly been conducted in relatively small and shallow lakes and ponds, in which the entire bottom area can be illuminated and thus show high littoral primary and secondary production (Vadeboncoeur et al. 2003, Karlsson \& Byström 2005, Ask et al. 2009). However, pelagic production may make a substantial contribution to total production in large and deep lakes with limited littoral areas (e.g. Vadeboncoeur et al. 2008). The purpose of IV was to evaluate the extent to which lake morphometric characteristics (e.g. size, depth and shape) and fish species richness can be used to predict the relative reliance of Arctic charr on littoral production in 17 subarctic lakes. Arctic charr were expected to shift from a littoral to a more pelagic trophic niche and also to a higher trophic level in large lakes where strong interspecific competition for littoral resources and the availability of small planktivorous prey fish species (e.g. whitefish and vendace) may promote pelagic piscivorous foraging by Arctic charr. 


\section{MATERIAL AND METHODS}

\subsection{Study lakes}

The 17 study lakes are situated in the subarctic region of northern Fennoscandia (Fig. 3). Most lakes are oligotrophic and relatively clear, but cover a marked gradient in size $\left(0.5-1084 \mathrm{~km}^{2}\right)$, depth $\left(Z_{\max }=12-95 \mathrm{~m}\right)$ and altitude $(12-679 \mathrm{~m}$ a.s.l.) (Appendix $\mathrm{A}$ in IV). Saanajärvi and Gæsjavri are situated above the treeline, whereas the other study lakes are surrounded by birch (Betula spp.) or pine (Pinus sylvestris L.) forests. Small patches of farmland occur only in some of the lake catchments. The lakes are all dimictic and typically ice-free from June to October. The morphometric and limnological variables (Appendix A in IV) were measured during the field work or obtained from public databases and electronic maps maintained by Finnish (Lapland Centre for Economic Development, Transport and Environment, National Land Survey of Finland) and Norwegian environmental administrations. The relative depth ratios $\left(Z_{\mathrm{r}}\right)$ and shoreline development indices $(D)$ were calculated according to Wetzel (2001). To delimit the littoral, profundal and pelagic zones, the compensation depth (see Fig. 1) was measured in Finnish study lakes using LI-1400 light meter (Li-Cor Inc., USA; wavelength 400-700 nm). In these lakes, the compensation depth ranges from 4 to $16 \mathrm{~m}$, whereas the relative proportion of littoral zone to the whole lake surface area (estimated from bathymetric maps as the area delimited by the compensation depth contour) varies between 13-100 $\%$ (Appendix A in IV).

In addition to abiotic characteristics, the study lakes show marked differences in their fish communities, with the total number of fish species existing in a single lake ranging from 2 to 13 (Appendix A in IV). Moreover, the dominance of Arctic charr in the fish communities differed substantially among the study lakes. Arctic charr were most abundant in lakes where they coexisted solely with brown trout, or with whitefish and burbot (Lota lota (L.)) as was the case in Grsjavri (Appendix A in IV). Arctic charr made only a small contribution to the total fish catch in the largest Finnish study lakes, where 
coregonids were the dominant fish species. In some of these large Finnish lakes, whitefish has evolved into littoral, pelagic and profundal morphs, which have distinct trophic niches and morphometric characteristics (Harrod et al. 2010). A littoral and a profundal Arctic charr morph coexist in Fjellfrøsvatn (Amundsen et al. 2008), but only the identified littoral morphs were chosen for studies in this thesis (III, IV). In other study lakes Arctic charr occur as monomorphic populations. Vendace (Coregonus albula (L.)), land-locked salmon (Salmo salar m. sebago Girard), lake trout and common bullhead (Cottus cobio L.) have been introduced to some of these large Finnish lakes with multi-species fish communities. The native fish fauna in the lakes also include three-spined stickleback (Gasterosteus aculeatus L.), minnow (Phoxinus phoxinus (L.)), perch (Perca fluviatilis L.), pike, nine-spined stickleback (Pungitius pungitius (L.)), Atlantic salmon (Salmo salar L.), Alpine bullhead (Cottus poecilopus Heckel) and flounder (Platichthys flesus (L.)).

The lakes were sampled in 2005-2010. Saanajärvi was sampled in April, June and September 2006 (I), and again in January-February and August 2011 (IV, this synthesis). Due to limited resources, the other study lakes were sampled only once or twice during the late open-water season (between August and October), when the stable $\mathrm{C}$ and $\mathrm{N}$ isotopes in fish muscle tissue were expected to reflect the predominant food resources assimilated during the summer growth period (Perga \& Gerdeaux 2005).

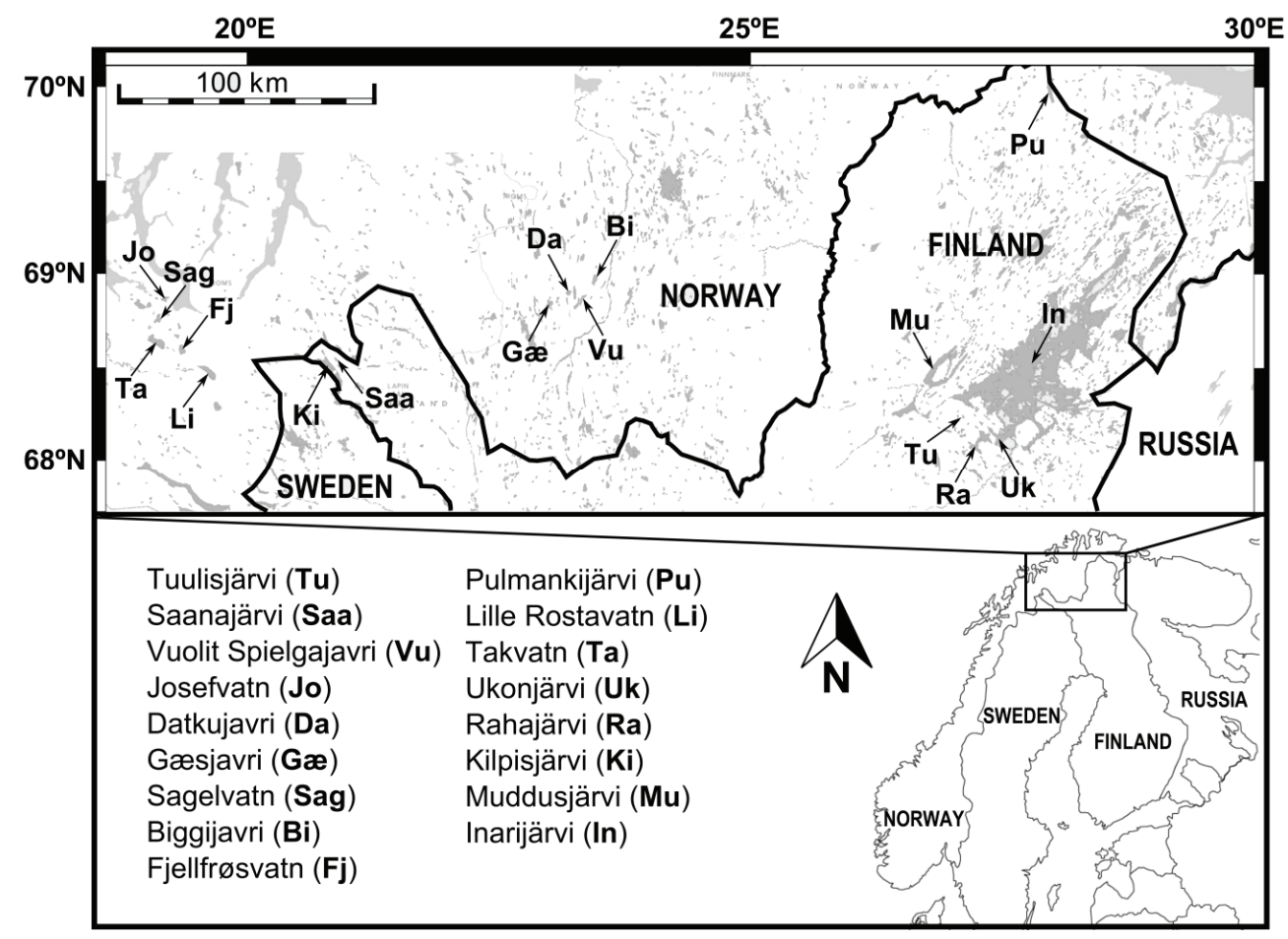

FIGURE 3 Location of the study lakes in northern Fennoscandia. 


\subsection{Sample collection and preparation}

\subsubsection{Zooplankton and benthic macroinvertebrates}

From each study lake, qualitative samples of zooplankton and benthic macroinvertebrates were collected for SIA. Zooplankton were sampled from the pelagic zone by taking several hauls throughout the water column with a 50$100 \mu \mathrm{m}$ mesh plankton net until sufficient material was obtained. The samples were sieved through a $100 \mu \mathrm{m}$ and a $200 \mu \mathrm{m}$ mesh to remove unwanted material and to separate adult cladocerans and copepods from juveniles and other small zooplankton including rotifers. When the amount and composition of the sample permitted, zooplankton were further manually separated to cladocerans and copepods.

Benthic macroinvertebrates were collected from the littoral (0-10 m depth) and profundal (15-40 $\mathrm{m}$ depth) zones using a kick net in the lake shore and an Ekman grab or a benthic sledge in the deep littoral and profundal areas. All benthic samples were first sieved through a $500 \mu \mathrm{m}$ mesh and in the laboratory the living macroinvertebrates were sorted from the bottom substrate, identified to species, genus or family level, and stored at $-20^{\circ} \mathrm{C}$ in separate sample vials. From molluscs, only the soft body tissue was prepared for later SIA.

\subsubsection{Fish}

Fish were sampled from the littoral, profundal and pelagic zones using 1.5-6.0 m high, 30-60 m long multi-mesh and standard gillnets with knot-to-knot mesh sizes ranging from 5 to $65 \mathrm{~mm}$. Gillnets were checked daily (after 10-12 h soak time) and usually set for a total of 3-10 nights in each lake. Catch per unit of effort (CPUE; number of fish $100 \mathrm{~m}^{-2}$ gillnet night ${ }^{-1}$ ) was only estimated from the multi-mesh gillnet catches (II, III). Fish were immediately killed and transported on ice to the field laboratory, where they were identified, measured (total or fork length, $\mathrm{mm}$ ) and weighed (fresh mass, g). Date and depth of capture as well as gillnet type and mesh size were also recorded. In Fjellfrøsvatn, profundal Arctic charr morphs were visually separated from normal littoral morphs (Amundsen et al. 2008). Some fish were dissected immediately, but most were instantly packed into marked plastic bags and frozen at $-20{ }^{\circ} \mathrm{C}$ until later analysis.

Further preparation of fish included: (1) removal of saggital otoliths for age and growth determination (I), (2) dissection of samples from muscle (I-IV) and liver tissues (I, this synthesis) for SIA, and (3) removal of stomachs for SCA (I-IV). For SCA (I-IV), the stomach fullness was visually estimated on a percentage scale ranging from empty $(0 \%)$ to full $(100 \%)$. The relative contribution of each prey taxon to the total stomach fullness was subsequently estimated according to Amundsen et al. (1996). Typical taxa found from lakes and fish stomach contents included: (1) zooplankton (Bosmina sp., Daphnia sp. and Holopedium gibberum Zaddach cladocerans; Bythotrephes longimanus Leydig and Polyphemus sp. predatory cladocerans; Eudiaptomus graciloides Liljeborg, 
Acanthocyclops sp., Megacyclops sp. and Cyclops spp. copepods), (2) molluscs (Lymnaea sp., Planorbidae and Valvatidae snails, Pisidium sp. and Sphaerium sp. mussels), (3) semi-benthic crustacea (Gammarus lacustris Sars amphipods, Asellus aquaticus L. isopods, Eurycercus sp. chydorids), (4) larvae and pupae of aquatic insects (Chironomidae, Trichoptera, Ephemeroptera, Dytiscidae and Megaloptera), and (5) fish (e.g. whitefish, vendace, three- and nine-spined stickleback, minnow, burbot and Arctic charr) (Fig. 4).

Schoener (1970) similarity index was used to estimate the habitat and diet overlap between fish species and populations (I, II, III). Levins' (1968) index was calculated to estimate dietary niche width of coexisting fish species (II, III) and of pelagic- and littoral-caught Arctic charr (III), whereas the prevalence of individual specialization within the populations was estimated according to Bolnick et al. (2002) (III).

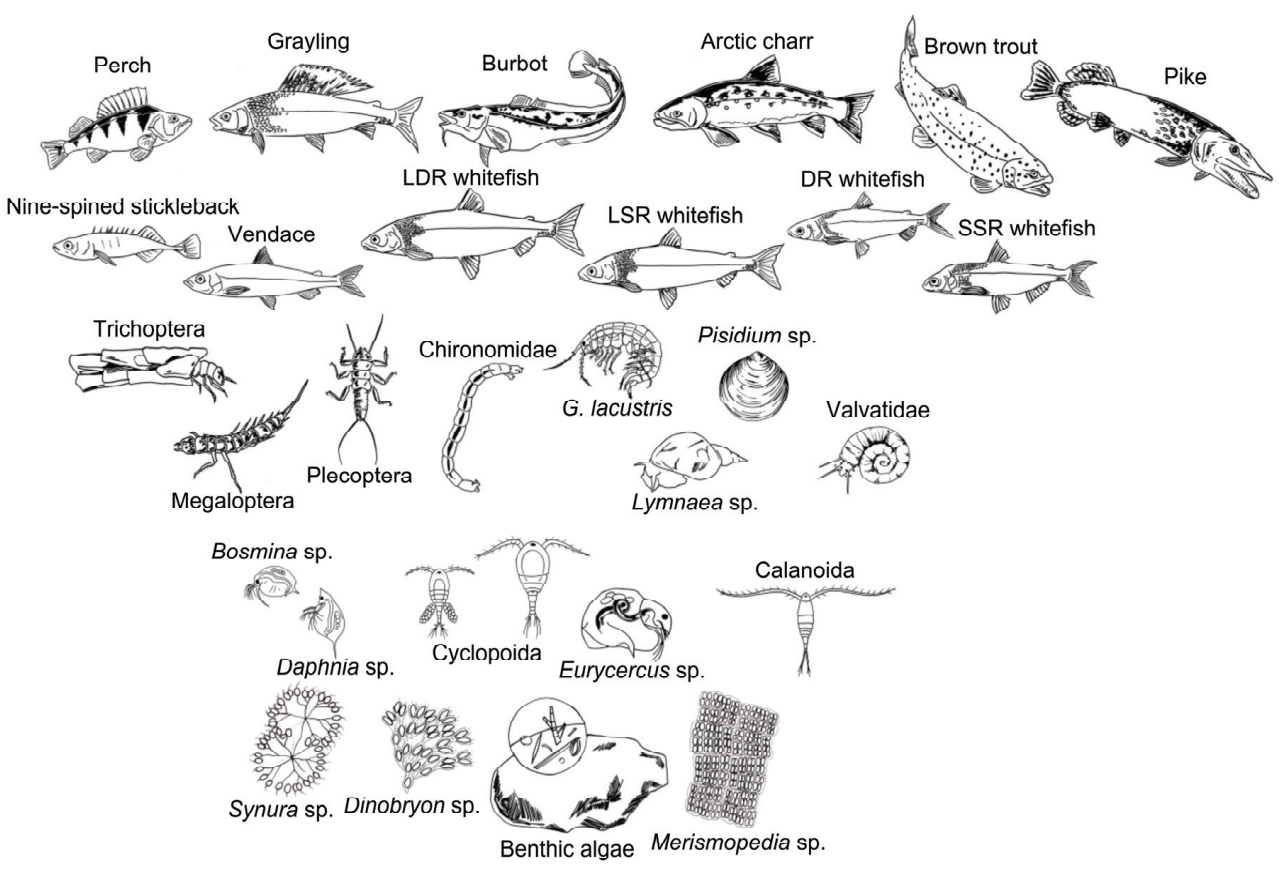

FIGURE 4 Some taxa commonly found in subarctic lakes of northern Fennoscandia. The organisms were drawn by Pekka Antti-Poika. See Harrod et al. (2010) for definition of the whitefish morphs.

\subsection{Data analyses}

\subsubsection{Stable isotope analyses}

The samples of zooplankton, benthic macroinvertebrates and fish prepared for SIA were stored at $-20^{\circ} \mathrm{C}$ before drying for about $48 \mathrm{~h}$ in a freeze-dryer or at 60 
${ }^{\circ} \mathrm{C}$ in an oven. The samples were finally ground into a homogeneous powder and weighed $(0.500-0.600 \mathrm{mg})$ for subsequent SIA conducted mainly using a FlashEA 1112 elemental analyser (Thermo Fisher Scientific Corporation, Waltham, MA, U.S.A.) coupled to a Thermo Finnigan DELTAplus Advantage mass spectrometer at the Aquatic Sciences laboratory, University of Jyväskylä. Stable $\mathrm{C}$ and $\mathrm{N}$ isotope ratios are expressed as delta values $\left(\delta^{13} \mathrm{C}\right.$ and $\delta^{15} \mathrm{~N}$, respectively) relative to the international standards for $C$ (Vienna PeeDee Belemnite) and N (atmospheric nitrogen) (see Fry 2006). Pike white muscle tissue with known isotopic composition was used as an internal working standard and inserted in each run after every 5 samples. Standard deviation of the internal standard was typically $<0.3 \%$ for $\delta^{13} \mathrm{C}$ and $<0.2 \%$ for $\delta^{15} \mathrm{~N}$.

The relative reliance of fish on littoral carbon sources was estimated either by using a linear two-source isotopic mixing model (Karlsson \& Byström 2005) (I, this synthesis) or the SIAR package (Stable Isotope Analysis in R; Parnell et al. 2010) (III, IV). SIAR uses a Bayesian approach to estimate dietary contributions and to consider uncertainties related to isotopic variability in consumers, food sources and trophic fractionation factors (Parnell et al. 2010). SIAR was also used to estimate relative contributions of putative littoral, pelagic, profundal and fish prey in the long-term diet of Arctic charr, whitefish and grayling (II). In addition, the mean trophic level of Arctic charr (fork length $\geq 150 \mathrm{~mm}$ ) in each study lake was estimated according to the mixing model of Karlsson \& Byström (2005) (IV, this synthesis). The littoral reliance (LR) (I, this synthesis) and trophic level (TL) estimates (IV, this synthesis) were calculated by comparing the mean stable $\mathrm{C}$ and $\mathrm{N}$ isotopic values from Arctic charr muscle $\left(\delta^{13} \mathrm{C}_{\text {charr }}, \delta{ }^{15} \mathrm{~N}_{\text {charr }}\right)$ with those from littoral $\left(\delta^{13} \mathrm{C}_{\text {lit }}, \delta{ }^{15} \mathrm{~N}_{\text {lit }}\right)$ and pelagic $\left(\delta^{13} \mathrm{C}_{\mathrm{pel}}\right.$, $\delta^{15} \mathrm{~N}_{\mathrm{pel}}$ ) primary consumers (Karlsson \& Byström 2005):

$$
\begin{aligned}
& L R=\left[\delta^{13} \mathrm{C}_{\text {charr }}-\delta^{13} \mathrm{C}_{\mathrm{pel}}-\left(\delta^{15} \mathrm{~N}_{\text {charr }}-\delta^{15} \mathrm{~N}_{\text {pel }}\right) T S\right]\left[(1-T S B S)\left(\delta^{13} \mathrm{C}_{\text {lit }}-\delta^{13} \mathrm{C}_{\mathrm{pel}}\right)^{-1}\right]^{-1} \\
& T L=2+\left(\left[\delta^{15} \mathrm{~N}_{\text {charr }}-\delta^{15} \mathrm{~N}_{\mathrm{pel}}-\left(\delta^{13} \mathrm{C}_{\text {lit }}-\delta^{13} \mathrm{C}_{\mathrm{pel}}\right) B S L R\right] \Delta_{\mathrm{N}}{ }^{-1}\right.
\end{aligned}
$$

where TS is the slope of the trophic fractionation of $C$ and $N\left(\Delta_{\mathrm{C}}: \Delta_{\mathrm{N}}\right)$ and $B S$ is the slope of the linear relationship between the pelagic and littoral baselines in each lake. The pelagic baselines were calculated as the mean $\pm \mathrm{SD} \delta^{13} \mathrm{C}$ and $\delta^{15} \mathrm{~N}$ values of all zooplankton samples, whereas the littoral baseline was calculated from those benthic macroinvertebrates collected from the littoral zone and observed in fish stomach contents (mainly snails, Gammarus lacustris and chironomid larvae) (I-IV). The commonly used trophic fractionation factors of $0.4-1.0 \%$ for $\delta^{13} \mathrm{C}$ and $3.3-3.5 \%$ for $\delta^{15} \mathrm{~N}$ were used (I-IV). Concentrations of C and $\mathrm{N}$ were also incorporated into the SIAR model (II-IV).

The variation in $\delta^{13} \mathrm{C}$ and $\delta^{15} \mathrm{~N}$ has commonly been used as a measure of isotopic (dietary) niche width of species, and also to estimate individual specialization within populations (Bearhop et al. 2004, Layman et al. 2012). The isotopic niche widths of Arctic charr, whitefish and grayling were calculated using the "adehabitat" package in $\mathrm{R}$ that bounds $95 \%$ of the individuals of each 
species in the $\delta^{13} \mathrm{C}-\delta^{15} \mathrm{~N}$ bi-plot space (II). The SIBER (Stable Isotope Bayesian Ellipses in R; Jackson et al. 2011) model was used in SIAR package to explore the isotopic niche widths of Arctic charr and brown trout populations (III). The standard ellipse areas are calculated using a Bayesian approach to correct for potentially biased estimates arising from different sample sizes (Jackson et al. 2011).

\subsubsection{Statistical analyses}

A pair-wise $t$-test was used to test differences in $\delta^{13} \mathrm{C}$ and $\delta^{15} \mathrm{~N}$ values between muscle and liver tissues from Saanajärvi Arctic charr (I). The non-parametric Kruskal-Wallis test followed by Mann-Whitney pair-wise comparisons were used to compare $\delta^{13} \mathrm{C}$ and $\delta^{15} \mathrm{~N}$ values among littoral, profundal and pelagic invertebrates and to test differences in littoral reliance estimates and $\delta^{15} \mathrm{~N}$ values between Arctic charr size groups and seasons (I). The same nonparametric tests were used to test seasonal differences in littoral reliance and trophic level of Arctic charr (this synthesis), and to test between-species and between-lake differences in fork length, and between-species differences in $\delta^{13} \mathrm{C}$ and $\delta 15 \mathrm{~N}$ values of Arctic charr, whitefish and grayling (II). The Mann-Whitney test was also used to test within-lake differences in fork length, individual specialization estimates, $\delta^{13} \mathrm{C}$ and $\delta^{15} \mathrm{~N}$ values of all Arctic charr and brown trout and of pelagic-caught and littoral-caught Arctic charr, except in a few cases when parametric $t$-test was used due to normality and homoscedasticity of the data (III). Linear regression (I) and Spearman correlation (this synthesis) were used to study ontogenetic shifts in Arctic charr littoral reliance $\left(\delta^{13} \mathrm{C}\right)$ and trophic level $\left(\delta^{15} \mathrm{~N}\right)$. A stepwise linear regression was used to examine relationships between mean littoral reliance and trophic level of Arctic charr and lake abiotic characteristics and fish species richness (IV). All statistical tests were conducted using SPSS versions 14.0-19.0 (SPSS Inc., Chicago, IL, USA). 


\section{RESULTS AND DISCUSSION}

\subsection{Seasonal and ontogenetic diet shifts}

Arctic charr in Saanajärvi were found to feed actively throughout the year as only a few individuals had empty stomachs (I). Both SCA and SIA showed that Arctic charr fed mainly on littoral benthic macroinvertebrates regardless of season. Chironomid larvae and Gammarus lacustris dominated the diet under the ice in April, while chironomid pupae and adult insects were important prey items in July, but were not observed in September when benthic macroinvertebrates were again the most abundant prey. The relative proportion of zooplankton increased slightly towards the end of open-water season, but overall made only a small contribution to the Arctic charr diet. The dominance of littoral food was confirmed by the high littoral reliance estimates derived from the $\delta^{13} \mathrm{C}$ values of Arctic charr muscle and liver tissues (mean \pm SD: $83 \pm 15 \%$ and $71 \pm 22 \%$, respectively). The strong littoral reliance was also largely independent of Arctic charr size (I). Only the medium-sized Arctic charr (200-350 mm) showed a slight shift towards a more pelagic diet in late open-water season as shown by the littoral reliance estimates derived from liver $\delta^{13} \mathrm{C}$. However, the muscle and liver $\delta^{15} \mathrm{~N}$ values indicated a significant ontogenetic shift to a higher trophic level with increasing total length. The results from SIA were confirmed by SCA demonstrating a cannibalistic diet for large $(>500 \mathrm{~mm})$ Arctic charr that had fed mainly on smaller $(150-190 \mathrm{~mm})$ conspecifics. This ontogenetic shift to cannibalism was associated with a marked increase in Arctic charr growth rate.

The results from 2006 (I) were supported by a later study conducted in Saanajärvi in January-February and August 2011 (Eloranta et al. 2013). At that time, the size distribution of Arctic charr differed markedly from that in 2006 including also individuals of length between 350-500 mm (Fig. 5). Nevertheless, Arctic charr showed a high littoral reliance (mean \pm SD $L R_{\text {muscle: }} 79 \pm 16 \%$; $L R_{\text {liver: }}$ : $69 \pm 23 \%)$ that was largely independent of season $(U=434-469, n=65-66, P>$ 0.10 ) or individual size (Fig. 5). The littoral reliance and trophic level estimates, derived from Arctic charr liver $\delta^{13} \mathrm{C}$ and $\delta^{15} \mathrm{~N}$ values respectively, indicated only 
slight shift to a more littoral diet (Fig. 5) and to a higher trophic level (Fig. 6) with increasing size.

The results from Saanajärvi demonstrate that in oligotrophic, subarctic lakes, top consumers like Arctic charr can rely strongly on littoral production regardless of season or size of individuals (I), and also from year to year (this synthesis). Besides their higher benthic primary production (Vadeboncoeur et al. 2003, 2008, Ask et al. 2009), littoral trophic pathways may also dominate the energy supply to top consumers due to the larger size of benthic macroinvertebrates relative to zooplankton making them generally more profitable prey (Karlsson \& Byström 2005, Vander Zanden et al. 2006). Despite minor seasonal and ontogenetic dietary shifts at the whole population level, individuals within the Saanajärvi Arctic charr population showed marked differences in short-term (SCA) and long-term (SIA) diets (I, Fig. 5 and 6). While most individuals fed mainly on littoral prey, some had exceptionally low $\delta^{13} \mathrm{C}$ values and/or large amounts of zooplankton in the stomach contents indicating specialization to a more pelagic trophic niche. The high prevalence for individual niche specialization observed in Saanajärvi, but also in Tuulisjärvi, Gaesjavri and Fjellfrøsvatn where Arctic charr were relatively abundant (Fig. 5), probably results from strong intraspecific competition for limited food resources as well as from high availability of open niches due to weak or absent interspecific competition with sympatric fish species (cf. Amundsen 1995, Araújo et al. 2011).

In Saanajärvi, the strong littoral reliance of small Arctic charr may also be associated with a limited access to zooplankton resources due to a high predation risk in the pelagic open-water habitat. Unlike small $(<200 \mathrm{~mm})$ conspecifics, larger Arctic charr may have escaped the predation window of cannibals and thus can undergo a temporary shift to a more pelagic diet and habitat in late open-water season (cf. L'Abée-Lund et al. 1993, Amundsen et al. 2008, Amundsen \& Knudsen 2009). This could also explain why pelagic-caught Arctic charr were on average larger than littoral-caught conspecifics in some other study lakes, where a few large piscivorous brown trout and Arctic charr were present (III). Besides the temporary increase in pelagic production, pelagic zooplankton may also become a profitable prey for Arctic charr in late openwater season when they are lipid-rich (Syväranta \& Rautio 2010, Mariash 2012) and thus may provide essential fatty acids supporting the overwintering and reproduction of Arctic charr. Preliminary data obtained from Saanajärvi in 2011 suggest that littoral and pelagic prey items can provide similar essential fatty acids, but pelagic zooplankton generally have higher concentrations of fatty acids compared to littoral benthic macroinvertebrates (Eloranta et al. 2013). However, a more specialized pelagic diet may also be detrimental for Arctic charr if it is associated with increased accumulation of trophically-transmitted parasites (e.g. Knudsen et al. 2011). For example, Arctic charr in Kilpisjärvi and Pulmankijärvi were highly parasitized by Diphyllobothrium ssp. cestodes and Echinorynchus ssp. acanthocephalans, which were derived from parasitized pelagic whitefish or Mysis spp. opossum shrimps, respectively, and could exceed a density of $>1000$ per individual Arctic charr. Hence, the diet and habitat use of top consumers in 
oligotrophic, subarctic lakes can be determined both by the prevailing predatorprey dynamics and by the seasonal and spatial differences in food quantity and quality (Table 1).

TABLE 1 Summary of the general characteristics of littoral, pelagic and profundal habitats and prey items in unproductive subarctic lakes. Fish typically show a more generalist foraging strategy in the littoral zone than in the more homogeneous pelagic and produndal zones, where the small and/or poorly detectable prey items often demand a specialized foraging strategy.

\begin{tabular}{llll}
\hline \hline & Littoral & Pelagic & Profundal \\
\hline Habitat characteristics & & & \\
Production & High & Low/Moderate & Low \\
Physical heterogeneity & High & Low & Low \\
Visibility & Moderate/High & High & Low \\
Resource competition & High & Low/Moderate & Low \\
Predation risk & Low/Moderate & High & Low \\
Prey characteristics & & & \\
Size & Large & Small & Moderate \\
Diversity & High & Low & Low \\
Lipid-content & Moderate & High & Moderate \\
Seasonal availability & Fairly constant & Variable & Fairly constant \\
Fish foraging strategy & Generalist & Specialist & Specialist \\
\hline \hline
\end{tabular}

Unlike in Saanajärvi (I), Arctic charr showed a significant ontogenetic shift from a pelagic to a more littoral diet with increasing size in some of the study lakes (Fig. 5). This ontogenetic niche shift often happened at the fork length of 200250 mm (see Gæsjavri, Lille Rostavatn and Takvatn in Fig. 5), when Arctic charr may have become competitively dominant (cf. Werner \& Gilliam 1984, Vanni et al. 2009) and/or escaped the predator window of littoral-dwelling piscivorous fish species or conspecifics (e.g. L'Abée-Lund et al. 1993, Amundsen \& Knudsen 2009). In some other study lakes, Arctic charr shifted from a littoral to a more pelagic diet with increasing size. According to SCA data from Kilpisjärvi and Inarijärvi, Arctic charr shifted from a generalist diet consisting of littoral macroinvertebrates and fish to a more specialized foraging on pelagic prey fish species including small whitefish and vendace. In contrast, the negative relationship between Arctic charr littoral reliance and size observed in Sagelvvatn was probably due to an ontogenetic shift from benthivorous to a more pelagic planktivorous niche promoted by reduced predation risk and 
strong interspecific competition for littoral resources with abundant brown trout (III).

In some study lakes, Arctic charr shifted to a higher trophic level with increasing size (Fig. 6). Such ontogenetic niche shifts were particularly evident in medium-sized and large lakes where small prey fish species such as threeand nine-spined stickebacks and/or pelagic whitefish were available for large piscivorous Arctic charr (IV, Fig. 6). Unlike in other lakes, Arctic charr in Josefvatn and Sagelvvatn showed a negative relationship between trophic level and size (Fig. 6). There, small Arctic charr apparently consumed profundal chironomids and/or predatory copepods that typically have markedly higher $\delta^{15} \mathrm{~N}$ values compared to most littoral macroinvertebrates and cladoceran zooplankton (III, see also I). A profundal benthivorous diet probably also explains the exceptionally high apparent trophic level of some small Arctic charr in Fjellfrøsvatn and Takvatn (Fig. 6).

These results demonstrate that top consumers in subarctic lakes can show marked ontogenetic shifts in littoral reliance and trophic level, and the trends in ontogenetic niche shifts can be highly variable depending on the prevailing competitive and predatory interactions within the fish communities. But how can these ontogenetic niche shifts by top consumers affect food-web dynamics? Firstly, ontogenetic niche shifts by generalist fish species can promote the coupling of littoral and pelagic habitats and food-web compartments in lakes (e.g. McIntyre et al. 2006). Secondly, the population size structure can modify the nature and strength of competitive and predatory interactions between fish species and between individuals within the species (Woodward et al. 2005, Miller \& Rudolf 2011). The intraspecific niche variation can alleviate intra- and interspecific resource competition, but also promote food-web stability by decreasing interaction strengths between consumers and prey resources (Bolnick et al. 2011, Miller \& Rudolf 2011, Kratina et al. 2012). 


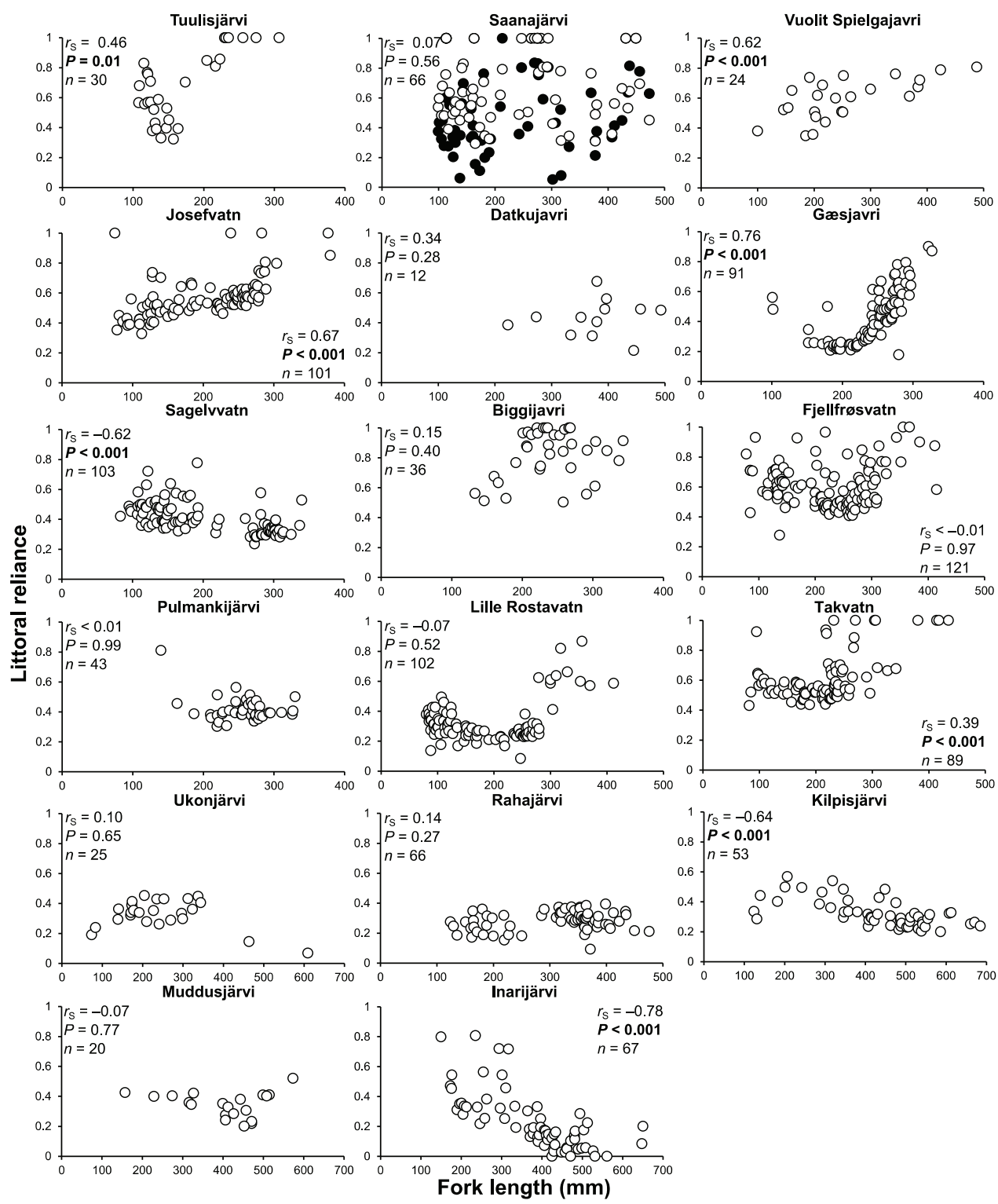

FIGURE 5 Relationship between littoral reliance [estimated according to Karlsson \& Byström (2005)] and fork length ( $\mathrm{mm}$ ) of Arctic charr caught from each study lake. Spearman correlation coefficients $\left(r_{\mathrm{S}}\right)$ and sample sizes $(n)$ are shown, and the statistically significant correlations $(P<0.05)$ are higlighted in bold. In the Saanajärvi figure, black dots stand for littoral reliance estimates that were derived from Arctic charr liver isotope values and were positively correlated with Arctic charr fork length $\left(r_{S}=0.22, n=65, P=0.08\right)$. 

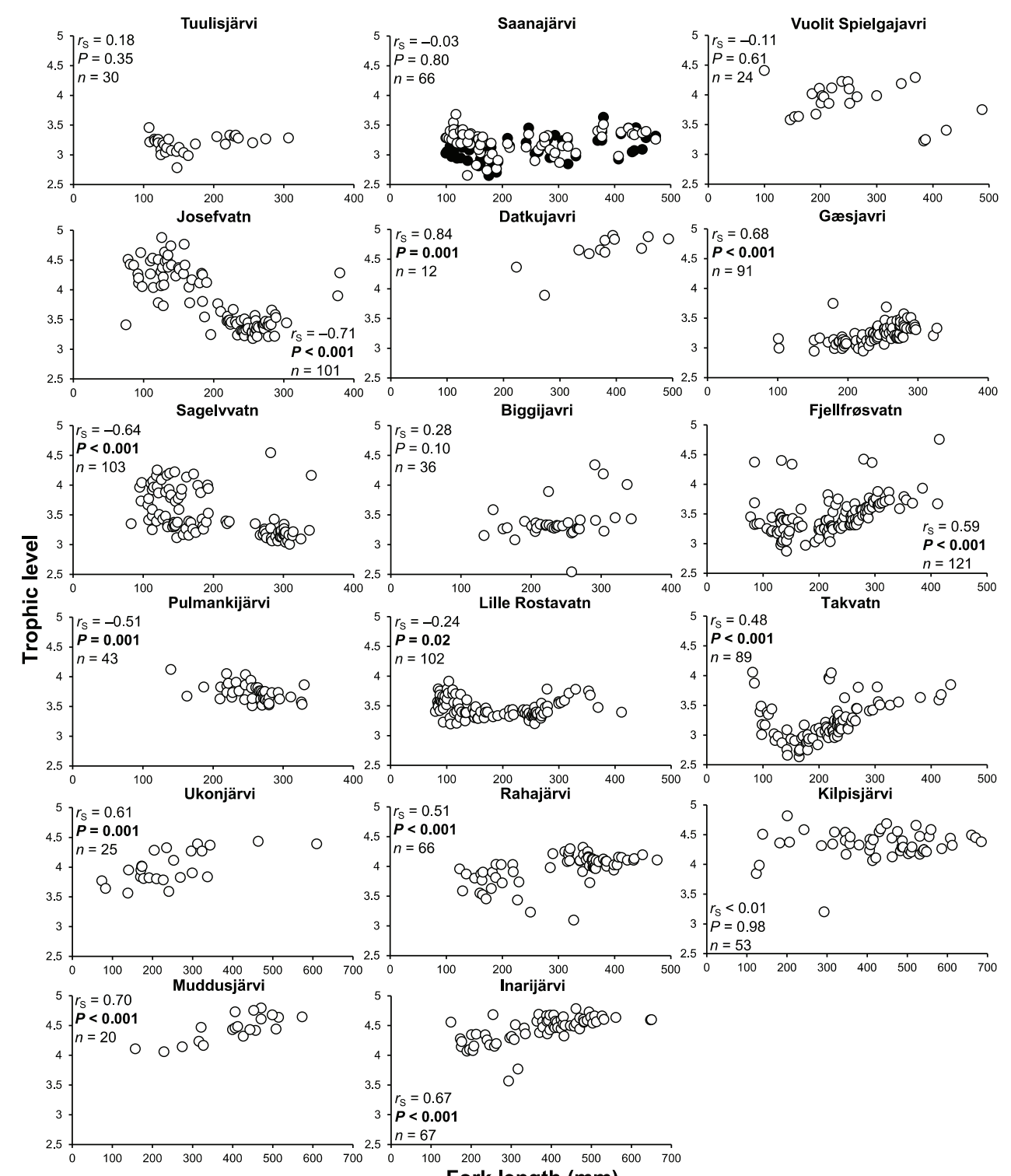

Fork length $(\mathrm{mm})$

FIGURE 6 Relationship between trophic level [estimated according to Karlsson \& Byström (2005)] and fork length (mm) of Arctic charr caught from each study lake. Spearman correlation coefficients $\left(r_{\mathrm{S}}\right)$ and sample sizes $(n)$ are shown, and the statistically significant correlations $(P<0.05)$ are higlighted in bold. In the Saanajärvi figure, black dots stand for trophic level estimates that were derived from Arctic charr liver isotope values and were positively correlated with Arctic charr fork length $\left(r_{\mathrm{S}}=0.31, n=65, P=0.01\right)$. 


\subsection{Inter- and intraspecific niche segregation}

\subsubsection{Arctic charr, whitefish and grayling}

Arctic charr generally showed higher niche plasticity than sympatric whitefish and grayling (II). Arctic charr showed marked between-lake and betweenindividual differences in diet and habitat use, whereas whitefish was mainly utilizing zooplankton and Eurycercus sp. chydorids, and grayling were feeding on littoral benthic prey in all the study lakes. Despite significant habitat overlap, the stomach contents and stable isotopes indicated significant diet segregation between Arctic charr and whitefish, particularly in Datkujavri where Arctic charr were significantly larger and fed mainly on smaller fish. In Vuolit Spielgajavri, where grayling were exceptionally abundant, whitefish mainly inhabited the profundal zone. In the deepest study lake Biggijavri, Arctic charr and grayling were almost equally abundant and shared the littoral trophic niche.

These results suggest that the high niche plasticity and, in particular, the potential piscivorous foraging of Arctic charr likely reduce competitive interactions with whitefish and thereby facilitate stable coexistence of the two fish species in lakes where their natural distributions overlap. Moreover, the existence of a third competing fish species in the littoral zone (grayling) may also reduce the competitive dominance of whitefish and thereby indirectly alleviate resource competition between Arctic charr and whitefish. Correspondingly, Sandlund et al. (2010) found that whitefish may not be competitively superior over Arctic charr if they have limited access to littoral resources due to existence of a strong littoral competitor (perch) or deterioration of littoral habitats due to lake regulation. In large and deep lakes, Arctic charr and whitefish can reduce competitive interactions by segregating into distinct profundal and littoral/pelagic trophic niches, respectively (Svärdson 1976, Sandlund et al. 2010). In large subarctic lakes, Arctic charr can shift to piscivory and thereby alleviate resource competition and reduce the abundance and dominance of smaller whitefish (Svärdson 1976, Kahilainen \& Lehtonen 2002). In contrast, introduced whitefish can have marked deleterious effects on native Arctic charr populations in small and shallow lakes that lack profundal refugia for Arctic charr (cf. Svärdson 1976, Sandlund et al. 2010). For example, the native Arctic charr population in small $\left(\right.$ area $\left.=0.44 \mathrm{~km}^{2}\right)$ and shallow $\left(Z_{\max }=6\right.$ m) Skaidijärvi, northeastern Finland, has undergone a serious decline since the introduction of whitefish a few decades ago (Nieminen 2012). Nowadays, the Arctic charr population is maintained by supplementary stocking of Arctic charr from nearby lakes and by intensive fishing of whitefish (Nieminen 2012; see also Museth et al. 2005).

The competitive dominance between Arctic charr and whitefish may also depend on the altitude and productivity of the lake. As in sympatry with brown trout (Finstad et al. 2011, Helland et al. 2011), Arctic charr seem to be competitively dominant over whitefish in cold, oligotrophic high-altitude lakes 
with elongated ice-cover period and limited pelagic production. This assumption is supported by recent laboratory experiments showing a higher survival and growth rate for Arctic charr reared at low temperatures (Siikavuopio et al. 2010), but also by present field data from Gæsjavri, where Arctic charr made around $65 \%$ of the total fish catch (Appendix A in IV) and also had a more pelagic trophic niche than whitefish (Fig. 2 in IV). Gæsjavri is situated near three other study lakes, where whitefish is more abundant than Arctic charr (II), but is a colder and more oligotrophic lake because of its location at a high altitude above the tree-line (Appendix A in IV). The long annual ice-cover period and limited pelagic production in Gaesjavri probably reduce the abundance and growth of whitefish, but at the same time promote the competitive dominance of Arctic charr with superior ability to feed in cold and dark conditions (e.g. Siikavuopio et al. 2010, Helland et al. 2011). Recent field data from Kilpisjärvi also demonstrates that large piscivorous Arctic charr can prey upon small pelagic whitefish throughout the winter (K.K. Kahilainen \& B. Hayden, University of Helsinki, unpublished data). An important question is whether the competitive interactions between Arctic charr and whitefish will change with ongoing climate warming.

\subsubsection{Arctic charr and brown trout}

As in sympatry with whitefish and grayling (II), Arctic charr generally showed more plastic habitat use and diet than the littoral-dwelling brown trout (III). However, brown trout showed a slightly higher prevalence for piscivory than Arctic charr. Despite partial habitat overlap (particularly in Sagelvvatn), the SCA and SIA data indicated a significant dietary segregation between the largely planktivorous Arctic charr and insectivorous brown trout in all five study lakes. In some populations, the wide dietary niche of Arctic charr was evidently due to specialization of individuals to predominantly littoral, pelagic and/or profundal niches. In general, pelagic-caught Arctic charr showed lower reliance on littoral energy sources and less individual variation in stomach contents and stable isotope values than the littoral-caught conspecifics. However, the level of inter- and intraspecific niche segregation showed between-lake differences probably due to differences in prevailing competitive interactions within the fish communities. For example, despite significant habitat overlap, Arctic charr and brown trout showed marked segregation into planktivorous and benthivorous diets in Sagelvvatn, where brown trout were relatively abundant. This interspecific niche segregation led to a significant intraspecific dietary overlap between the pelagic- and littoral-caught Arctic charr as indicated by SCA and SIA. In contrast, Arctic charr were relatively more abundant than brown trout in Fjellfrøsvatn and thus able to utilize the littoral habitat and food resources unlike in Josefvatn and Lille Rostavatn, where the littoral niche was dominated by brown trout or other littoral fish species.

The results indicate that interspecific resource competition may induce a pelagic niche shift by top consumers, such as Arctic charr, in subarctic lakes. 
Correspondingly, lake trout have been demonstrated to shift to a more pelagic planktivorous niche when competing for littoral resources with invasive bass (Centrarchidae) species in Canadian temperate lakes (Vander Zanden et al. 1999a). Hence, despite potentially high littoral production in clear, oligotrophic high-latitude lakes (e.g. Vadeboncoeur et al. 2003, Karlsson \& Byström 2005), top consumers may need to alter their foraging behaviour and shift from the littoral to a more pelagic diet when coexisting with strong resource competitors (e.g. Nilsson 1965). The generally lower littoral reliance of Arctic charr may, however, also be related to the greater size and depth of the present study lakes than in the previously studied high-latitude lakes (Sierszen et al. 2003, Karlsson \& Byström 2005, IV). Moreover, by forcing Arctic charr to a more pelagic niche in summer (cf. Nilsson 1965, Amundsen \& Knudsen 2009), brown trout may actually indirectly increase coupling between littoral and pelagic habitats and food webs in subarctic lakes although the species itself mainly utilizes the littoral niche. Previous studies suggest that the competitive dominance between Arctic charr and brown trout may depend on season and lake productivity. For example, Arctic charr can dominate the littoral resources in winter (Amundsen \& Knudsen 2009), and has also superior ability to feed and grow in dark and cold conditions (Elliott 2011, Helland et al. 2011). Consequently, Arctic charr have probably outcompeted brown trout from the most unproductive highaltitude lakes (Finstad et al. 2011). Despite increasing knowledge about competitive interactions between Arctic charr and brown trout (Finstad et al. 2011, Helland et al. 2011, Ulvan et al. 2012), more research is still needed to predict and assess the potential impacts of climate warming on fish communities and, in particular, on food-web dynamics in subarctic lakes (Jeppesen et al. 2010, Hein et al. 2012).

The SCA and SIA data indicated high individual variation in Arctic charr short- and long-term diets, respectively. Moreover, in some of the study lakes, the pelagic- and littoral-caught Arctic charr showed partial intraspecific niche segregation. The relatively specialized planktivorous niche of pelagic-caught Arctic charr likely reflects the homogeneity of available food resources (e.g. Schindler \& Scheuerell 2002) and the higher foraging efficiency of specialized individuals (e.g. Schluter 1996, Bolnick et al. 2003), but may also significantly constrain benthic-pelagic coupling in subarctic lakes (cf. Quevedo et al. 2009). However, the SIA data suggested that the pelagic- and littoral-caught Arctic charr relied on both littoral and pelagic energy sources and thus did not show absolute long-term niche segregation. The general niche plasticity of Arctic charr is probably an important adaptation to seasonal fluctuations in food, light and temperature. Arctic charr have been shown to utilize almost exclusively the littoral habitat and food sources from early winter to late spring (Amundsen et al. 2008, Amundsen \& Knudsen 2009). Thus, in August, the muscle isotope values of pelagic-caught Arctic charr may still partly reflect the probable spring-time benthivorous diet (Perga \& Gerdeaux 2005). The partial reliance of pelagic-caught Arctic charr on littoral food resources may also result from foraging on adult and pupal stages of aquatic insects, such as littoral and/or 
profundal chironomids (Amundsen et al. 2008, Amundsen \& Knudsen 2009). This observation demonstrates that the pelagic Arctic charr can also be subsidized by littoral and profundal benthic resources (cf. Schindler \& Scheuerell 2002, Wagner et al. 2012).

The present results also support the argument that generalist fish populations can be heterogeneous sets of specialized individuals (cf. Bolnick et al. 2007). Individual specialization to littoral and pelagic niches is relatively common among postglacial fishes (e.g. Schluter 1996) and thus may constrain food-web coupling, as demonstrated for pelagic and littoral perch in a Swedish temperate lake (Quevedo et al. 2009). When possible, generalist fish should thus not be treated as functionally equivalent units in lake ecosystems, because individual differences in niche use can have significant implications for foodweb dynamics (e.g. Jansson et al. 2007, Miller \& Rudolf 2011, Thompson et al. 2012) as well as for incipient speciation (Bolnick et al. 2003, Araújo et al. 2011).

\subsection{Lake morphometry, fish species richness and Arctic charr diet}

Arctic charr gained on average 50:50 \% of their carbon from littoral and pelagic sources, but the lake-specific mean littoral reliance estimates ranged from 30 to $82 \%$ in the 17 study lakes (IV). The Arctic charr littoral reliance estimates showed a significant negative relationship with increasing lake surface area and fish species richness. This pattern was supported by SCA data showing a significant decrease in the relative proportion of benthic macroinvertebrates in Arctic charr stomach contents with increasing lake size and fish species richness. Similarly, the mean trophic level of Arctic charr $(3.8 \pm 0.6)$ showed marked differences between the study lakes (range 3.2-5.1), and was positively correlated with lake relative depth (measured as a ratio between lake area and maximum depth; see Wetzel 2001) and with fish species richness. These results from SIA were supported by SCA data showing a significant increase in the relative proportion of fish (mainly pelagic whitefish and vendace) in Arctic charr stomach contents in large, but relatively shallow lakes with multi-species fish communities.

This study indicates that, in nutrient-poor subarctic lakes, the relative importance of littoral and pelagic trophic pathways for energy supply to top consumers is largely determined by lake size associated with increased fish species richness. Littoral production has been shown to dominate primary production (Vadeboncoeur et al. 2003, 2008, Ask et al. 2009) and energy supply to higher consumers (Sierszen et al. 2003, Karlsson \& Byström 2005) in small, oligotrophic, clear-water high-latitude lakes. However, the present results demonstrate that generalist top consumers such as Arctic charr may rely significantly more on pelagic energy sources in larger subarctic lakes with extensive pelagic zones. Previous stable isotope studies have shown that the relative contribution of littoral and pelagic zones to whole-lake primary and secondary production can be determined by the lake morphometric and 
limnological characteristics (Vadeboncoeur et al. 2008, Dolson et al. 2009, Karlsson et al. 2009). The relative contribution of littoral production has been shown to decrease with increasing concentration of nutrients (e.g. Libourissen \& Jeppesen 2003, Vadeboncoeur et al. 2003) or coloured terrestrial organic matter in water (Karlsson et al. 2009) and with increasing lake depth and size (Vadeboncoeur et al. 2002, 2008). Dolson et al. (2009) argued that lake shape can also strongly regulate the availability of littoral habitat and food resources for cold-adapted top consumers (i.e. lake trout). However, all the present study lakes have relatively nutrient-poor, clear and cool water and thus the production and availability of littoral food resources is unlikely to be limited by water quality or temperature. Instead, the existence of several sympatric fish species in large subarctic lakes, including potential prey fish species in the pelagic zone and resource competitors and predators in the littoral zone, evidently promote the specialization of Arctic charr to a more pelagic, piscivorous trophic niche. Also the availability of profitable pelagic invertebrate prey, such as Mysis spp. predatory crustaceans in Pulmankijärvi, may facilitate the pelagic trophic niche of Arctic charr. While the pelagic niche specialization by Arctic charr probably constrains food-web coupling in large lakes, the flexible foraging on littoral and pelagic invertebrates probably increases food-web coupling in small and medium-sized lakes (cf. Schindler \& Scheuerell 2002).

Consistent with previous studies (Vander Zanden et al. 1999b, Post et al. $2000 \mathrm{~b}$ ), the results also suggest that food-chain length in subarctic lakes can be determined by ecosystem size rather than productivity. The increase in foodchain length is probably due to addition of intermediate consumers (here pelagic prey fish species) between the primary and top consumers in large lakes with higher species richness (cf. Vander Zanden et al. 1999b, Post et al. 2000b, Post 2002, Post \& Takimoto 2007). The pronounced decrease in Arctic charr omnivory observed in large subarctic lakes may be due to increased habitat heterogeneity (indicated by high shoreline complexity; see Appendix A in IV) and refugia for prey fish species that likely increases the density of preferred prey fish and thereby also promotes the piscivorous foraging by Arctic charr (cf. Post et al. 2000b). However, further empirical evidence is needed to recognize the linkages between ecosystem size, species diversity and prey preference by top consumers on food-web stability in subarctic lakes (Post et al. 2000a, Rooney \& McCann 2012).

\subsection{Limitations and proposals for future studies}

This thesis provides novel insights into the structure and dynamics of food webs in subarctic lakes. However, some aspects could have been improved if time, money and labour resources would have permitted. One apparent issue is that seasonal changes in Arctic charr diet were only studied in Saanajärvi. In other study lakes, competitive and predatory interactions between sympatric fish species could have induced stronger or different seasonal changes in Arctic 
charr niche use. Moreover, despite apparent methodological challenges, seasonal changes in availability of littoral and pelagic food resources could have been estimated to evaluate the adaptive and selective foraging behaviour of Arctic charr.

This thesis lacks data on very small, young-of-the-year (YOY) Arctic charr that are difficult, if not impossible, to sample using gillnets (cf. Finstad et al. 2000, Klemetsen et al. 2003). However, the inter- and intraspecfic feeding interactions in the critical early stages of Arctic charr may be important in determining the subsequent abundance and size structure of populations, as well as their resource use (e.g. Byström et al. 2004, Byström \& Andersson 2005, Byström 2006). In future studies, electrofishing and/or traps (cf. Byström 2006) could be used for collecting and analysing the density and diet of YOY Arctic charr in subarctic lakes with contrasting fish community compositions and morphometric characteristics.

This thesis used stable carbon isotopes to evaluate the relative contributions of littoral and pelagic production to Arctic charr energy supply. However, consumers in lakes can also derive some of their energy from allochthonous terrestrial carbon (e.g. Jansson et al. 2007, Ask et al. 2009, Solomon et al. 2011). The drawback in analysing only carbon and nitrogen stable isotopes is that these elements cannot reliably distinguish between the pelagic and terrestrial carbon sources (Pace et al. 2004). To overcome this methodological issue, limnologists have started to use e.g. whole-lake ${ }^{13} \mathrm{C}$ additions (e.g. Pace et al. 2004) and hydrogen stable isotopes (Solomon et al. 2011) to quantify the terrestrial resource use in lakes. In the future, similar study approaches could be used for evaluation of littoral, pelagic and terrestrial contributions to production and energy flow to top consumers in subarctic lakes.

Individual niche specialization should optimally be studied by collecting repeated observations on individuals over time (Araújo et al. 2011). However, such a sampling procedure is rarely possible and thus concurrent use of SCA and SIA has commonly been recognized as a good alternative approach (Layman et al. 2012). Although SIA can provide important information about the long-term niche use of fish populations and individuals within them, the method has several limitations (Layman et al. 2012). For example, consumers and their food sources may show substantial temporal and spatial variation in isotopic compositions (Syväranta et al. 2006). Consequently, samples for SIA should optimally be collected from different sites and at different times. However, limited resources together with the large number of study lakes prevented such a comprehensive field work in most of the lakes. To distinguish the effects of biotic and abiotic factors, the niche use and littoral reliance of Arctic charr could have been estimated in lakes that have all allopatric Arctic charr populations with similar size structures but show contrasting morphometric characteristics. Overall, more comprehensive studies focusing on the quantitative and qualitative differences between benthic and pelagic organisms and food-web compartments would provide valuable insights to production and functioning of subarctic lake ecosystems. 


\section{CONCLUSIONS}

The results of this thesis give strong evidence that the littoral and pelagic habitats and food-web compartments in subarctic lakes can be highly integrated by generalist top consumers. Arctic charr showed high plasticity in habitat use and diet, which evidently reflected between-lake differences in fish community compositions, food-web structures and in littoral and pelagic production. Overall, the generalist trophic niche of Arctic charr reduces competitive interactions between sympatric fish species as well as between individuals within the populations (Vanni et al. 2009), but is also an important adaptation to the seasonally fluctuating environment (Power et al. 2008). The results also highlight that generalist fish populations may not be homogeneous sets of individuals, but consist of specialized individuals with different food and habitat preferences (cf. Bolnick et al. 2003, Araújo et al. 2011). These individual differences in niche use may result from strong intraspecific resource competition, but also reflect size-related differences in predation risk and feeding efficiency inducing ontogenetic niche shifts (Werner \& Gilliam 1984). Hence, to understand energy flow pathways and predator-prey dynamics in lakes, it is crucial to recognize both littoral and pelagic food-web compartments and to examine the niche use of top consumers both at the individual and population levels. Such a comprehensive view of food-web structures is fundamental for predicting the responses of fish communities and subarctic lake ecosystems to potential environmental changes (e.g. Schindler \& Smol 2006, Jeppesen et al. 2010).

The results from Saanajärvi show that fish top consumers in clear water, oligotrophic subarctic lakes can strongly rely on littoral production regardless of season or individual size, and also from year to year. However, when other fish species are present, top consumers may shift to a more pelagic and/or to a specialized piscivorous trophic niche and thereby reduce competitive as well as predatory interactions with sympatric fish species (Fig. 7). Arctic charr were found to rely substantially less on littoral food resources when living in sympatry with abundant littoral-dwelling brown trout (III) than when dominating the fish community (I). When efficient planktivorous (whitefish) and benthivorous (grayling) competitors were present, Arctic charr used different kinds of 


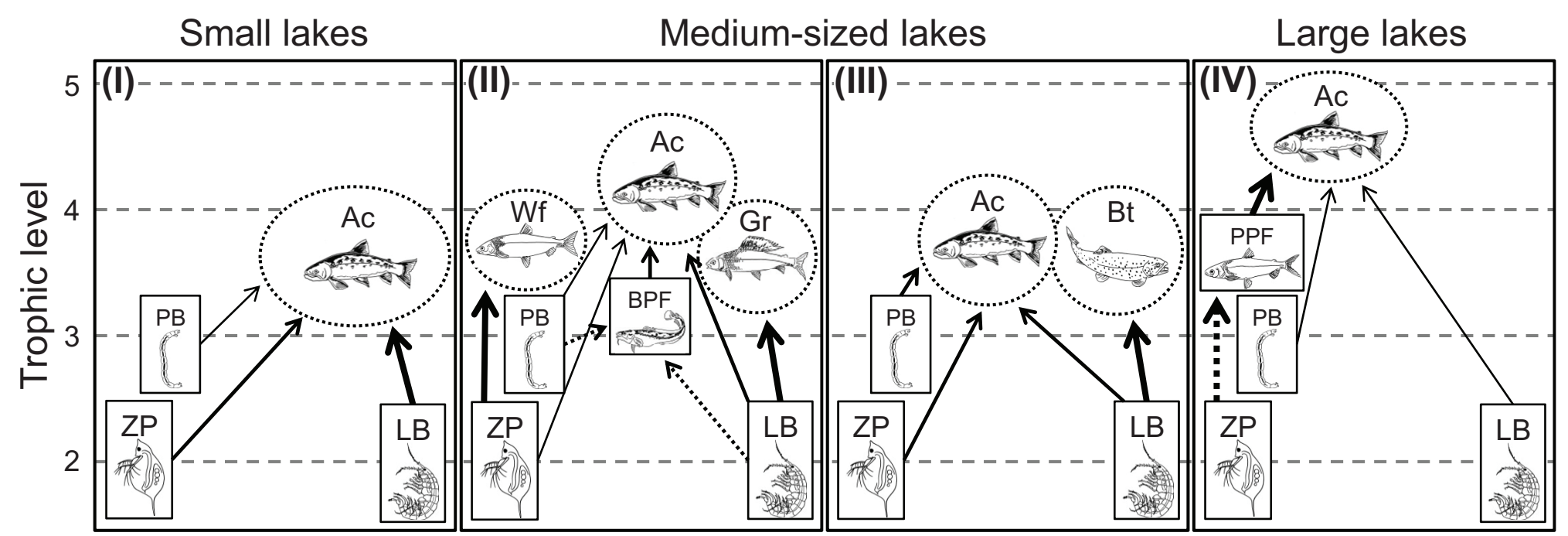

Pelagic $\langle\ldots \ldots \ldots . . . . .>$ Littoral

FIGURE 7 Schematic illustration of the variable position of Arctic charr in subarctic lake food webs. (I) In small and/or shallow lakes, Arctic charr (Ac) dominate the fish community and mainly consume littoral benthic macroinvertebrates (LB), although individuals within the populations can show distinct, specialized niches. (II) In lakes where planktivorous whitefish (Wf) and benthivorous grayling (Gr) are abundant, Arctic charr show high niche plasticity, but can feed to a great extent on small benthivorous prey fish species (BPF). (III) When coexisting with littoral-dwelling brown trout (Bt), Arctic charr shift to feed more on pelagic zooplankton (ZP) and also on profundal benthic macroinvertebrates (PB). (IV) In large lakes with multi-species fish communities, Arctic charr can shift to a predominantly pelagic, piscivorous niche by feeding on small planktivorous prey fish species (PPF), in particular coregonids. Hence, Arctic charr evidently shift from a littoral benthic to a more pelagic trophic niche in large lakes, where the high availability of pelagic food and habitat resources together with intense interspecific resource competition and predation pressure in the littoral zone probably promote pelagic piscivorous foraging. The boxes and ellipses indicate the putative food sources and the trophic niches of sympatric fish species, respectively, and the arrows indicate the trophic links of different strengths. The organisms were drawn by Pekka Antti-Poika. The Roman numerals are corresponding to the situations described in I-IV. 
habitats and prey types, including smaller fish, and showed marked betweenlake and between-individual differences in diet (II). Hence, the food-web structures and energy flow pathways supporting top consumers in subarctic lakes can strongly depend on prevailing competitive and predatory interactions between sympatric fish species. Although it is difficult to predict what kind of impacts potential changes in lake productivity and fish community compositions will have on the present Arctic charr populations (e.g. Maitland 1995, Jeppesen et al. 2010, Hein et al. 2012), it can be expected that the marked niche plasticity of the species should promote adaptation to these environmental changes.

This thesis work gives valuable information about the food-web structures and energy flow pathways in relatively little studied subarctic lakes. Unlike in the more frequently studied small, shallow high-latitude lakes that show particularly high benthic production (e.g. Vadeboncoeur et al. 2003, Karlsson \& Byström 2005), pelagic phytoplankton-based production was shown to make a substantial contribution to energy supply for top consumers in larger subarctic lakes. In these lakes, small planktivorous prey fish (e.g. pelagic whitefish and vendace) can act as important trophic links between zooplankton and piscivorous top consumers. The addition of intermediate consumers between primary and top consumers also led to increased food-chain length as shown by the generally higher trophic level of Arctic charr in large study lakes. These potential between-lake differences in littoral-pelagic contributions and foodchain lengths should be borne in mind when planning management of subarctic lakes and fish communities, because they can have a fundamental role in ecosystem energetics and food-web stability (e.g. Schindler \& Scheuerell 2002, Vander Zanden \& Vadeboncoeur 2002, Rooney \& McCann 2012).

This thesis focused on subarctic lakes that have relatively simple communities and low primary production. However, the importance of a heterogeneous littoral zone for production and biodiversity, as well as the major role of generalist top consumers as integrators of littoral and pelagic food-web compartments, has also been demonstrated for temperate and tropical lakes (e.g. Hecky \& Hesslein 1995, Vander Zanden \& Vadeboncoeur 2002). One apparent latitudinal difference is that fish species in subarctic/Arctic lakes do not consume plant material like some fish species in more vegetated temperate and tropical lakes do (Jeppesen et al. 2010, Gonzáles-Bergonzoni et al. 2012). Low-latitude lakes are also older ecosystems and subjected to less pronounced seasonal fluctuations in light, temperature and productivity, which has facilitated the development of diverse invertebrate and fish communities. In contrast, the low species diversity in high-latitude lakes has promoted incipient speciation of some post-glacial fishes to various ecological niches (Schluter 1996). Thus, a single fish species, such as Arctic charr or whitefish, can act as several species and thus have a fundamental and complex influence on the structure and function of food webs in subarctic lakes. 
Acknowledgements

I am most indebted to my supervisors Prof. Roger Jones and Dr Kimmo Kahilainen for all their help and support during my ontogeny as a scientist. Roger has an incredible talent to encourage and guide when urgent help is needed, while otherwise giving the freedom for independent thinking and progression. His lessons and scientific work have been one of the principal sources of my inspiration from the very beginning I started my studies in Jyväskylä. To date I have not met as enthusiastic scientist working on fish ecology as Kimmo; I really appreciate his passion on underwater life and cannot imagine any better company during the several weeks of 24/7 field work we had up in the North. As long as the boat floats, only the sky sets the limits to you!

I want to thank all fellow students, teachers and researchers at our department for support and hilarious company during these years. You guys have been dragging me up from the mud when the science has felt pointless. I am also grateful to all people from Helsinki, Jyväskylä, Inari, Kilpisjärvi and Tromsø who have helped in the tremendous field and laboratory work. Pekka Antti-Poika earns special thanks for his fantastic drawings presented in this thesis. My dear main collaborators, Prof. Per-Arne Amundsen and Prof. Rune Knudsen, have had a major role in developing ideas and keeping up the good spirit. This thesis would never have been accomplished without these fantastic guys. I also want to thank the editor, Dr Timo Marjomäki, and the pre-examiners of this thesis, Dr Anders Finstad and Dr Jorma Piironen, for their valuable work.

Life is not only work and science, and the best ideas are often created during or after spending some quality spare time. I want to thank my dear friends outside the university, Matti, Tero, Lasse and Janne to mention but a few, for all their support and lovable company. Our fishing and hiking trips have been amazing and refreshing including a lot of fun and a some kind of mysterious spirituality; these shared moments in a boat, sauna or up on the fells have reminded me about the ultimate meaning of life. Finally, I want to thank my family, mum, dad, Hanna, Minna and Maikki, for being supportive and loving. Life has become more and more hectic every year, but you are always in my mind and in my heart wherever I am going. I want to thank Hanna-Kaisa for her encouragement and giving me a good reason to stop working and go home for a delicious dinner. I am also grateful to my uncle Anssi for waking up the Lapland madness and Arctic charr fanatic in me; you also had a crucial role in bringing me to study biology in Jyväskylä.

I want to thank the University of Jyväskylä for providing high-quality education and facilities during all my years as a M. Sc. and Ph. D. student. I am also thankful to the Kilpisjärvi Biological Station and the Muddusjärvi Research Station for acting at times as my "second home" during the field work. I am deeply grateful to the main funders, the Jenny and Antti Wihuri Foundation, the Ella and Georg Ehrnrooth Foundation and the Ellen and Artturi Nyyssönen Foundation, for making this thesis project possible. The travel grants kindly provided by the Fisheries Society of the British Isles, the University of Jyväskylä, 
the Biological Interactions Graduate School and the Finnish Union of Environmental Professionals enabled the expansion of my consciousness and international networks outside Fennoscandia. 


\section{YHTEENVETO (RÉSUMÉ IN FINNISH)}

\section{Nieriän vaihteleva asema subarktisten järvien ravintoverkoissa}

Nieriä on maailman pohjoisin makeanveden kalalaji ja siten tärkeä ravinnonlähde pohjoisten alueiden asukkaille, mutta myös merkittävä laji kylmien ja niukkatuottoisten subarktisten ja arktisten järviekosysteemien toiminnan kannalta. Monipuolisen ravinnonkäyttönsä ansiosta nieriä pystyy säätelemään sekä järven ulappa- eli pelagiaalivyöhykkeellä elävien planktisten eliöiden että ranta- eli litoraalivyöhykkeellä ja syvänne- eli profundaalivyöhykkeellä elävien pohjaeläinten runsautta ja lajikoostumusta. Näin ollen nieriän ravintoon ja elinpaikkaan vaikuttavien tekijöiden tunteminen on erittäin tärkeää tarkasteltaessa mahdollisten ympäristömuutosten vaikutuksia pohjoisten järviekosysteemien rakenteeseen ja toimintaan. Tässä väitöskirjassa tutkittiin, miten erilaiset elolliset (kilpailu ja saalistus lajien välillä ja sisällä) sekä elottomat ympäristötekijät (mm. vuodenajat sekä järven pinta-ala ja syvyys) vaikuttavat nieriän ravinnonkäyttöön subarktisissa järvissä. Aineistoa kerättiin yhteensä 17:sta PohjoisSuomessa ja Pohjois-Norjassa sijaitsevasta järvestä, jotka vaihtelivat niin pintaalan (0,5-1084 km²) kuin kalalajien lukumäärän (2-13) suhteen. Kalojen ravinnonkäyttöä sekä järvien ravintoverkkorakenteita tutkittiin perinteisen syönnösanalyysin lisäksi hiilen ja typen vakaiden isotooppien analyysilla, joka kuvastaa eri eliölajien ja -yksilöiden pitkän aikavälin energialähteitä ja kuluttajatasoa järven ravintoverkoissa. Järvien ravintoverkot jaetaan yleensä ulappavyöhykeen eli pelagiaalin (kasviplankton-eläinplankton-planktonsyöjäkala-petokala) ja rantavyöhykeen eli litoraalin (pohjalevä-pohjaeläin-pohjaeläinsyöjäkala-petokala) ravintoverkkoihin. Nämä ravintoverkot ovat tyypillisesti sidoksissa toisiinsa, sillä kalat kuten nieriät voivat käyttää sekä litoraalin että pelagiaalin ravintokohteita. Miten litoraalin ja pelagiaalin ravintoverkkojen merkitys järven kokonaistuotannossa ja kalojen ravinnonlähteenä riippuu järven elottomista ja elollisista ominaispiirteistä, on tärkeä tieto niin pohjoisten kalakantojen hoidon kuin näiden niukkatuottoisten järvien ekosysteemin tuntemisen kannalta.

Väitöskirjan ensimmäisen osatyön (I) tarkoituksena oli selvittää, miten nieriän ravinnonlähteet muuttuvat eri vuodenaikoina ja kalan kasvaessa. Tulokset osoittivat, että Saanajärven nieriäpopulaatio saa suurimman osan ravinnostaan litoraalin pohjalevien ja pohjaeläinten tuotannon kautta vuodenajasta tai kalan koosta riippumatta. Isotooppianalyysin tulosten perusteella nieriäyksilöiden välillä on kuitenkin suurta vaihtelua ravinnonkäytössä, mikä on todennäköisesti seurausta voimakkaasta lajinsisäisestä ravintokilpailusta. Ainoastaan keskikokoiset nieriät, jotka eivät oletettavasti olleet enää alttiita suurten kannibaalinieriöiden saalistukselle, kykenivät käyttämään loppukesällä runsastuneita pelagiaalin eläinplanktonresursseja. Nämä tulokset osoittavat, että litoraalin tuotantoketjut voivat olla huippupetojen kuten nieriän tärkein energialähde kirkkaissa ja niukkatuottoisissa subarktisissa järvissä. Litoraalin tuotanto voi olla sen sijaan vähäisempää eteläisemmissä järvissä, joissa runsas kasviplank- 
tontuotanto ja/tai valuma-alueelta tulevat humusaineet voivat estää pohjalevien fotosynteesiä.

Perustuotannon lisäksi kalojen ravinnonkäyttöä voi rajoittaa merkittävästi lajienvälinen sekä lajinsisäinen ravintokilpailu ja saalistus. Toinen osatyö (II) tarkasteli, miten nieriän, siian ja harjuksen ravinnon- ja elinympäristön käyttö eroaa kolmessa Pohjois-Norjassa sijaitsevassa järvessä, joissa lajien luontaiset levinneisyysalueet kohtaavat. Tulokset osoittivat, että nieriä pystyy käyttämään hyvin monipuolista ravintoa ja järven kaikkia eri habitaatteja, kun taas siika syö lähinnä eläinplanktonia ja harjus litoraalin pohjaeläimiä. Nieriän ravintonäytteet ja vakaiden isotooppien arvot osoittivat, että ravinnonkäytössä on suurta yksilöiden välistä vaihtelua osan käyttäessä myös pienempiä kaloja ravintonaan. Tulokset viittaavat siihen, että nieriän monipuolinen ja mukautuva ravinnonkäyttö on tärkeä tekijä, joka edesauttaa lajin säilymistä kilpailevien kalalajien, kuten siian, kanssa. Siika saattaa kuitenkin uhata hyvin pienten ja matalien järvien nieriäkantoja, sillä rajalliset ravinto- ja elinpaikkaresurssit voivat estää lajien ekologisten lokeroiden eriytymisen. Mahdolliset muutokset siikojen sekä muiden kalalajien runsauksissa ja levinneisyysalueissa voivatkin aiheuttaa merkittäviä muutoksia herkkien nieriäkantojen ja tunturijärvien eliöyhteisöjen hyvinvoinnille.

Väitöskirjan kolmas osatyö (III) tutki, miten lajienvälinen ja lajinsisäinen ekologisten lokeroiden eriytyminen voi rajoittaa litoraalin ja pelagiaalin ravintoverkkojen välistä sidonnaisuutta. Tätä havainnoitiin viidessä Pohjois-Norjassa sijaitsevassa järvessä, joissa nieriä ja taimen esiintyvät runsaimpina kalalajeina. Ravintonäytteet ja isotooppianalyysit osoittivat, että taimen käytti lähinnä litoraalin pohjaeläinravintoa, kun taas nieriä käytti järven kaikkia eri habitaatteja, mutta söi etupäässä pelagiaalin eläinplanktonia. Tulokset osoittivat, että välttääkseen kilpailua taimenen kanssa nieriä siirtyy syömään pelagiaalin eläinplanktonia ja saa siten huomattavasti pienemmän osan energiastaan litoraalin ravintoverkkojen kautta kuin järvissä, joissa se elää ainoana kalalajina tai yhdessä kymmenpiikin kanssa. Lajien ekologisten lokeroiden eriytyminen vaikutti riippuvan kalayhteisössä vallitsevan kilpailun voimakkuudesta ja luonteesta. Osassa tutkimusjärvistä, joissa nieriä esiintyi suhteessa runsaampana kuin taimen, näiden lajien elinpaikat ja ravinnonkäyttö olivat hyvin päällekkäisiä, kun taas järvissä, joissa taimen oli runsaslukuinen, lajien elinpaikat ja ravinnot olivat selvästi eriytyneet. Isotooppianalyysin tulokset osoittivat myös, että osassa tutkimusjärvistä litoraalista ja pelagiaalista pyydettyjen nieriöiden pitkän ajan ravinnonkäytöt erosivat merkitsevästi toisistaan. Pelagiaalin nieriöiden ravinto ja isotooppiarvot vaihtelivat hyvin vähän yksilöiden välillä, mikä viittaa erikoistuneeseen planktonsyöntiin, kun taas litoraalista pyydetyistä nieriöistä osa oli erikoistunut pohjaeläin- ja osa eläinplankton- tai kalaravintoon. Tulokset osoittavat, että nieriäyksilöillä voi olla hyvin erilaiset ravinnonkäyttöstrategiat ja tämä yksilöllinen erikoistuminen voi osaltaan rajoittaa järven ravintoverkkojen sidonnaisuutta.

Järven tuotanto ja ravintoverkkorakenteet riippuvat huomattavasti järven elottomista ominaispiirteistä. Väitöskirjan neljännen osatyön (IV) tavoitteena oli 
selvittää, miten järven morfologia (mm. pinta-ala ja syvyys), veden laatu ja kalalajien lukumäärä vaikuttavat nieriän energialähteeseen sekä trofia- eli kuluttajatasoon subarktisissa järvissä. Ravinto- ja isotooppianalyysit osoittivat, että nieriät käyttivät kaikissa tutkimusjärvissä sekä litoraalin että pelagiaalin energialähteitä, mutta siirtyivät yhä pelagisempaan ja petomaisempaan ravintoon järven koon ja kalalajien lukumäärän kasvaessa. Tutkimustulokset osoittavat, että vaikka litoraalin ravintoverkko voi olla erityisen tärkeä energialähde pienissä ja matalissa tunturijärvissä ja -lammissa, kasviplanktoniin perustuva pelaginen tuotanto on huomattavasti merkittävämpää suurissa järvissä, joissa litoraalivyöhykkeen suhteellinen osuus on pienempi ja kalalajien välinen saalistus sekä kilpailu litoraalin ravintoresursseista voi olla voimakasta. Nämä seikat on tärkeä huomioida pohjoisten järvien tilaa seurattaessa ja kalakantoja hoidettaessa, sillä energiankulkuun ja ravintoverkkorakenteisiin vaikuttavat tekijät määräävät pitkälti koko järven ekosysteemin toiminnan ja alttiuden mahdollisille ympäristömuutoksille. 


\section{REFERENCES}

Adams C.E. \& Maitland P.S. 2007. Arctic charr in Britain and Ireland - 15 species or one? Ecol. Freshwat. Fish 16: 20-28.

Adams C.E., Bean C.W., Fraser D. \& Maitland P.S. 2007. Conservation and management of the Arctic charr: a forward view. Ecol. Freshwat. Fish 16: 2-5.

Amundsen P.-A. 1994. Piscivory and cannibalism in Arctic charr. J. Fish Biol. 45: 181-189.

Amundsen P.-A. 1995. Feeding strategy of Arctic charr (Salvelinus alpinus): general opportunist, but individual specialist. Nord. J. Freshwat. Res. 71: 150156.

Amundsen P.-A. \& Knudsen R. 2009. Winter ecology of Arctic charr (Salvelinus alpinus) and brown trout (Salmo trutta) in a subarctic lake, Norway. Aquat. Ecol. 43: 765-775.

Amundsen P.-A., Gabler H.-M. \& Staldvik F.J. 1996. A new approach to graphical analysis of feeding strategy from stomach contents data - modification of the Costello (1990) method. J. Fish Biol. 48: 607-614.

Amundsen P.-A., Knudsen R. \& Klemetsen A. 2008. Seasonal and ontogenetic variations in resource use of two sympatric Arctic charr morphs. Environ. Biol. Fishes 83: 45-56.

Araújo M.S., Bolnick D.I. \& Layman C.A. 2011. The ecological causes of individual specialization. Ecol. Lett. 14: 948-958.

Ask J., Karlsson J., Persson L., Ask P., Byström P. \& Jansson M. 2009. Whole-lake estimates of carbon flux through algae and bacteria in benthic and pelagic habitat of clear-water lakes. Ecology 90: 1923-1932.

Bearhop S., Adams C.E., Waldron S., Fuller R.A. \& Macleod H. 2004. Determining trophic niche width: a novel approach using stable isotope analysis. J. Anim. Ecol. 73: 1007-1012.

Bolnick D.I., Svanbäck R., Araújo M.S. \& Persson L. 2007. Comparative support for the niche variation hypothesis that more generalized populations also are more heterogeneous. Proc. Natl. Acad. Sci. USA 104: 10075-10079.

Bolnick D.I., Yang L.H., Fordyce J.A., Davis J.M. \& Svanbäck R. 2002. Measuring individual-level resource specialization. Ecology 83: 2936-2941.

Bolnick D.I., Svanbäck R., Fordyce J.A., Yang L.H., Davis J.M., Hulsey C.D. \& Forister M.L. 2003. The ecology of individuals: incidence and implications of individual specialization. Am. Nat. 161: 1-28.

Bolnick D.I., Amarasekare P., Araújo M.S., Bürger R., Levine J.M., Novak M., Rudolf V.H.W., Schreiber S.J., Urban M.C. \& Vasseur D.A. 2011. Why intraspecific trait variation matters in community ecology? Trends Ecol. Evol. 26: 183-192.

Byström P. 2006. Recruitment pulses induce cannibalistic giants in Arctic char. J. Anim. Ecol. 75: 434-444. 
Byström P. \& Andersson J. 2005. Size-dependent foraging capacities and intercohort competition in an ontogenetic omnivore (Arctic char). Oikos 110: 523-536.

Byström P., Andersson J., Persson L. \& De Roos A.M. 2004. Size-dependent resource limitation and foraging-predation risk trade-offs: growth and habitat use in young arctic char. Oikos 104: 109-121.

Byström P., Karlsson J., Nilsson P., Van Kooten T., Ask J. \& Olofsson F. 2007. Substitution of top predators: effects of pike invasion in a subarctic lake. Freshwat. Biol. 52: 1271-1280.

Carpenter S.R., Kitchell J.F., Hodgson J.R., Cohran P.A., Elser J.J., Elser M.M., Lodge D.M., Kretchmer D., He X. \& Ende C.N. 1987. Regulation of lake primary productivity by food web structure. Ecology 68: 1863-1876.

Christoffersen K.S., Jeppesen E., Moorhead D.L. \& Tranvik L.J. 2008. Food-web relationships and community structures in high-latitude lakes. In: Vincent W.F. \& Laybourn-Parry J. (eds), Polar lakes and rivers: limnology of Arctic and Antarctic aquatic ecosystems, Oxford University Press, pp. 269-289.

Dolson R., McCann K., Rooney N. \& Ridgeway M. 2009. Lake morphometry predicts the degree of habitat coupling by a mobile predator. Oikos 118: 1230-1238.

Elliott J.M. 2011. A comparative study of the relationship between light intensity and feeding ability in brown trout (Salmo trutta) and Arctic charr (Salvelinus alpinus). Freshwat. Biol. 56: 1932-1972.

Eloranta A.P., Mariash H., Rautio M. \& Power M. 2013. Lipid rich zooplankton as a subsidy to the benthivorous winter diet of Arctic charr (Salvelinus alpinus) in a Finnish subarctic lake. Submitted manuscript.

Finstad A.G., Jansen P.A. \& Langeland A. 2000. Gillnet selectivity and size and age structure of an alpine Arctic char (Salvelinus alpinus) population. Can. J. Fish. Aquat. Sci. 57: 1718-1727.

Finstad A.G., Forseth T., Jonsson B., Bellier E., Hesthagen T., Jensen A.J., Hessen D.O. \& Foldvik A. 2011. Competitive exclusion along climate gradients: energy efficiency influences the distribution of two salmonid fishes. Glob. Change Biol. 17: 1703-1711.

Forsström L. 2006. Phytoplankton ecology of subarctic lakes in Finnish Lapland. Kilpisjärvi Notes 19: 1-42.

Forsström L., Sorvari S., Korhola A. \& Rautio M. 2005. Seasonality of phytoplankton in subarctic Lake Saanajärvi in NW Finnish Lapland. Polar Biol. 28: 846-861.

Fry B. 2006. Stable isotope ecology. Springer Science+Business Media, LLC, New York.

Gonzáles-Bergonzoni I., Meerhoff M., Davidson T.A., Teixeira-de Mello F., Baattrup-Pedersen A. \& Jeppesen E. 2012. Meta-analysis shows a consistent and strong latitudinal pattern in fish omnivory across ecosystems. Ecosystems 15: 492-503.

Hardin G. 1960. The competitive exclusion principle. Science 131: 292-297. 
Harrod C., Mallela J. \& Kahilainen K.K. 2010. Phenotype-environment correlations in a putative whitefish adaptive radiation. J. Anim. Ecol. 79: 1057-1068.

Hecky R.E. \& Hesslein R.H. 1995. Contributions of benthic algae to lake food webs as revealed by stable isotope analysis. J. N. Am. Benthol. Soc. 14: 631653.

Hein C.L., Öhlund G \& Englund G. 2012. Future distribution of Arctic char Salvelinus alpinus in Sweden under climate change: effects of temperature, lake size and species interactions. Ambio 41: 303-312.

Helland I.P., Finstad A.G., Forseth T., Hesthagen T. \& Ugedal O. 2011. Ice-cover effects on competitive interactions between two fish species. J. Anim. Ecol. 80: 539-547.

Jackson A.L., Inger R., Parnell A.C. \& Bearhop S. 2011. Comparing isotopic niche widths among and within communities: SIBER - Stable Isotope Bayesian Ellipses in R. J. Anim. Ecol. 80: 595-602.

Jansson M., Persson L., De Roos A.M., Jones R.I. \& Tranvik L.J. 2007. Terrestrial carbon and intraspecific size-variation shape lake ecosystems. Trends Ecol. Evol. 22: 316-322.

Jeppesen E., Meerhoff M., Holmgren K., Gonzáles-Bergonzoni I., Teixeira-de Mello F., Declerck S.A.J., De Meester L., Søndergaard M., Lauridsen T.L., Bjerring R., Conde-Porcuna J.M., Mazzeo N., Iglesias C., Reizenstein M., Malmquist H.J., Liu Z., Balayla D. \& Lazzaro X. 2010. Impacts of climate warming on lake fish community structure and potential effects on ecosystem function. Hydrobiologia 646: 73-90.

Jeppesen E., Mehner T., Winfield I.J., Kangur K., Sarvala J., Gerdeaux D., Rask M., Malmquist H.J., Holmgren K., Volta P., Romo S., Eckmann R., Sandström A., Blanco S., Kangur A., Ragnarsson Stabo H., Tarvainen M., Ventelä A.-M., Søndergaard M., Lauridsen T.L. \& Meerhoff M. 2012. Impacts of climate warming on the long-term dynamics of key fish species in 24 European lakes. Hydrobiologia 694: 1-39.

Jonsson B. \& Jonsson N. 2001. Polymorphism and speciation in Arctic charr. J. Fish Biol. 58: 605-638.

Kahilainen K. \& Lehtonen H. 2002. Brown trout (Salmo trutta L.) and Arctic charr (Salvelinus alpinus (L.)) as predators on three sympatric whitefish (Coregonus lavaretus (L.)) forms in the subarctic Lake Muddusjärvi. Ecol. Freshwat. Fish 11: 158-167.

Kalff J. 2002. Limnology: inland water ecosystems. Prentice-Hall, Inc., Upper Saddle River.

Karlsson J. \& Byström P. 2005. Littoral energy mobilization dominates energy supply for top consumers in subarctic lakes. Limnol. Oceanogr. 50: 538-543.

Karlsson J. \& Säwström C. 2009. Benthic algae can support zooplankton growth during winter in a clear-water lake. Oikos 118: 539-544.

Karlsson J., Byström P., Ask J., Ask P., Persson L. \& Jansson M. 2009. Light limitation of nutrient-poor lake ecosystems. Nature 460: 506-510. 
Klemetsen A. 2010. The charr problem revisited: exceptional phenotypic plasticity promotes ecological speciation in postglacial lakes. Freshwat. Rev. 3: 49-74.

Klemetsen A., Amundsen P.-A., Dempson J.B., Jonsson B., Jonsson N., O'Conell M.F.O. \& Mortensen E. 2003. Atlantic salmon Salmo salar L., brown trout Salmo trutta L. and Arctic charr Salvelinus alpinus (L.): a review of aspects of their life histories. Ecol. Freshwat. Fish 12: 1-59.

Knudsen R., Siwertsson A., Adams C.E., Garduño-Paz M., Newton J. \& Amundsen P.-A. 2011. Temporal stability of niche use exposes sympatric Arctic charr to alternative selection pressures. Evol. Ecol. 25: 589-604.

Kratina P., LeCraw R.M., Ingram T. \& Arnholt B.R. 2012. Stability and persistence of food webs with omnivory: is there a general pattern? Ecosphere 3: 1-18.

L'Abée-Lund J.H., Langeland A., Jonsson B. \& Ugedal O. 1993. Spatial segregation by age and size in Arctic charr: a trade-off between feeding possibility and risk of predation. J. Anim. Ecol. 62: 160-168.

Layman C.A., Araújo M.S., Boucek R., Hammerschlag-Peyer C.M., Harrison E., Jud Z.R., Matich P., Rosenblatt A.E., Vaudo J.J., Yeager L.A., Post D.M. \& Bearhop S. 2012. Applying stable isotope to examine food-web structure: an overview of analytical tools. Biol. Rev. 87: 545-562.

Lehtonen H. 1996. Potential effects of global warming on northern European freshwater fish and fisheries. Fisheries Manag. Ecol. 3: 59-71.

Levins R. 1968. Evolution in changing environments: some theoretical explorations. Princeton University Press, New Jersey.

Liboriussen L. \& Jeppesen E. 2003. Temporal dynamics in epipelic, pelagic and epiphytic algal production in a clear and a turbid shallow lake. Freshwat. Biol. 48: 418-431.

Lindeman R. L. 1942. The trophic-dynamic aspect of ecology. Ecology 23: 399417.

Maitland P.S. 1995. World status and conservation of the Arctic charr Salvelinus alpinus (L.). Nordic J. Freshw. Res. 71: 113-127.

Mariash H. 2012. Seasonal feeding strategies of subarctic zooplankton. Jyväskylä Studies in Biological and Environmental Science 241: 1-37.

McIntyre J.K., Beauchamp D.A., Mazur M.M. \& Overman N.C. 2006. Ontogenetic trophic interactions and benthopelagic coupling in Lake Washington: evidence from stable isotopes and diet analysis. Trans. Am. Fish. Soc. 135: 1312-1328.

Miller T.E.X. \& Rudolf H.W. 2011. Thinking inside the box: community-level consequences of stage-structured populations. Trends Ecol. Evol. 26: 457-466.

Museth J., Sandlund O.T. \& Borgstrøm R. 2005. Coexistence between introduced whitefish (Coregonus lavaretus) and native Arctic charr (Salvelinus alpinus) depends on heavy whitefish exploitation. Advanc. Limnol. 60: 343-350.

Nieminen P. 2012. Trophic niche of Arctic charr (Salvelinus alpinus) coexisting with lake trout (Salvelinus namaycush) and European whitefish (Coregonus lavaretus) in two divergent subarctic lakes. M. Sc. thesis, University of Jyväskylä, Jyväskylä. 
Nilsson N.-A. 1965. Food segregation between salmonid species in North Sweden. Inst. Freshw. Res., Drottningholm 2: 58-78.

Pace M.L., Cole J.J., Carpenter S.R., Kitchell J.F., Hodgson J.R., Van de Bogert M.C., Bade D.L., Kritzberg E.S. \& Bastviken D. 2004. Whole-lake carbon-13 additions reveal terrestrial support of aquatic food webs. Nature 427: 240243.

Parnell A.C., Inger R., Bearhop S. \& Jackson A.L. 2010. Source partitioning using stable isotopes: coping with too much variation. PLoS ONE 5: e9672.

Perga M.-E. \& Gerdeaux D. 2005. 'Are fish what they eat' all year round? Oecologia 144: 598-606.

Polis G.A. \& Strong D.R. 1996. Food web complexity and community dynamics. Am. Nat. 147: 813-846.

Polis G.A., Anderson W.B. \& Holt R.D. 1997. Toward an integration of landscape and food web ecology: the dynamics of spatially subsidized food webs. Annu. Rev. Ecol. Syst. 28: 289-316.

Post D. 2002. Using stable isotopes to estimate trophic position: models, methods, and assumptions. Ecology 83: 703-718.

Post D.M. \& Takimoto G. 2007. Proximate structural mechanisms for variation in food-chain length. Oikos 116: 775-782.

Post D.M., Conners M.E. \& Goldberg D.S. 2000a. Prey preference by a top predator and the stability of linked food chains. Ecology 81: 8-14.

Post D.M., Pace M.L. \& Hairston Jr N.G. 2000b. Ecosystem size determines foodchain length in lakes. Nature 405: 1047-1049.

Power M., Reist J.D. \& Dempson J.B. 2008. Fish in high-latitude Arctic lakes. In: Vincent W.F. \& Laybourn-Parry J. (eds), Polar lakes and rivers: limnology of Arctic and Antarctic aquatic ecosystems, Oxford University Press, pp. 249-268.

Quevedo M, Svanbäck R. \& Eklöv P. 2009. Intrapopulation niche partitioning in a generalist predator limits food web connectivity. Ecology 90: 2263-2274.

Rautio M. \& Vincent W.F. 2006. Benthic and pelagic food resources for zooplankton in shallow highlatidude lakes and ponds. Freshwat. Biol. 51: 1038-1052.

Rautio M., Sorvari S. \& Korhola A. 2000. Diatom and crustacean zooplankton communities, their seasonal variability and representation in the sediments of subarctic Lake Saanajärvi. J. Limnol. 59: 81-96.

Riget F., Jeppesen E., Landkildehus F., Lauridsen T.L., Geertz-Hansen P., Christoffersen K. \& Sparholt H. 2000. Landlocked Arctic charr (Salvelinus alpinus) population structure and lake morphometry in Greenland - is there a connection? Polar Biol. 23: 550-558.

Rooney N. \& McCann K.S. 2012. Integrating food web diversity, structure and stability. Trends Ecol. Evol. 27: 40-46.

Sadro S., Melack J.M. \& MacIntyre S. 2011. Spatial and temporal variability in the ecosystem metabolism of a high-elevation lake: integrating benthic and pelagic habitats. Ecosystems 14: 1123-1140.

Sandlund O.T., Museth J., Næsje T.F., Rognerud S., Saksgård R., Hesthagen T. \& Borgstrøm R. 2010. Habitat use and diet of sympatric Arctic charr 
(Salvelinus alpinus) and whitefish (Coregonus lavaretus) in five lakes in southern Norway: not only interspecific population dominance? Hydrobiologia 650: 27-41.

Schindler D.E. \& Scheuerell M.D. 2002. Habitat coupling in lake ecosystems. Oikos 98: 177-189.

Schindler D.W. \& Smol J.P. 2006. Cumulative effects of climate warming and other human activities on freshwaters of Arctic and subarctic North America. Ambio 35: 160-168.

Schluter D. 1996. Ecological speciation in postglacial fishes. Phil. Trans. R. Soc. Lond. B. 351: 807-814.

Schoener T.W. 1970. Nonsynchronous spatial overlap of lizards in patchy habitats. Ecology 51: 408-418.

Sierszen M.E., McDonald M.E. \& Jensen D.A. 2003. Benthos as the basis for arctic lake food webs. Aquat. Ecol. 37: 437-445.

Siikavuopio S.I., Knudsen R. \& Amundsen P.-A. 2010. Growth and mortality of Arctic charr and European whitefish reared at low temperatures. Hydrobiologia 650: 255-263.

Skúlason S. \& Smith T.B. 1995. Resource polymorphism in vertebrates. Trends Ecol. Evol. 10: 366-370.

Solomon C.T., Carpenter S.R., Clayton M.K., Cole J.J., Coloso J.J., Pace M.L., Vander Zanden M.J. \& Weidel B.C. 2011. Terrestrial, benthic, and pelagic resource use in lakes: results from a three-isotope Bayesian mixing model. Ecology 92: 1115-1125.

Svenning M.-A., Klemetsen A. \& Olsen T. 2007. Habitat and food choice of Arctic charr in Linnévatn on Spitsbergen, Svalbard: the first year-round investigation in a High Arctic lake. Ecol. Freshw. Fish 16: 70-77.

Svärdson G. 1976. Interspecific population dominance in fish communities of Scandinavian lakes. Inst. Freshw. Res., Drottningholm 55: 144-171.

Syväranta J. \& Rautio M. 2010. Zooplankton, lipids and stable isotopes: importance of seasonal, spatial and taxonomical differences. Can. J. Fish. Aquat. Sci. 67: 1721-1729.

Syväranta J., Hämäläinen H. \& Jones R.I. 2006. Within-lake variability in carbon and nitrogen stable isotope signatures. Freshwat. Biol. 51: 1090-1102.

Thompson R.M., Brose U., Dunne J.A., Hall Jr R.O., Hladyz S., Kitching R.L., Martinez N.D., Rantala H., Romanuk T.N., Stouffer D.B. \& Tylianakis J.M. 2012. Food webs: reconciling the structure and function of biodiversity. Trends Ecol. Evol. 27: 689-697.

Ulvan E.M., Finstad A.G., Ugedal O. \& Berg O.K. 2012. Direct and indirect climate drivers of biotic interactions: ice-cover and carbon runoff shaping Arctic char Salvelinus alpinus and brown trout Salmo trutta competitive asymmetries. Oecologia 168: 277-287.

Vadeboncoeur Y., Vander Zanden M.J. \& Lodge D.M. 2002. Putting the lake back together: reintegrating benthic pathways into lake food web models. BioScience 52: 45-54. 
Vadeboncoeur Y., Peterson G., Vander Zanden M.J. \& Kalff J. 2008. Benthic algal production across lake size gradients: interactions among morphometry, nutrients, and light. Ecology 89: 2542-2552.

Vadeboncoeur Y., Jeppesen E., Vander Zanden M.J., Schierup H.-H., Christoffersen K. \& Lodge D.M. 2003. From Greenland to green lakes: cultural eutrophication and the loss of benthic pathways in lakes. Limnol. Oceanogr. 48: 1408-1418.

Vander Zanden M.J. \& Vadeboncoeur Y. 2002. Fishes as integrators of benthic and pelagic food webs in lakes. Ecology 83: 2152-2161.

Vander Zanden M.J., Casselman J.M. \& Rasmussen J.B. 1999a. Stable isotope evidence for the food web consequences of species invasions in lakes. Nature 401: 464-467.

Vander Zanden M.J., Vadeboncoeur Y. \& Chandra S. 2011. Fish reliance on littoral-benthic resources and the distribution of primary production in lakes. Ecosystems 14: 894-903.

Vander Zanden M.J., Shuter B.J., Lester N. \& Rasmussen J.B. 1999b. Patterns of food chain length in lakes: a stable isotope study. Am. Nat. 154: 406-416.

Vander Zanden M.J., Chandra S., Vadeboncoeur Y., Goldman C.R. 2006. Efficiencies of benthic and pelagic trophic pathways in a subalpine lake. Can. J. Fish. Aquat. Sci. 63: 2608-2620.

Vanni M.J. 2002. Nutrient cycling by animals in freshwater ecosystems. Annu. Rev. Ecol. Syst. 33: 341-370.

Vanni M.J., Duncan J.M., González M.J. \& Horgan M.J. 2009. Competition among aquatic organisms. In: Likens G.E. (ed.), Encyclopedia of Inland Waters, Elsevier, pp. 395-404.

Vincent W.F., Hobbie J.E. \& Laybourn-Parry J. 2008. Introduction to the limnology of high-latitude lake and river ecosystems. In: Vincent W.F. \& Laybourn-Parry J. (eds), Polar lakes and rivers: limnology of Arctic and Antarctic aquatic ecosystems, Oxford University Press, pp. 1-23.

Wagner A., Volkmann S., Dettinger-Klemm P.M.A. 2012. Benthic-pelagic coupling in lake ecosystems: the key role of chironomid pupae as prey for pelagic fish. Ecosphere 3: 1-17.

Werner E.E. \& Gilliam J.F. 1984. The ontogenetic niche and species interactions in size-structured populations. Ann. Rev. Ecol. Syst. 15: 393-425.

Wetzel R.G. 2001. Limnology: lake and river ecosystems. Elsevier, San Diego.

Woodward G., Ebenman B., Emmerson M., Montoya J.M., Olesen J.M. Valido A. \& Warren P.H. 2005. Body size in ecological networks. Trends Ecol. Evol. 20: 402-409. 


\title{
ORIGINAL PAPERS
}

\author{
I \\ SEASONAL AND ONTOGENETIC SHIFTS IN THE DIET OF \\ ARCTIC CHARR Salvelinus alpinus IN A SUBARCTIC LAKE
}

by

Antti P. Eloranta, Kimmo K. Kahilainen \& Roger I. Jones 2010

Journal of Fish Biology 77: 80-97.

Reprinted with kind permission of John Wiley and Sons () 


\title{
Seasonal and ontogenetic shifts in the diet of Arctic charr Salvelinus alpinus in a subarctic lake
}

\author{
A. P. Eloranta*†, K. K. Kahilainen†§ And R. I. Jones*
}

*University of Jyväskylä, Department of Biological and Environmental Sciences, PB 32, FI-40014 Jyväskylä, Finland, $\$$ University of Helsinki, Department of Environmental Sciences, PB 65, FI-00014 Helsinki, Finland and §Kilpisjärvi Biological Station, Käsivarrentie 14622, FI-99490 Kilpisjärvi, Finland

(Received 23 January 2009, Accepted 4 March 2010)

\begin{abstract}
Seasonal and ontogenetic shifts in the diet of Arctic charr Salvelinus alpinus were studied in a deep, ultra-oligotrophic lake in subarctic Finland from both stomach contents and the stable carbon $\left(\delta^{13} \mathrm{C}\right)$ and nitrogen $\left(\delta^{15} \mathrm{~N}\right)$ isotope compositions of muscle and liver tissues. Both diet and isotope results indicated that the S. alpinus population relied mainly on littoral benthic energy sources.

The strong littoral reliance appeared largely independent of season or fish size, although the data lacked small (total length, $L_{\mathrm{T}},<130 \mathrm{~mm}$ ) and young ( $<3$ years) $S$. alpinus. Liver isotope values of intermediate-sized S. alpinus $(200-350 \mathrm{~mm})$, however, suggested exploitation of the increase in the abundance of pelagic zooplankton in the late open-water season. The results suggest that, in general, a strong littoral reliance of fishes can be a feature in subarctic lakes throughout the year. Due to its faster isotopic turnover rate and thus higher resolution for temporal diet changes, liver could be more commonly used in stable-isotope studies of fish trophic niche shifts instead of using only the less responsive muscle tissue.$$
\text { (c) } 2010 \text { The Author }
$$

Journal compilation @ 2010 The Fisheries Society of the British Isle
\end{abstract}

Key words: benthic; food web; pelagic; stable-isotope analysis; trophic niche.

\section{INTRODUCTION}

Fishes often play a key role in lake ecosystems as integrators and controllers of littoral and pelagic food webs due to their high mobility, rapid behavioural responses and flexible feeding on both benthic (e.g. aquatic insect larvae and molluscs) and pelagic (e.g. crustacean zooplankton) prey (Polis et al., 1997; Vadeboncoeur et al., 2002; Vander Zanden \& Vadeboncoeur, 2002). Coupling between benthic and pelagic food webs is particularly evident in small, unproductive high latitude lakes, where animals have to cope with limited and seasonally fluctuating food resources (Schindler \& Scheuerell, 2002; Christoffersen et al., 2008). In these lakes, littoral benthic food webs (i.e. the energy flow from benthic algae to benthivorous fishes via littoral benthic macroinvertebrates) have frequently been shown to be of particular importance for the lake total production and ecosystem functioning (Welch \& Kalff, 1974;

$\dagger$ Author to whom correspondence should be addressed. Tel.: +358 142604237; fax: +358 142602321; email: antti.eloranta@jyu.fi 
Hecky \& Hesslein, 1995; Sierszen et al., 2003; Karlsson \& Byström, 2005). Pelagic phytoplankton production in high latitude lakes tends to be particularly constrained by the scarcity of dissolved nutrients, whereas clear water results in extensive illuminated littoral areas suitable for photosynthetic benthic algae (Liboriussen \& Jeppesen, 2003; Vadeboncoeur et al., 2003). The relative contribution of benthic and pelagic primary (Kalff \& Welch, 1974; Liboriussen \& Jeppesen, 2003; Forsström et al., 2005) and secondary (Hammar, 1989; Antonsson, 1992; Rautio et al., 2000) production, however, may undergo significant seasonal changes induced by the great annual fluctuations of light and temperature. In northern Fennoscandian lakes, pelagic zooplankton typically become most abundant in the late open-water season (i.e. between August and November) (Primicerio \& Klemetsen, 1999; Rautio et al., 2000; Bøhn \& Amundsen, 2001), whereas benthic macroinvertebrates are more continuously available, but may still show seasonal fluctuations in both density and biomass (Kahilainen et al., 2003).

Previous stable-isotope studies have demonstrated that littoral benthic production generally dominates the energy supply to fish top consumers in high latitude lakes (Hobson \& Welch, 1995; Sierszen et al., 2003; Karlsson \& Byström, 2005). In subarctic and Arctic regions, Arctic charr Salvelinus alpinus (L.) is the most common fish consumer and, due to its generalist diet and habitat use (Amundsen, 1995), often has a key role as a top-down controller of abundance and composition of littoral and pelagic organisms (Klemetsen et al., 2003a). The strong reliance of S. alpinus populations on littoral energy sources is suggested to result from the relatively higher primary production and larger size of prey organisms in the littoral benthic than in the pelagic habitat (Hobson \& Welch, 1995; Karlsson \& Byström, 2005). Seasonal changes in the food availability, however, can lead S. alpinus to shift to a more pelagic trophic niche (i.e. food and habitat) (Hindar \& Jonsson, 1982; Klemetsen et al., 2003b; Svenning et al., 2007; Amundsen et al., 2008; Amundsen \& Knudsen, 2009).

The trophic niche of S. alpinus may also depend on the population size structure and ontogenetic stage of individual fish. Because the risk of predation and the foraging efficiency depends on fish size, S. alpinus, like many other carnivorous fish species, typically undergo ontogenetic dietary shifts from small pelagic zooplankton to larger benthic macroinvertebrates (or sometimes vice versa) and finally to piscivory (Werner \& Gilliam, 1984; Hjelm et al., 2000; Amundsen et al., 2003; Klemetsen et al., 2003a). Small S. alpinus commonly prefer zooplankton as prey, but face a trade-off between foraging return and risk of death (Damsgård \& Ugedal, 1997; Jansen et al., 2003; Byström et al., 2004; Byström \& Andersson, 2005). The benthic habitat offers a better refuge from predators but a lower abundance of profitable zooplankton prey for small S. alpinus than the pelagic zone (Forseth et al., 1994; Klemetsen et al., 2003a; Byström et al., 2004). Consequently, S. alpinus may undergo an ontogenetic niche shift from benthic to pelagic once they have reached the size refuge from predation (L'Abée-Lund et al., 1993; Jonsson \& Jonsson, 2001; Byström et al., 2004), although foraging on relatively large benthic macroinvertebrates is generally more energy-efficient than feeding on small pelagic zooplankton (Forseth et al., 1994). Within lakes in which S. alpinus is the only fish species present, the largest S. alpinus may shift to cannibalism (Amundsen, 1994; Klemetsen et al., 2003a; Byström, 2006), but the extent of cannibalism can vary between individuals (Amundsen, 1994; Svenning \& Borgstrøm, 2005). Nevertheless, 
by controlling the growth, habitat use and abundance of smaller conspecifics, cannibalistic giants have a crucial role in trophic dynamics and ecosystem functioning (Svenning \& Borgstrøm, 1995; Claessen et al., 2000; Byström, 2006). Therefore, the overall energy flow from benthic and pelagic food webs to fish top consumers can be expected to depend strongly on the seasonal availability of these energy sources and also on the consumer population size structure.

Instead of short-term diet and habitat analyses, the possible temporal trophic niche shifts of S. alpinus can be studied by collecting fish in different times of the growth season (i.e. in spring, summer and autumn) and analysing the stable carbon and nitrogen isotope ratios $\left(\delta^{13} \mathrm{C}\right.$ and $\delta^{15} \mathrm{~N}$, respectively) of fish tissues with different isotopic turnover rates. While stomach contents reveal the most recently ingested prey items with high taxonomic resolution, the isotopic composition of fish tissues reflects the trophic position $\left(\delta^{15} \mathrm{~N}\right)$ and the relative contributions of assimilated littoral and pelagic energy sources $\left(\delta^{13} \mathrm{C}\right)$ over periods from a few weeks (liver) to several months (muscle) (Tieszen et al., 1983; Perga \& Gerdeaux, 2005). Thus, by analysing stable-isotope compositions of tissues with different isotopic turnover rates, it is not necessary to sample fishes as frequently as in traditional diet and habitat analyses to observe significant seasonal shifts in the energy source for fish top consumers.

In this study, muscle and liver tissues were used in stable-isotope analysis in tandem with stomach content analysis to evaluate, with appropriate temporal and taxonomic resolutions, the possible seasonal and ontogenetic trophic niche shifts of S. alpinus in the subarctic Lake Saanajärvi. The hypotheses were that S. alpinus generally rely more on littoral than on pelagic energy sources, but that the diet changes both during the growing season as pelagic crustacean zooplankton become more profitable in relation to littoral benthic prey, and during S. alpinus ontogeny as the tradeoff between profitability of different prey items and the risk of predation changes.

\section{MATERIALS AND METHODS}

\section{STUDY LAKE}

Saanajärvi is a subarctic lake situated in the extreme north-west part of Finnish Lapland $\left(69^{\circ} 03 \mathrm{~N} ; 20^{\circ} 52 \mathrm{E}\right)$ above the tree-line at $679 \mathrm{~m}$ a.s.l. in a valley between two $c .1000 \mathrm{~m}$ high hills. The area is subjected to little anthropogenic disturbance, but experiences great annual fluctuations of temperature, solar radiation and precipitation (Järvinen, 1987). The lake catchment area (460 ha) comprises subalpine vegetation and bare rock surfaces. Saanajärvi itself is a small (62 ha), ultraoligotrophic (annual means: total $\mathrm{P}=2.7 \mu \mathrm{gl}^{-1}$, total $\mathrm{N}=$ $\left.125.0 \mu \mathrm{g}^{-1}\right)$ and relatively deep $\left(Z_{\text {mean }}=5.1 \mathrm{~m}, Z_{\max }=24.0 \mathrm{~m}\right)$ lake (Rautio et al., 2000; Battarbee et al., 2002). The lake is dimictic and is usually ice-free between late June and midOctober (Rautio et al., 2000). The lake margins are mostly steep and rocky, and macrophytes are virtually absent. Saanajärvi consists almost equally of illuminated, rocky littoral zone $(53 \%)$ and of deep, pelagic open-water areas $(47 \%)$.

Saanajärvi was previously almost fishless, containing only a few brown trout Salmo trutta L. (K. Ranta, pers. comm.). In September 1993, 1050 S. alpinus of mean total length $\left(L_{\mathrm{T}}\right) 170 \mathrm{~mm}$ and mean total wet mass $\left(M_{\mathrm{W}}\right) 70.0 \mathrm{~g}$ were introduced from Pahtajärvi $\left(68^{\circ}\right.$ $25^{\prime} \mathrm{N} ; 23^{\circ} 35^{\prime}$ E) situated $130 \mathrm{~km}$ south-east from Saanajärvi. Another stocking was made in April 1997, when 600 S. alpinus of $L_{\mathrm{T}} 50-150 \mathrm{~mm}$ were transferred from small Čuovgijávri $\left(69^{\circ} 13^{\prime} \mathrm{N} ; 21^{\circ} 30^{\prime} \mathrm{E}\right)$ situated $35 \mathrm{~km}$ north-east from Saanajärvi. Nowadays, the fish community consists predominantly of small S. alpinus, with a few larger S. alpinus and a few S. trutta. There is no evidence that other fish species have ever been caught from the lake. 


\section{DATA COLLECTION}

\section{Fish}

Salvelinus alpinus were sampled during 2006 in spring (i.e. under ice in early April), summer (i.e. early July) and autumn (i.e. late September just before the lake froze over) using a gillnet series (five to 12 nets) comprising $30 \mathrm{~m}$ long and $1.8 \mathrm{~m}$ high gillnets having meshsizes $12-60 \mathrm{~mm}$ (knot to knot). Gillnet series $(n=1-2$ in each fishing occasion) were set in a line from shallow littoral to deep profundal. After $L_{\mathrm{T}}(\mathrm{mm})$ and $M_{\mathrm{W}}(\mathrm{g})$ were measured, otoliths (sagittae) and stomach were removed for later analyses. For stable-isotope analysis (SIA), part of the fish dorsal muscle and liver was dissected, dried on aluminium dishes at $60^{\circ} \mathrm{C}$ for 2 days, manually ground to a fine powder using a mortar and pestle and stored frozen in $2 \mathrm{ml}$ glass vials.

The age was assessed from untreated otoliths that were placed in a Petri dish filled with tap water for a couple of minutes and examined with a preparation microscope at a magnification of $\times 8-10$. For the sake of simplicity, all ages are given as full years rather than divided into full (April) and + (July and September) years. To examine the performance of S. alpinus age groups, Fulton's condition factor (Ricker, 1975) was calculated as: $K=10^{5} M_{\mathrm{W}} L_{\mathrm{T}}^{-3}\left(M_{\mathrm{W}}\right.$ in $\mathrm{g}$ and $L_{\mathrm{T}}$ in $\mathrm{mm}$, and $K$ is the condition factor multiplied with a scaling factor of $10^{5}$ to bring $K$ close to 1 ). A value of $K<1$ indicates a poor condition and $K>1$ indicates a good condition of fish. The growth of S. alpinus was measured by calculating the mean \pm S.D. $L_{\mathrm{T}}$ at given age, and using the von Bertalanffy three-parameter non-linear growth model (von Bertalanffy, 1938), which calculates the predicted $L_{\mathrm{T}}$ of $S$. alpinus at age $t$ as: $L_{\mathrm{T}}=L_{\infty}\left[1-e^{-k\left(t-t_{0}\right)}\right]$, where $L_{\infty}$ is the asymptotic $L_{\mathrm{T}}, k$ is the rate at which the growth curve approaches the asymptote and $t_{0}$ is the hypothetical time at which $L_{\mathrm{T}}$ was zero.

The stomach was removed from each fish and the prey items were identified to order, family or species level using a preparation microscope at a magnification of $\times 8-10$. The prey items were subsequently grouped into: (1) pelagic zooplankton, (2) littoral benthic prey, (3) chironomid larvae, (4) chironomid pupae, (5) surface insects and (6) fishes. Chironomid larvae and pupae were not included with littoral benthic prey because they may be of either littoral or profundal origin, and thus represent different energy sources for the fish. Because sufficient samples of particular prey items (e.g. Lymnaea sp. snails and chironomid pupae) were hard to obtain by general sampling methods, undigested specimens were also selected from fish stomach contents for SIA ( $c f$. Grey et al., 2002). The relative volume of each prey item in the fish stomach contents was estimated by the points method (Hynes, 1950). Stomach fullness was first visually estimated using a relative scale from 0 to 10 (0, empty stomach and 10, extended full stomach), and the contribution of each prey item was then given as a part of this stomach fullness value.

Salvelinus alpinus were subsequently divided into three $L_{\mathrm{T}}$ groups $(130-200,200-350$ and $>500 \mathrm{~mm}$ ), where selection was based on available stomach contents data: individuals $>500 \mathrm{~mm}$ were found to be cannibals and to feed on 150-190 mm fishes; S. alpinus 200-350 mm seemed to be shifting from an invertebrate diet to piscivory and had apparently reached a size refuge from predation by the larger cannibals; in contrast, S. alpinus 130-200 mm were evidently susceptible to predation. The diet overlap between $L_{\mathrm{T}}$ groups was estimated using the Schoener's (1970) similarity index: $\alpha=1-0 \cdot 5\left(\sum_{i=1}^{n}\left|p_{x i}-p_{y i}\right|\right)$ where $p_{x i}$ is the mean proportion of prey group $i$ used by the length group $x, p_{y i}$ is the mean proportion of prey group $i$ used by the length group $y$ and $n$ is the number of prey groups. A value of zero indicates no similarity between $L_{\mathrm{T}}$ groups, whereas a value of 1 suggests complete similarity. A diet similarity value of $\geq 0.6$ was considered biologically significant (Wallace, 1981).

Pelagic zooplankton, benthic macroinvertebrates and biofilm

Qualitative samples of pelagic zooplankton, benthic macroinvertebrates and biofilm were sampled for SIA from several sites in July and September 2006. Pelagic zooplankton was collected by vertical hauls $(n=10-15)$ from 0 to $15 \mathrm{~m}$ depth using a plankton net of $200 \mu \mathrm{m}$ mesh. After sieving through a $200 \mu \mathrm{m}$ mesh in the laboratory, zooplankton was put into cool tap water overnight to allow for gut evacuation. When abundances permitted, zooplankton was manually sorted into cladocerans, calanoid copepods and predatory cladocerans. Littoral 
benthic macroinvertebrates were sampled using a kicknet of $500 \mu \mathrm{m}$ mesh in $0-1 \mathrm{~m}$ depth and an Ekman grab $($ area $=157 \times 157 \mathrm{~mm}$ ) in $2-6 \mathrm{~m}$ depth, whereas profundal benthic macroinvertebrates were collected with the Ekman grab from 17 to 24 m depth. Several Ekman replicates were needed to obtain sufficient samples from both littoral $(n=5-8)$ and profundal $(n=10-15)$ sampling sites. After sieving through a $500 \mu \mathrm{m}$ mesh, benthic macroinvertebrates were separated from detritus and put into cool tap water to allow animals to void their guts. The following day benthic macroinvertebrates were identified to order, family or species level and separated for later SIA. In the case of molluscs, only the soft body tissue was analysed. Biofilm samples scraped from small stones picked from the lake shore $(<1 \mathrm{~m}$ deep) were first filtered through a $200 \mu \mathrm{m}$ mesh to remove excess water and then manually cleaned of all visible non-algal particles. After initial preparation, all samples were dried at $60^{\circ} \mathrm{C}$ for 2 days, manually ground to a fine powder using a mortar and pestle (hard and large samples) or a spatula (soft and small samples) and stored frozen in $2 \mathrm{ml}$ glass vials until SIA.

\section{STABLE-ISOTOPE ANALYSIS}

Carbon and nitrogen SIA were conducted using a FlashEA 1112 elemental analyser coupled to a Thermo Finnigan DELTA ${ }^{\text {plus }}$ Advantage mass spectrometer (www.thermofisher.com). Pike Esox lucius L. white muscle tissue was used as an internal laboratory working standard for animal tissue samples, and potato Solanum tuberosum leaves were used as an internal working standard for biofilm samples; these internal laboratory working standards were calibrated against IAEA standards [i.e. IAEA-CH-6 and IAEA-CH-7 for carbon, and IAEA-N-1 and IAEA-N-2 for nitrogen (http://curem.iaea.org)]. Two replicates were run from each sample and in each run replicate standards were inserted after every five samples. Results are expressed as delta $(\delta)$ values in per thousand $(\%): \delta=1000\left[\left(R_{\text {sample }} R_{\text {standard }}^{-1}\right)-1\right]$, where $R={ }^{13} \mathrm{C}:{ }^{12} \mathrm{C}$ or ${ }^{15} \mathrm{~N}:{ }^{14} \mathrm{~N}$. In each run, S.D. of $\delta^{13} \mathrm{C}$ and $\delta^{15} \mathrm{~N}$ values was, respectively, $<0 \cdot 2$ and $0.6 \%$ for standards. The muscle and liver $\delta^{13} \mathrm{C}$ values were not corrected for lipids, because the lipid content of both tissues was evidently low according to their C:N ratios and because of the uncertainty of their applicability to liver of lipid-normalization procedures originally developed for muscle tissue (Kiljunen et al., 2006).

A two-source isotope mixing model was used to estimate the relative contribution of littoral carbon (i.e. energy) sources to $S$. alpinus body carbon $\left(Z_{\text {tissue }}\right)$. The model compares the observed $\delta^{13} \mathrm{C}$ and $\delta^{15} \mathrm{~N}$ values of fish to the isotopic compositions of littoral and pelagic baselines and gives estimates as percentage values $(\%)$ using the following equation (Karlsson \& Byström, 2005): $Z_{\text {tissue }}=100\left\{\left[\delta^{13} C_{\text {fish }}-\delta^{13} C_{\text {pel }}-\left(\delta^{15} N_{\text {fish }}-\delta^{15} N_{\text {pel }}\right) X\right]\left[(1-X Y)\left(\delta^{13} C_{\text {lit }}\right.\right.\right.$ $\left.\left.-\delta^{13} C_{\mathrm{pel}}\right)^{-1}\right]^{-1}$, where $X$ is the slope of the commonly used trophic isotopic fractionation of carbon and nitrogen $\left(\Delta_{\mathrm{C}} \Delta_{\mathrm{N}}^{-1}, 0.47 \div 3.46 \%\right.$ ) (Vander Zanden \& Rasmussen, 2001) and $Y$ is the slope of the linear relationship between the pelagic and littoral baselines (here 0.0214). In this study, the pelagic baseline values $\left(\delta^{13} \mathrm{C}_{\mathrm{pel}}\right.$ and $\left.\delta^{15} \mathrm{~N}_{\mathrm{pel}}\right)$ were calculated as the mean $\delta^{13} \mathrm{C}$ and $\delta^{15} \mathrm{~N}$ values of all cladoceran and calanoid copepod samples, whereas the littoral baseline values $\left(\delta^{13} \mathrm{C}_{\mathrm{lit}}\right.$ and $\left.\delta^{15} \mathrm{~N}_{\mathrm{lit}}\right)$ were calculated as the mean $\delta^{13} \mathrm{C}$ and $\delta^{15} \mathrm{~N}$ values of all those benthic macroinvertebrate taxa sampled from the lake littoral that had been observed in S. alpinus stomach contents (Table I). Fixed littoral and pelagic baseline values were used, because they did not differ significantly between July and September (Mann-Whitney $U$-test, $n=35, P>0.05)$ and because only fish samples were obtained in April. For the sake of simplicity, any $Z_{\text {tissue }}$ estimates $>100 \%$ were assigned as $100 \%$.

\section{STATISTICAL ANALYSES}

Pair-wise $t$-test was used to test differences in $\delta^{13} \mathrm{C}$ and $\delta^{15} \mathrm{~N}$ values between $S$. alpinus muscle and liver tissues. To study the ontogenetic niche shifts, linear regression was used to test the relationship between $S$. alpinus $L_{\mathrm{T}}$ and $Z_{\text {tissue }}$ estimates (i.e. energy source) or $\delta^{15} \mathrm{~N}_{\text {tissue }}$ values (i.e. trophic position). Because the ANOVA assumptions of normality and homoscedasticity were not met, non-parametric Kruskal-Wallis ANOVA was used to compare $\delta^{13} \mathrm{C}$ and $\delta^{15} \mathrm{~N}$ values among littoral, pelagic and profundal invertebrates, $Z_{\text {tissue }}$ estimates 
TABLE I. Stable carbon $\left(\delta^{13} \mathrm{C}\right)$ and nitrogen $\left(\delta^{15} \mathrm{~N}\right)$ isotope values of pelagic, littoral and profundal organisms from Saanajärvi, north-western Finnish Lapland $\left(69^{\circ} 05^{\prime} \mathrm{N} ; 20^{\circ} 55^{\prime} \mathrm{E}\right)$, collected in July and September 2006. Values are means \pm S.D. of $n$ samples

\begin{tabular}{|c|c|c|c|c|c|}
\hline \multirow[b]{2}{*}{ Organism } & \multirow[b]{2}{*}{$n$} & \multicolumn{2}{|c|}{$\delta^{13} \mathrm{C}$} & \multicolumn{2}{|c|}{$\delta^{15} \mathrm{~N}$} \\
\hline & & Mean \pm S.D. & Range & Mean \pm S.D. & Range \\
\hline All pelagic zooplankton & 13 & $-33 \cdot 3 \pm 4 \cdot 5$ & -34.8 to -29.8 & $4.5 \pm 1.6$ & $2 \cdot 1-6 \cdot 4$ \\
\hline Cladocera* & 6 & $-32.8 \pm 1.9$ & -34.3 to $-29 \cdot 8$ & $4.8 \pm 1.9$ & $2 \cdot 1-6 \cdot 4$ \\
\hline Calanoida* & 6 & $-33.9 \pm 0.6$ & -34.8 to $-33 \cdot 1$ & $4 \cdot 3 \pm 1 \cdot 5$ & $2 \cdot 5-6 \cdot 1$ \\
\hline Bythotrephes longimanus* & 1 & $-33 \cdot 4$ & & $4 \cdot 2$ & \\
\hline All littoral biofilm & 10 & $-21 \cdot 6 \pm 4 \cdot 3$ & $-27 \cdot 3$ to -14.9 & $1 \cdot 1 \pm 0 \cdot 6$ & $0 \cdot 2-2 \cdot 3$ \\
\hline $\begin{array}{l}\text { All littoral benthic } \\
\text { invertebrates }\end{array}$ & 67 & $-23 \cdot 3 \pm 3 \cdot 1$ & -29.7 to $-17 \cdot 1$ & $4.4 \pm 1.4$ & $1 \cdot 6-7 \cdot 5$ \\
\hline Chironomidae* & 18 & $-20 \cdot 5 \pm 2 \cdot 2$ & $-23 \cdot 6$ to $-17 \cdot 1$ & $5 \cdot 6 \pm 1 \cdot 2$ & $2 \cdot 8-7 \cdot 5$ \\
\hline Gammarus lacustris* & 10 & $-21 \cdot 8 \pm 1 \cdot 6$ & $-23 \cdot 8$ to $-18 \cdot 2$ & $4 \cdot 1 \pm 0.6$ & $3 \cdot 3-5 \cdot 2$ \\
\hline Apatanidae (Trichoptera)* & 6 & $-26 \cdot 7 \pm 1 \cdot 6$ & -29.7 to $-25 \cdot 0$ & $4.9 \pm 1 \cdot 1$ & $3 \cdot 5-6 \cdot 0$ \\
\hline Perlodidae (Plecoptera)* & 3 & $-24 \cdot 3 \pm 2 \cdot 5$ & $-26 \cdot 2$ to -21.4 & $4 \cdot 0 \pm 0.8$ & $3 \cdot 2-4 \cdot 8$ \\
\hline Lymnaea* $^{*}$ & 6 & $-24 \cdot 1 \pm 2 \cdot 5$ & $-28 \cdot 1$ to $-21 \cdot 8$ & $3 \cdot 0 \pm 0 \cdot 8$ & $1 \cdot 6-3 \cdot 8$ \\
\hline Pisidium sp.* & 5 & $-27 \cdot 4 \pm 1 \cdot 5$ & $-28 \cdot 5$ to $-25 \cdot 4$ & $4 \cdot 1 \pm 0 \cdot 1$ & $3 \cdot 9-4 \cdot 3$ \\
\hline Dytiscidae* & 3 & $-25 \cdot 2 \pm 3 \cdot 6$ & -28.5 to -21.4 & $4.4 \pm 0.5$ & $3 \cdot 8-4 \cdot 8$ \\
\hline Siphlonuridae & 5 & $-27.9 \pm 1.4$ & $-29 \cdot 1$ to $-25 \cdot 8$ & $3 \cdot 5 \pm 0.6$ & $2 \cdot 8-4 \cdot 2$ \\
\hline Tubificidae (Oligochaeta) & 5 & $-23.4 \pm 1.6$ & -25.8 to -21.8 & $3 \cdot 5 \pm 0 \cdot 3$ & $3 \cdot 1-3 \cdot 9$ \\
\hline Tipulidae (larvae) & 4 & $-22 \cdot 4 \pm 0.5$ & -22.8 to -21.6 & $2 \cdot 3 \pm 0 \cdot 0$ & $2 \cdot 3-2 \cdot 3$ \\
\hline Hydrachnidae & 2 & $-22 \cdot 5$ & $-24 \cdot 1$ to $-20 \cdot 1$ & $3 \cdot 9$ & $3 \cdot 8-3 \cdot 9$ \\
\hline $\begin{array}{l}\text { All profundal benthic } \\
\text { invertebrates }\end{array}$ & 15 & $-29 \cdot 5 \pm 2 \cdot 2$ & -31.9 to -25.3 & $7 \cdot 5 \pm 1 \cdot 3$ & $6 \cdot 0-10 \cdot 3$ \\
\hline Chironomidae* & 12 & $-30 \cdot 5 \pm 1 \cdot 1$ & -31.9 to $-28 \cdot 5$ & $7 \cdot 0 \pm 0 \cdot 8$ & $6 \cdot 0-8 \cdot 6$ \\
\hline Tubificidae (Oligochaeta) & 3 & $-25 \cdot 8 \pm 0.8$ & $-26 \cdot 6$ to $-25 \cdot 3$ & $9 \cdot 4 \pm 1 \cdot 3$ & $7 \cdot 9-10 \cdot 0$ \\
\hline
\end{tabular}

Range, the minimum and maximum observed values; *, organisms that were also found in Salvelinus alpinus stomach contents.

and $\delta^{15} \mathrm{~N}_{\text {tissue }}$ values among $S$. alpinus $L_{\mathrm{T}}$ groups, as well as $Z_{\text {tissue }}$ estimates of $S$. alpinus 130-200 and 200-350 mm between seasons. When statistically significant differences were found $(P<0.05)$, non-parametric Mann-Whitney $U$-tests were further used in pair-wise comparisons. All statistical tests were done using SPSS 14.0 software (www.spss.com).

\section{RESULTS}

A total of 122 S. alpinus were studied, of which 70 were $130-200 \mathrm{~mm}, 47$ were $200-350 \mathrm{~mm}$ and five were $>500 \mathrm{~mm} L_{\mathrm{T}}$. In July and September, S. alpinus $130-200 \mathrm{~mm}$ were caught in large numbers, but only random sub-samples of 39 and 24 individuals were analysed, respectively. The S. alpinus $L_{\mathrm{T}}$ varied between 136 and $555 \mathrm{~mm}$ (mean \pm S.D. $=209 \pm 77 \mathrm{~mm}$ ), while $M_{\mathrm{W}}$ ranged from 18 to $2155 \mathrm{~g}$ (mean \pm S.D. $=130 \pm 316 \mathrm{~g}$ ). No S. alpinus $<136 \mathrm{~mm}$ or $347-504 \mathrm{~mm} L_{\mathrm{T}}$ were caught. The age of $S$. alpinus ranged from 3 to 15 years, but most individuals were 5-7 years old. Most $S$. alpinus had grown slowly and were in rather poor condition (Fig. 1). Large variation in $L_{\mathrm{T}}$ at a given age, however, indicated marked individual 

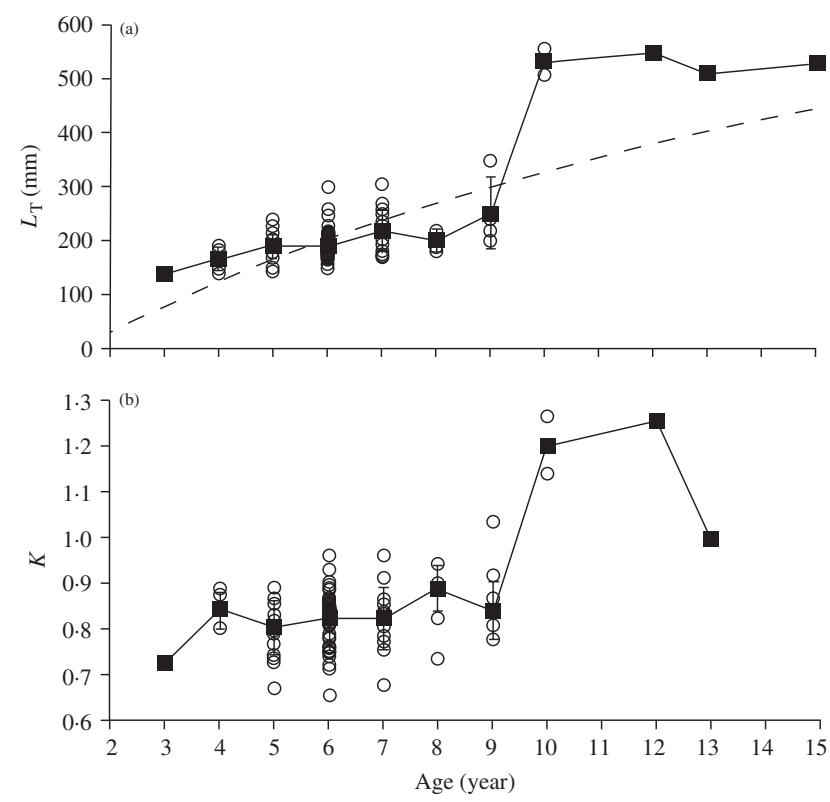

Fig. 1. Salvelinus alpinus $(n=101)$ (a) total length $\left(L_{\mathrm{T}}\right)$ and (b) condition factor $(K)$ as a function of age in Saanajärvi, north-west Finland. The von Bertalanffy non-linear growth curve $\left(L_{\infty}=720, k=0.07\right.$, $\left.t_{0}=1.4\right)$ is shown $\left({ }_{--}\right)$. The oldest individual of age 15 years was excluded from (b), because of its exceptionally low condition factor $(K=0.45)$. Values are means \pm S.D. ( $\square)$ and individual values $(\mathrm{O})$.

differences in growth rates (e.g. the $L_{\mathrm{T}}$ at age 6 years ranged from 150 to $296 \mathrm{~mm}$ ). $K$ differed significantly between $S$. alpinus $L_{\mathrm{T}}$ groups (Kruskal-Wallis ANOVA, $n=121, P<0.05$ ). Salvelinus alpinus $>500 \mathrm{~mm}$ had not only grown faster, but also were in significantly better condition than most 130-200 mm (Mann-Whitney $U$-test, $n=75, P<0.05$ ) and 200-350 mm fish (Mann-Whitney $U$-test, $n=51$, $P<0.05)$, with the exception of the oldest $S$. alpinus $\left(L_{\mathrm{T}}=528 \mathrm{~mm}, M_{\mathrm{W}}=668 \mathrm{~g}\right)$ individual, which was in an exceptionally poor condition due to a blockage (i.e. a fishing line and lure) in its intestine.

\section{STOMACH CONTENTS}

In all, 122 S. alpinus stomachs were examined, of which 107 contained prey. A total of 17 different prey items were identified including: (1) pelagic zooplankton (cladocerans Daphnia hyalina, calanoid copepods Eudiaptomus graciloides and predatory cladocerans Bythotrephes longimanus); (2) littoral benthic prey (amphipods Gammarus lacustris, trichopteran larvae Apatanidae, plecopteran nymphs Perlodidae, water beetles Dytiscidae, snails Lymnaea and mussels Pisidium sp.); (3) chironomid larvae (Chironomini, Tanypodinae and Prodiamesinae); (4) chironomid pupae; (5) surface insects (Tipulidae, Diptera, Hymenoptera and Coleoptera); (6) fish 
(S. alpinus). The diet of S. alpinus $130-200$ and 200-350 $\mathrm{mm}$ showed significant overlap $(\alpha=0.73)$ and consisted mostly of chironomid larvae and pupae, and to a lesser extent of other benthic prey dominated by G. lacustris and Apatanidae (Fig. 2). In general, pelagic zooplankton (mostly D. hyalina) and surface insects (mostly Tipulidae and Diptera) comprised only a small portion of the S. alpinus diet. Salvelinus alpinus $>500 \mathrm{~mm}$ had clearly different diets compared with both $130-200 \mathrm{~mm}(\alpha=0.29)$ and $200-350 \mathrm{~mm}(\alpha=0.23)$ fish. These large $S$. alpinus had shifted to cannibalism and eaten smaller conspecifics of 150-190 $\mathrm{mm} L_{\mathrm{T}}(n=4)$ except the one individual caught in July, which had recently eaten a large number of G. lacustris and also adult Tipulidae. The largest S. alpinus 200-350 mm $\left(L_{\mathrm{T}}=347 \mathrm{~mm}, M_{\mathrm{W}}=383 \mathrm{~g}\right)$ had also eaten a smaller individual $\left(L_{\mathrm{T}}=150 \mathrm{~mm}\right)$ indicating an ontogenetic diet shift to cannibalism.

Although benthic prey clearly dominated the diet of S. alpinus 130-200 and 200-350 mm, some dietary shifts were observed depending on the seasonal availability of different prey items (Fig. 2). In April, small S. alpinus had fed nearly exclusively on chironomid larvae and G. lacustris, whereas in July the diet was dominated by chironomid pupae, but also included other kinds of prey, such as surface insects, littoral benthic prey and pelagic zooplankton. Although benthic prey (mostly Apatanidae and chironomid larvae) dominated the diet, the relative contribution of pelagic zooplankton in the stomach contents of S. alpinus 130-200 and 200-350 mm showed a slight increase from April towards September, suggesting a partial seasonal shift from benthic to a more pelagic trophic niche.

\section{STABLE ISOTOPES}

Regardless of season, littoral, pelagic and profundal organisms differed markedly in their isotopic compositions (Kruskal-Wallis ANOVA, $n=55, P<0.001$ ). Pelagic zooplankton had significantly lower $\delta^{13} \mathrm{C}$ values (Mann-Whitney $U$-test, $n=49, P<0.001$ ), but similar $\delta^{15} \mathrm{~N}$ values (Mann-Whitney $U$-test, $n=49, P>$ 0.05 ) than littoral benthic macroinvertebrates (Table I and Fig. 3), which indicates that these primary consumers generally use distinct energy sources of different carbon isotopic composition. In contrast, profundal benthic macroinvertebrates had slightly higher $\delta^{13} \mathrm{C}$ values than pelagic zooplankton, but significantly higher $\delta^{15} \mathrm{~N}$ values than both pelagic zooplankton (Mann-Whitney $U$-test, $n=20, P<0.001$ ) and littoral benthic macroinvertebrates (Mann-Whitney $U$-test, $n=41, P<0.001$ ). This suggests that profundal macroinvertebrates mostly consume settling seston, including pelagic zooplankton, and thus occupy a slightly higher trophic position than most pelagic and littoral primary consumers.

Stable carbon and nitrogen isotopes of muscle and liver tissue were analysed from a total of 79 S. alpinus. In July and September, random sub-samples of 18 and 17 individuals, respectively, of S. alpinus $130-200 \mathrm{~mm}$ were chosen for SIA. In general, the $\delta^{13} \mathrm{C}$ values of muscle (mean \pm s.D. $=-22.9 \pm 1.9 \%$, range $=$ -26.3 to $-18.6 \%$ ) were significantly higher (paired sample $t$-test, $n=79, P<$ 0.001 ) and showed less individual variation than the liver $\delta^{13} \mathrm{C}$ values (mean \pm S.D. $=-24.3 \pm 2.5 \%$, range $=-29.5$ to $-19.4 \%$ ) (Fig. 3). The $\delta^{15} \mathrm{~N}$ values of muscle (mean \pm S.D. $=9 \cdot 2 \pm 0.8 \%$ o, range $=7 \cdot 6-11.8 \%$ ) were also significantly higher (paired sample $t$-test, $n=79, P<0.001$ ) than those of liver (mean \pm S.D. $=8 \cdot 3 \pm 0.9 \%$, range $=6 \cdot 8-11 \cdot 1 \%$ o) 

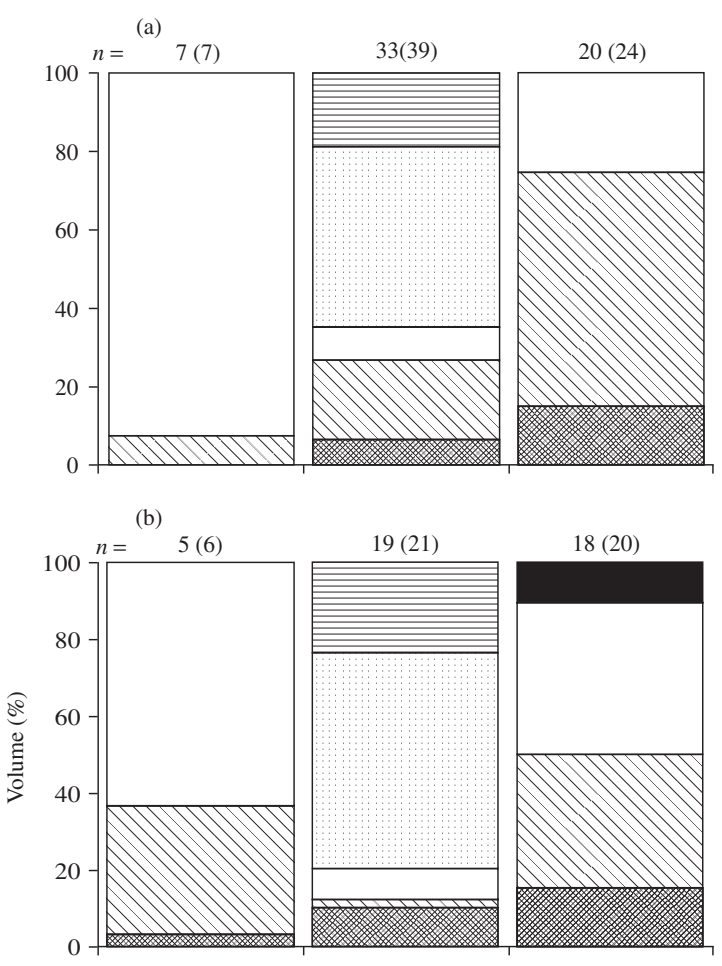

(c)

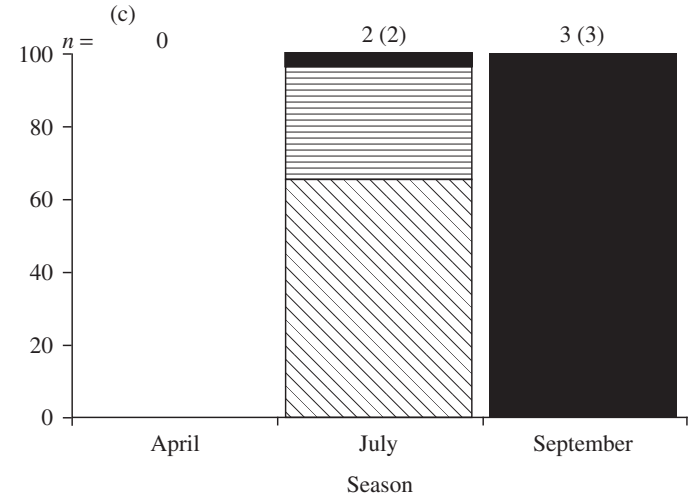

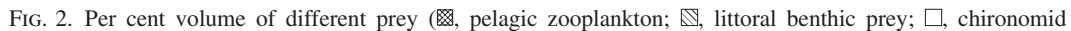
larvae; $\square$, chironomid pupae; 目, surface insects; $\square$, fishes) in the stomach contents of Salvelinus alpinus in total length classes (a) 130-200, (b) 200-350 and (c) >500 mm caught from Saanajärvi, north-west Finland, in different seasons. The number of stomachs containing prey remains $(n)$ is shown above the bars with the total number of stomachs examined in parentheses. [Correction added after online publication 2 July 2010, figure key corrected so that appropriate symbols were matched to figure]. 


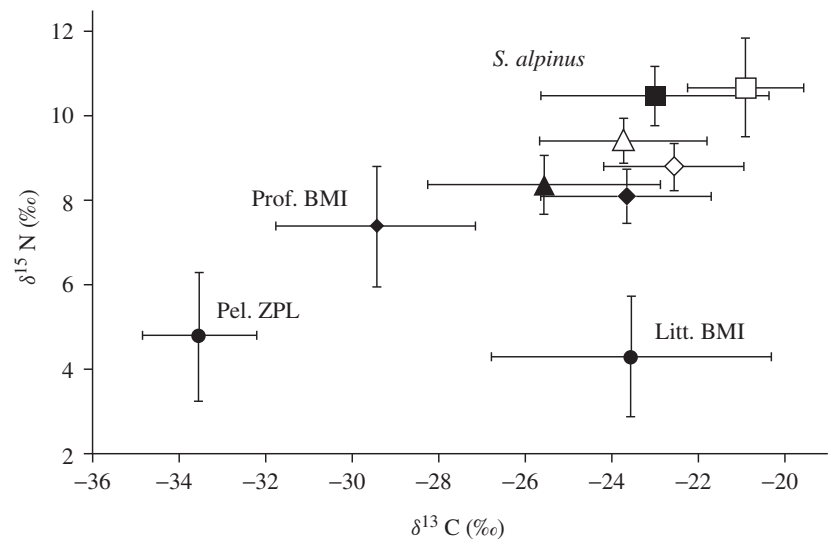

FIG. 3. Stable-isotope biplot for Saanajärvi, north-west Finland, showing stable carbon $\left(\delta^{13} \mathrm{C}\right)$ and nitrogen $\left(\delta^{15} \mathrm{~N}\right)$ isotopic composition (values are means \pm s.D.) of pelagic zooplankton (Pel. ZPL), of littoral and profundal benthic macroinvertebrates (Litt. BMI and Prof. BMI, respectively) and of muscle $(\diamond, \triangle$ $\square)$ and liver $(\boldsymbol{\nabla}, \boldsymbol{\Delta}, \boldsymbol{\square})$ tissues from Salvelinus alpinus 130-200 $(\diamond, \diamond ; n=42), 200-350(\Delta, \mathbf{\Delta}$; $n=32)$ and $>500(\square, \mathbf{\square} ; n=5) \mathrm{mm}$ total length.

The clear separation between littoral $\left(\delta^{13} \mathrm{C}_{\text {lit }}=-21.8 \% o, \delta^{15} \mathrm{~N}_{\text {lit }}=4.5 \%, n=43\right)$ and pelagic $\left(\delta^{13} \mathrm{C}_{\mathrm{pel}}=-32.9 \%\right.$ o, $\left.\delta^{15} \mathrm{~N}_{\mathrm{pel}}=3.9 \%, n=12\right)$ isotopic baselines enabled the use of a two-source mixing model to estimate the relative reliance of $S$. alpinus on different energy sources. The $Z_{\text {muscle }}$ (mean \pm s.D. $=83 \pm 15 \%$, range $=53-100 \%$ ) and $Z_{\text {liver }}$ (mean \pm S.D. $=71 \pm 22 \%$, range $=26-100 \%$ ) estimates indicated that the $S$. alpinus population generally relied more on littoral than on pelagic energy sources, but that individuals within the population differed substantially in their source of energy. There were no significant relationships between the $Z_{\text {tissue }}$ estimates and $L_{\mathrm{T}}$ (linear regression, $n=79, P>0.05$; Fig. 4), suggesting that the reliance on littoral energy sources was largely independent of $S$. alpinus size. Both $Z_{\text {muscle }}$ (Kruskal-Wallis ANOVA, $n=79, P=0.001$ ) and $Z_{\text {liver }}$ (Kruskal-Wallis ANOVA, $n=79, P<0.05$ ) estimates differed significantly between $S$. alpinus $L_{\mathrm{T}}$ groups. Salvelinus alpinus $200-350 \mathrm{~mm}$ had significantly lower $Z_{\text {muscle }}$ estimates compared with 130-200 mm (Mann-Whitney $U$-test, $n=74, P<0.05$ ) and $>500 \mathrm{~mm}$ fish (Mann-Whitney $U$-test, $n=74, P<0.05$ ), but also lower $Z_{\text {liver }}$ estimates compared with 130-200 mm fish (Mann-Whitney $U$-test, $n=74, P=0.001$ ), indicating a slightly more pelagic trophic niche of S. alpinus $200-350 \mathrm{~mm}$.

In contrast to $Z$ estimates, the $\delta^{15} \mathrm{~N}_{\text {muscle }}$ and $\delta^{15} \mathrm{~N}_{\text {liver }}$ values of $S$. alpinus showed a significant positive relationship with $L_{\mathrm{T}}$ (linear regression, $n=79, P<0.001$; Fig. 5), although individual variation within all $L_{\mathrm{T}}$ groups was high. The $S$. alpinus $L_{\mathrm{T}}$ groups differed significantly by their $\delta^{15} \mathrm{~N}_{\text {muscle }}$ (Kruskal-Wallis ANOVA, $n=$ $79, P<0.001$ ) and $\delta^{15} \mathrm{~N}_{\text {liver }}$ (Kruskal-Wallis ANOVA, $n=79, P<0.001$ ) values. The large S. alpinus $>500 \mathrm{~mm}$ had significantly higher $\delta^{15} \mathrm{~N}_{\text {muscle }}$ (Mann-Whitney $U$-test, $\quad n=47, \quad P<0.001$ ) and $\delta^{15} \mathrm{~N}_{\text {liver }}$ (Mann-Whitney $U$-test, $n=47$, $P<0.001)$ values compared with $S$. alpinus $130-200 \mathrm{~mm}$ fish, and also compared 


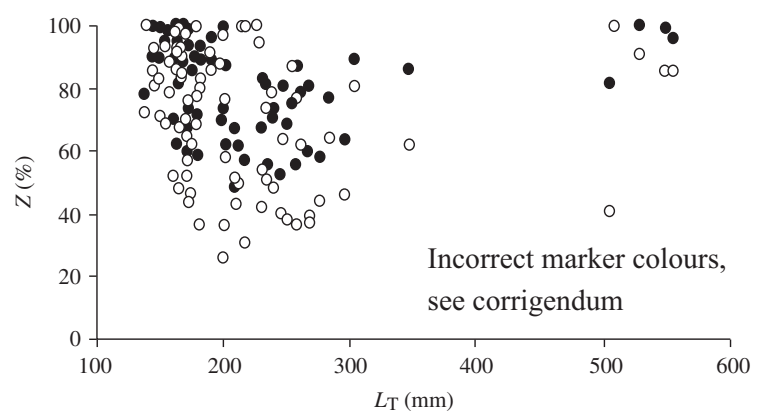

FIG. 4. Estimated dependence of Salvelinus alpinus $(n=79)$ in Saanajärvi, north-west Finland, on littoral energy sources $(Z)$ as a function of total length $\left(L_{\mathrm{T}}\right) . Z$ estimates based on stable-isotope analysis of S. alpinus muscle $(O)$ and liver $(\bullet)$ tissues are shown.

with $\delta^{15} \mathrm{~N}_{\text {muscle }}$ (Mann-Whitney $U$-test, $n=37, P<0.05$ ) and $\delta^{15} \mathrm{~N}_{\text {liver }}$ (MannWhitney $U$-test, $n=37, P<0 \cdot 001)$ values of $200-350 \mathrm{~mm}$ fish. The $\delta^{15} \mathrm{~N}_{\text {muscle }}$, but not $\delta^{15} \mathrm{~N}_{\text {liver }}$, value of $S$. alpinus $200-350 \mathrm{~mm}$ were also significantly higher compared with 130-200 mm fish (Mann-Whitney $U$-test, $n=74, P<0.001$ ).

According to both $Z_{\text {muscle }}$ and $Z_{\text {liver }}$ estimates, S. alpinus $130-200 \mathrm{~mm}$ did not undergo a significant seasonal shift in their energy source (Kruskal-Wallis ANOVA, $n=42, P>0.05$; Fig. 6). In contrast, the $Z_{\text {muscle }}$ and particularly the $Z_{\text {liver }}$ estimates of $S$. alpinus 200-350 mm suggested a slight, although not statistically significant, seasonal shift from littoral to a more pelagic energy source (Kruskal-Wallis ANOVA, $n=32, P>0.05)$. In September, S. alpinus $200-350 \mathrm{~mm}$ had lower $Z_{\text {liver }}$ estimates (mean \pm S.D. $=53 \pm 5 \%, n=15)$ than in April (mean \pm s.D. $=70 \pm 21 \%$, $n=6$ ) or July (mean \pm S.D. $=66 \pm 18 \%, n=11$ ). If the two individuals with exceptionally high $Z$ estimates had been removed from the data (Fig. 6), the $Z_{\text {liver }}$ estimates would have shown significant seasonal differences (Kruskal-Wallis ANOVA,

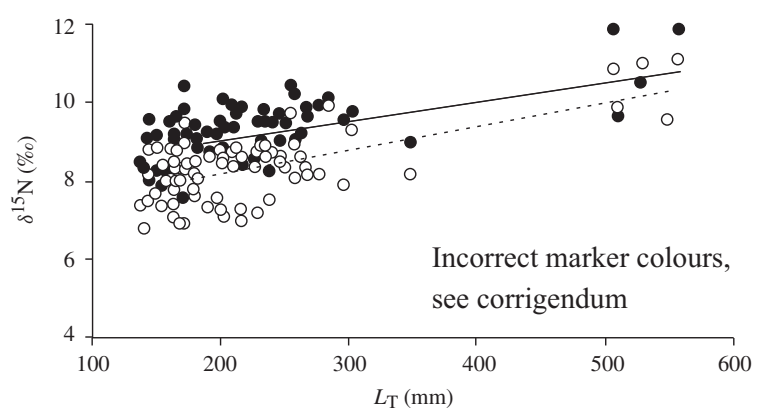

FIG. 5. $\delta^{15} \mathrm{~N}$ values of muscle $(\mathrm{O})$ and liver $(\bullet)$ tissues of Salvelinus alpinus in Saanajärvi, north-west Finland, as a function of total length $\left(L_{\mathrm{T}}\right)$. The curves were fitted by: muscle $y=0.005 x+8.018\left(r^{2}=0.388\right.$, $n=79, P<0.001)$ and liver $y=0.006 x+6.975\left(r^{2}=0.435, n=79, P<0.001\right)$. 


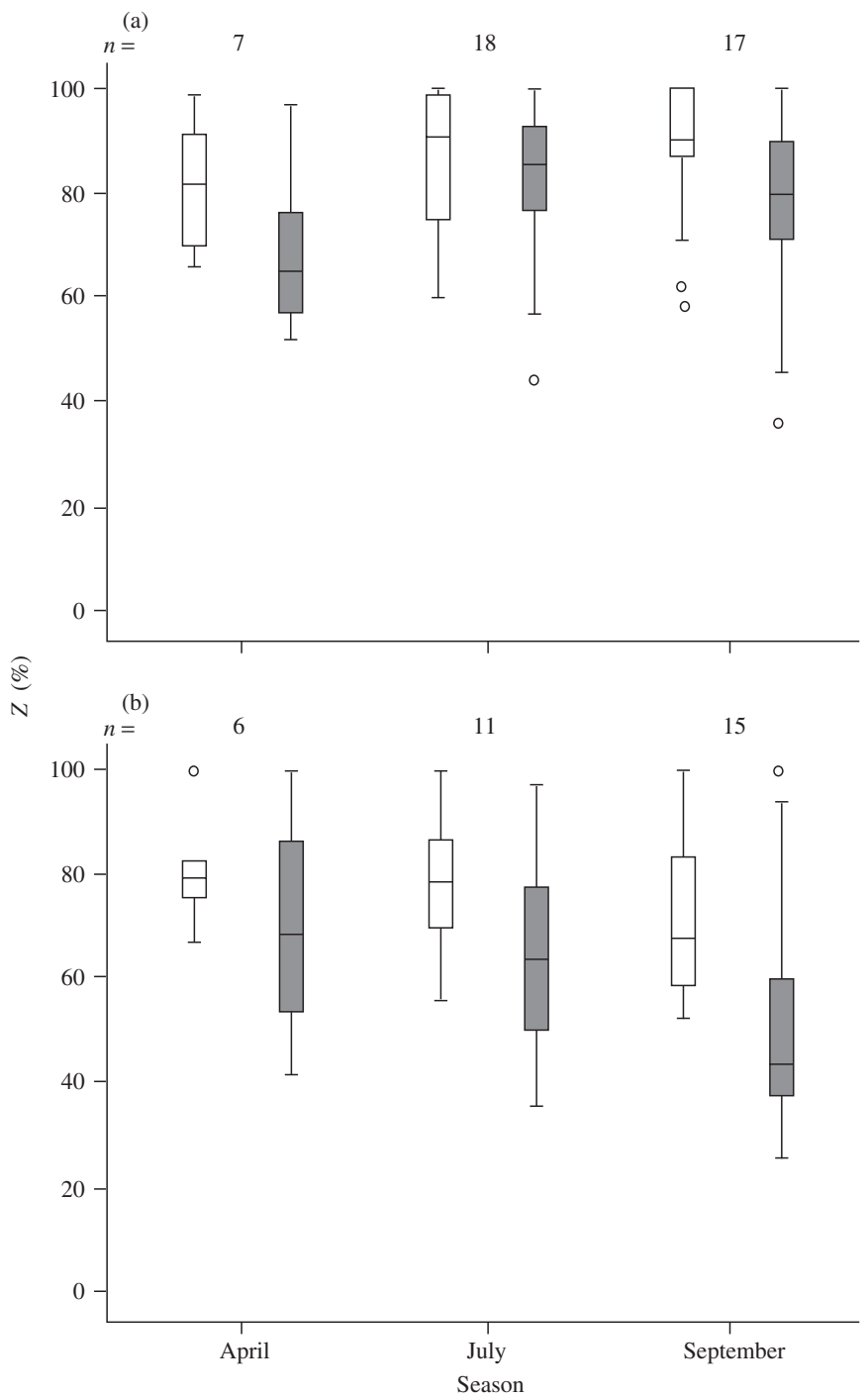

Fig. 6. Boxplots of estimated dependence of Salvelinus alpinus in total length $\left(L_{\mathrm{T}}\right)$ classes (a) 130-200 and (b) 200-350 mm in Saanajärvi, north-west Finland, on littoral energy sources $(Z)$ in different seasons. $Z$ estimates based on stable-isotope analysis of S. alpinus muscle $(\square)$ and liver $(\square)$ are shown. In the boxplots, lines indicate median, boxes show upper $(75 \%)$ and lower $(25 \%)$ quartiles and whiskers represent range (minimum and maximum values) with outliers indicated by $\bigcirc$. Number of fish analysed $(n)$ is shown above the bars.

(C) 2010 The Authors

Journal compilation $\odot 2010$ The Fisheries Society of the British Isles, Journal of Fish Biology 2010, 77, 80-97 
$n=30, P<0.05)$ and indicated the lower reliance of S. alpinus $200-350 \mathrm{~mm}$ on littoral energy sources in September compared with both April (Mann-Whitney $U$-test, $n=19, P<0.05$ ) and July (Mann-Whitney $U$-test, $n=24, P<0.01$ ).

\section{DISCUSSION}

The S. alpinus population in Saanajärvi clearly relies strongly on littoral production and benthic food resources, as indicated by both the generally small contribution of pelagic zooplankton in stomach contents and the relatively high stable isotopebased $Z$ estimates for most fish. A particularly strong reliance of $S$. alpinus and other fishes on littoral energy sources can be expected in high latitude lakes to be a consequence of the lakes' general ultraoligotrophy resulting in reduced planktonic resources (Sierszen et al., 2003) and of the more profitable foraging by adult fishes on larger littoral benthic macroinvertebrates than on small pelagic zooplankton (Forseth et al., 1994; Jansen et al., 2003; Karlsson \& Byström, 2005). Isotopic variation in S. alpinus from nine small Swedish subarctic lakes during winter indicated that these fish populations gained an average of $62-94 \%$ of their energy from littoral food webs (Karlsson \& Byström, 2005). The present study included a seasonal perspective and showed that a strong reliance on littoral energy sources by $S$. alpinus was evident throughout the year. Only the $Z$ estimates of S. alpinus $200-350 \mathrm{~mm}$ indicated a slight seasonal shift to more pelagic feeding in the late open-water season, which presumably reflects the seasonal increase in abundance of pelagic zooplankton. In Saanajärvi, pelagic crustacean zooplankton not only become more abundant (Rautio et al., 2000), but also develop a high lipid content in the late open-water season (J. Syväranta \& M. Rautio, unpubl. data), providing an alternative and energy-rich food resource for the fish. The lipid-rich pelagic zooplankton may also provide certain essential fatty acids needed for growth and reproduction (Marshall et al., 1999; Beaugrand et al., 2003).

Any slight pelagic niche shift of S. alpinus $200-350 \mathrm{~mm}$ was probably shortlived, since it was not detected in either the stomach contents or the $Z_{\text {muscle }}$ estimates. Because liver is as a regulatory tissue with continuous protein turnover, it can reveal dietary shifts of fishes with a much higher temporal resolution than muscle tissue, which, due to its slower isotopic turnover, generally reflects the main energy source during the previous months (Tieszen et al., 1983). Perga \& Gerdeaux (2005) found that the $\delta^{13} \mathrm{C}$ and $\delta^{15} \mathrm{~N}$ values of whitefish Coregonus lavaretus (L.) muscle only reflected the food consumed during the spring and summer growth period, whereas the isotope values of liver responded to seasonal changes in the isotope composition of the food sources. In Saanajärvi, the lower average values and greater individual variation in $\delta^{13} \mathrm{C}$ values and $Z$ estimates for $S$. alpinus liver are probably consequences of transient pelagic niche shifts by some individual fish, which did not manifest in the isotopic composition of muscle due to the markedly longer turnover rate of that tissue (Tieszen et al., 1983). Liver tissue may also contain more ${ }^{13} \mathrm{C}$-depleted lipids than muscle and thus have a lower $\delta^{13} \mathrm{C}$ value (Kiljunen et al., 2006). In Saanajärvi S. alpinus, however, the low C:N ratios of both muscle and liver tissue indicated that they contained only a little lipid (unpubl. data).

According to the $Z$ estimates, S. alpinus $130-200 \mathrm{~mm}$ in Saanajärvi had a more littoral trophic niche than the $200-350 \mathrm{~mm}$ fish and did not show a similar 
seasonal pelagic niche shift despite slight individual and seasonal differences in diet composition. The small 130-200 $\mathrm{mm}$ S. alpinus were probably more restricted to littoral habitat and prey because of the higher risk of predation in the pelagic habitat. Previous studies have shown that $S$. alpinus $\left(200-550 \mathrm{~mm} L_{\mathrm{T}}\right)$ mostly feed on fish prey of c. 30-240 $\mathrm{mm} L_{\mathrm{T}}$ (Amundsen, 1994; Hammar, 2000; Riget et al., 2000; Kahilainen \& Lehtonen, 2003), supporting the argument that in Saanajärvi, the S. alpinus of $>200 \mathrm{~mm} L_{\mathrm{T}}$ have largely outgrown the predation window of cannibals. Such a seasonal shift of intermediate-sized S. alpinus to pelagic feeding during summer or autumn, while the smaller conspecifics remain in the benthic habitat throughout the year, seems to be a rather widespread phenomenon that is often assumed to be due to different predation risks and abilities of individuals of different sizes to exploit seasonally abundant pelagic food resources (Sparholt, 1985; L'AbéeLund et al., 1993; Bjøru \& Sandlund, 1995). Amundsen et al. (2008) and Amundsen $\&$ Knudsen (2009), however, reported that $S$. alpinus of age $<5$ years and $L_{\mathrm{T}}$ of $<200 \mathrm{~mm}$ in the subarctic lake Fjellfrøsvatn, northern Norway, shifted to a more pelagic trophic niche in the late growing season (i.e. between August and December) despite the risk of predation by piscivorous $S$. trutta. Likewise, Svenning et al. (2007) found that despite the existence of cannibals, S. alpinus $<150 \mathrm{~mm}$ in Linnévatn, Svalbard, Norway, shifted from benthic to pelagic diet (i.e. copepods) in October, when chironomid larvae and pupae were few in number. The smaller contribution of littoral zone in Fjellfrøsvatn (c.30\% of lake area; Amundsen et al., 2008) and in Linnévatn ( $<10 \%$; Svenning et al., 2007) presumably results in lower littoral production compared with Saanajärvi (littoral zone 53\%) and may induce stronger seasonal habitat shift of small S. alpinus to the more risky pelagic niche. In Saanajärvi, no S. alpinus of $L_{\mathrm{T}}<100 \mathrm{~mm}$ or age of $<3$ years were captured, most likely because such fish were extremely sparse, and thus it is unknown whether S. alpinus in Saanajärvi shift from pelagic zooplankton to benthic prey during their early ontogeny.

Most of the S. alpinus $>500 \mathrm{~mm}$ in Saanajärvi had clearly undergone an ontogenetic dietary shift to cannibalism. In allopatric S. alpinus populations, an obligatory shift to piscivory (i.e. cannibalism) occurs at a relatively large size compared with multispecies fish communities, where availability of other small-sized prey fish species enables a shift to piscivory by individuals of $L_{\mathrm{T}} 100-200 \mathrm{~mm}$ and at the population level usually at $L_{\mathrm{T}}$ of 200-300 mm (L'Abée-Lund et al., 1992; Amundsen, 1994; Hammar, 2000; Kahilainen \& Lehtonen, 2003). The rather late shift to piscivory in Saanajärvi is probably related to the prevailing size structure of the fish population, where any $<100 \mathrm{~mm}$ fish may be quickly consumed by larger individuals (Polis, 1981; Amundsen, 1994; Byström, 2006). Instead of strict cannibalism, some of the $S$. alpinus $>500 \mathrm{~mm}$ probably retain a partly invertebrate diet, as suggested by the high individual variation in $\delta^{15} \mathrm{~N}$ signatures and also by the stomach contents of the one individual caught in July. McCarthy et al. (2004) proposed that the wide variation in $\delta^{15} \mathrm{~N}$ values observed in large piscivorous $S$. alpinus of Loch Ericht, Scotland, U.K., could result from individual differences in isotopic fractionation or feeding strategies with some individuals using only fishes and others switching between fishes and invertebrates. In Saanajärvi, some of the small S. alpinus had as high $\delta^{15} \mathrm{~N}$ values as $>500 \mathrm{~mm}$ fish probably due to their feeding on profundal chironomids with significantly higher $\delta^{15} \mathrm{~N}$ values compared with most littoral and pelagic prey organisms. The exceptionally high $\delta^{15} \mathrm{~N}$ values could also result from previous consumption of young-of-the-year (YOY) S. alpinus, which is probably a 
transient and quickly assimilated prey item and thus hard to detect in stomach contents. For instance, Hobson \& Welch (1995) found that in Char Lake, Northwest Territories, Canada, some intermediate-sized S. alpinus $(100-350 \mathrm{~mm})$ had unexpectedly high $\delta^{15} \mathrm{~N}$ signatures due to transient consumption of juvenile conspecifics of $L_{\mathrm{T}} 10-30 \mathrm{~mm}$ in addition to more common benthic prey.

The wide variety of prey items found in the stomach contents and the large individual variation in muscle and liver isotope values (Bearhop et al., 2004) both indicate that the S. alpinus population in Saanajärvi has a wide trophic niche. Individual specialization to different trophic niches (Amundsen, 1995) may partly explain the observed large variation in growth rates and condition factors, since there is no evidence of morphologically divergent S. alpinus morphs in Saanajärvi (Jonsson \& Jonsson, 2001) despite the successive stocking of Saanajärvi with fish from two different sources. Most likely the first set of released S. alpinus (translocated from Pahtajärvi in 1993) experienced relatively abundant resources and low competition and grew well. In contrast, the second set (translocated from Čuovgijávri in 1997) was released to a lake already inhabited by conspecifics, experienced reduced resources and stronger competition, and hence grew much more slowly. In any case, the stomach contents indicated that some individual $S$. alpinus had used pelagic crustacean zooplankton more extensively, while for the others zooplankton was only a minor food source supplementing the mainly benthivorous diet. Planktivory was probably only a temporary feeding strategy, because the relatively high $Z_{\text {liver }}$ and particularly $Z_{\text {muscle }}$ estimates of these individual fish indicated previous feeding on mainly littoral benthic prey.

In conclusion, the present study shows that a strong reliance of fishes on littoral energy sources can prevail throughout the year in high latitude lakes, presumably reflecting the relatively higher production and larger size of littoral prey organisms. Individual differences in feeding behaviour and extent of seasonal niche shift, however, are evident. Large cannibals show individual differences in the extent of piscivory and can retain invertebrates in their diet. Simultaneous use of stomach contents analysis and stable isotopes of fish muscle and liver proved especially suitable for studying the seasonal and ontogenetic shifts in fish diet and the energy flow through benthic and pelagic food webs to top consumers in a subarctic lake. Thus, liver could be used more in stable-isotope studies of fish trophic niche shifts due to its faster isotopic turnover rate than muscle and thus higher temporal resolution for dietary changes.

We thank Kilpisjärvi Biological Station for facilities and help during the field work, the Finnish Forest Research Institute for fishing licences and fish samples collected in April and J. Syväranta and M. Kiljunen for their practical help. This study was initiated with Academy of Finland grant 118587 to R.I.J. A.P.E. is also grateful to the Jenny and Antti Wihuri Foundation, the Ella and Georg Ehrnrooth Foundation and the Finnish Biological Society Vanamo for financial support. K.K.K. was financed by the Emil Aaltonen Foundation and the European Regional Development Fund (A30205).

\section{References}

Amundsen, P.-A. (1994). Piscivory and cannibalism in Arctic charr. Journal of Fish Biology 45, 181-189. doi: 10.1111/j.1095-8649.1994.tb01092.x

Amundsen, P.-A. (1995). Feeding strategy of Arctic charr (Salvelinus alpinus): general opportunist, but individual specialist. Nordic Journal of Freshwater Research 71, 150-156. 
Amundsen, P.-A. \& Knudsen, R. (2009). Winter ecology of Arctic charr (Salvelinus alpinus) and brown trout (Salmo trutta) in a subarctic lake, Norway. Aquatic Ecology 43 $765-775$.

Amundsen, P.-A., Bøhn, T., Popova, O. A., Staldvik, F. J., Reshetnikov, Y. S., Kashulin N. A. \& Lukin, A. A. (2003). Ontogenetic niche shifts and resource partitioning in a subarctic piscivore fish guild. Hydrobiologia 497, 109-119.

Amundsen, P.-A., Knudsen, R. \& Klemetsen, A. (2008). Seasonal and ontogenetic variations in resource use by two sympatric Arctic charr morphs. Environmental Biology of Fishes 83, 45-55.

Antonsson, Ú. (1992). The structure and function of zooplankton in Thingvallavatn, Iceland. Oikos 64, 188-211.

Battarbee, R. W., Thompson, R., Catalan, J., Grytnes, J. \& Birks, H. (2002). Climate variability and ecosystem dynamics of remote alpine and Arctic lakes: the MOLAR project. Journal of Paleolimnology 28, 1-6.

Bearhop, S., Adams, C. E., Waldron, S., Fuller, R. A. \& Macleod, H. (2004). Determining trophic niche width: a novel approach using stable isotope analysis. Journal of Animal Ecology 73, 1007-1012. doi: 10.1111/j.0021-8790.2004.00861.x

Beaugrand, G., Brander, K. M., Lindley, J. A., Souissi, S. \& Reid, P. C. (2003). Plankton effect on cod recruitment in the North Sea. Nature 426, 661-664.

von Bertalanffy, L. (1938). A quantitative theory of organic growth (inquiries on growth laws. II). Human Biology 10, 181-213.

Bjøru, B. \& Sandlund, O. T. (1995). Differences in morphology and ecology within a stunted Arctic char population. Nordic Journal of Freshwater Research 71, 163-172.

Bøhn, T. \& Amundsen, P.-A. (2001). The competitive edge of an invading specialist. Ecology 82, 2150-2163.

Byström, P. (2006). Recruitment pulses induce cannibalistic giants in Arctic char. Journal of Animal Ecology 75, 434-444. doi: 10.1111/j.1365-2656.2006.01064.x

Byström, P. \& Andersson, J. (2005). Size-dependent foraging capacities and intercohort competition in an ontogenetic omnivore (Arctic char). Oikos 110, 523-536. doi: 10.1111/j.0030-1299.2005.13543.x

Byström, P., Andersson, J., Persson, L. \& De Roos, A. M. (2004). Size-dependent resource limitation and foraging-predation risk trade-offs: growth and habitat use in young Arctic char. Oikos 104, 109-121. doi: 10.1111/j.0030-1299.2004.12759.x

Christoffersen, K. S., Jeppesen, E., Moorhead, D. L. \& Tranvik, L. J. (2008). Food-web relationships and community structures in high-latitude lakes. In Polar Lakes and Rivers: Limnology of Arctic and Antarctic Aquatic Ecosystems (Vincent, W. F. \& LaybournParry, J., eds), pp. 269-289. New York, NY: Oxford University Press.

Claessen, D., de Roos, A. M. \& Persson, L. (2000). Dwarfs and giants: cannibalism and competition in size-structured populations. American Naturalist 155, 219-237.

Damsgård, B. \& Ugedal, O. (1997). The influence of predation risk on habitat selection and food intake by Arctic charr, Salvelinus alpinus (L.). Ecology of Freshwater Fish 6 95-101. doi: 10.1111/j.1600-0633.1997.tb00149.x

Forseth, T., Ugedal, O. \& Jonsson, B. (1994). The energy budget, niche shift, reproduction and growth in a population of Arctic charr, Salvelinus alpinus. Journal of Animal Ecology 63, 116-126.

Forsström, L., Sorvari, S., Korhola, A. \& Rautio, M. (2005). Seasonality of phytoplankton in subarctic Lake Saanajärvi in NW Finnish Lapland. Polar Biology 28, 846-861.

Grey, J., Thackeray, S. J., Jones, R. I. \& Shine, A. (2002). Ferox trout (Salmo trutta) as 'Russian dolls': complementary gut content and stable isotope analyses of the Loch Ness foodweb. Freshwater Biology 47, 1235-1243. doi: 10.1046/j.1365-2427.2002.00838.x

Hammar, J. (1989). Freshwater ecosystems of polar regions: vulnerable resources. Ambio 18, $6-22$

Hammar, J. (2000). Cannibals and parasites: conflicting regulators of bimodality in high latitude Arctic char, Salvelinus alpinus. Oikos 88, 33-47.

Hecky, R. E. \& Hesslein, R. H. (1995). Contributions of benthic algae to lake food webs as revealed by stable isotope analysis. Journal of the North American Benthological Society 14, 631-653. 
Hindar, K. \& Jonsson, B. (1982). Habitat and food segregation of dwarf and normal Arctic charr (Salvelinus alpinus) from Vangsvatnet Lake, Western Norway. Canadian Journal of Fisheries and Aquatic Sciences 39, 1030-1045.

Hjelm, J., Persson, L. \& Christensen, B. (2000). Growth, morphological variation and ontogenetic niche shifts in perch (Perca fluviatilis) in relation to resource availability. Oecologia 122, 190-199.

Hobson, K. A. \& Welch, H. E. (1995). Cannibalism and trophic structure in a High Arctic lake: insights from stable-isotope analysis. Canadian Journal of Fisheries and Aquatic Sciences 52, 1195-1201.

Hynes, H. B. N. (1950). The food of fresh-water sticklebacks (Gasterosteus aculeatus and Pygosteus pungitius), with a review of methods used in studies of the food of fishes. Journal of Animal Ecology 19, 36-58.

Jansen, P. A., Finstad, A. G. \& Langeland, A. (2003). Size-scaling of zooplankton foraging in Arctic charr. Journal of Fish Biology 62, 860-870. doi: 10.1046/j.1095-8649.2003. 00071.x

Järvinen, A. (1987). Basic climatological data on the Kilpisjärvi area, NW Finnish Lapland. Kilpisjärvi Notes 10, 1-16.

Jonsson, B. \& Jonsson, N. (2001). Polymorphism and speciation in Arctic charr. Journal of Fish Biology 58, 605-638. doi: 10.1111/j.1095-8649.2001.tb00518.x

Kahilainen, K. \& Lehtonen, H. (2003). Piscivory and prey selection of four predator species in a whitefish dominated subarctic lake. Journal of Fish Biology 63, 659-672. doi: 10.1046/j.1095-8649.2003.00179.x

Kahilainen, K., Lehtonen, H. \& Könönen, K. (2003). Consequence of habitat segregation to growth rate of two sparsely rakered whitefish (Coregonus lavaretus (L.)) forms in a subarctic lake. Ecology of Freshwater Fish 12, 275-285. doi: 10.1046/j.16000633.2003.00029.x

Kalff, J. \& Welch, H. E. (1974). Phytoplankton production in Char Lake, a natural polar lake, and in Meretta Lake, a polluted polar lake, Cornwallis Island, Northwest Territories. Journal of the Fisheries Research Board of Canada 31, 621-636.

Karlsson, J. \& Byström, P. (2005). Littoral energy mobilization dominates energy supply for top consumers in subarctic lakes. Limnology and Oceanography 50, 538-543.

Kiljunen, M., Grey, J., Sinisalo, T., Harrod, C., Immonen, H. \& Jones, R. I. (2006). A revised model for lipid-normalizing $\delta^{13} \mathrm{C}$ values from aquatic organisms, with implications for isotope mixing models. Journal of Applied Ecology 43, 1213-1222. doi: 10.1111/ j.1365-2664.2006.01224.X

Klemetsen, A., Amundsen, P.-A., Dempson, J. B., Jonsson, B., Jonsson, N., O'Connell, M. F. \& Mortensen, E. (2003a). Atlantic salmon Salmo salar L., brown trout Salmo trutta L. and Arctic charr Salvelinus alpinus (L.): a review of aspects of their life histories. Ecology of Freshwater Fish 12, 1-59. doi: 10.1034/j.1600-0633.2003.00010.x

Klemetsen, A., Knudsen, R., Staldvik, F. J. \& Amundsen, P.-A. (2003b). Habitat, diet and food assimilation of Arctic charr under the winter ice in two subarctic lakes. Journal of Fish Biology 62, 1082-1098. doi: 10.1046/j.1095-8649.2003.00101.x

L'Abée-Lund, J. H., Langeland, A. \& Sægrov, H. (1992). Piscivory by brown trout Salmo trutta L. and Arctic charr Salvelinus alpinus (L.) in Norwegian lakes. Journal of Fish Biology 41, 91-101. doi: 10.1111/j.1095-8649.1992.tb03172.x

L'Abée-Lund, J. H., Langeland, A., Jonsson, B. \& Ugedal, O. (1993). Spatial segregation by age and size in Arctic charr: a trade-off between feeding possibility and risk of predation. Journal of Animal Ecology 62, 160-168.

Liboriussen, L. \& Jeppesen, E. (2003). Temporal dynamics in epipelic, pelagic and epiphytic algal production in a clear and a turbid shallow lake. Freshwater Biology 48, 418-431. doi: 10.1046/j.1365-2427.2003.01018.x

Marshall, C. T., Yaragina, N. A., Lambert, Y. \& Kjesbu, O. S. (1999). Total lipid energy as a proxy for total egg production in fish stocks. Nature 402, 288-290.

McCarthy, I. D., Fraser, D., Waldron, S. \& Adams, C. E. (2004). A stable isotope analysis of trophic polymorphism among Arctic charr from Loch Ericht, Scotland. Journal of Fish Biology 65, 1435-1440. doi: 10.1111/j.0022-1112.2004.00526.x

Perga, M. E. \& Gerdeaux, D. (2005). 'Are fish what they eat' all year round? Oecologia 144, 598-606. 
Polis, G. A. (1981). The evolution and dynamics of intraspecific predation. Annual Review of Ecology and Systematics 12, 225-251.

Polis, G. A., Anderson, W. B. \& Holt, R. D. (1997). Toward an integration of landscape and food web ecology: the dynamics of spatially subsidized food webs. Annual Review of Ecology and Systematics 28, 289-316.

Primicerio, R. \& Klemetsen, A. (1999). Zooplankton seasonal dynamics in the neighbouring lakes Takvatn and Lombola (northern Norway). Hydrobiologia 411, 19-29.

Rautio, M., Sorvari, S. \& Korhola, A. (2000). Diatom and crustacean zooplankton communities, their seasonal variability and representation in the sediments of subarctic Lake Saanajärvi. Journal of Limnology 59, 81-96.

Ricker, W. E. (1975). Computation and interpretation of biological statistics of fish populations. Bulletin of the Fisheries Research Board of Canada 191, 1-382.

Riget, F., Jeppesen, E., Landkildehus, F., Lauridsen, T. L., Geertz-Hansen, P., Christoffersen, K. \& Sparholt, H. (2000). Landlocked Arctic charr (Salvelinus alpinus) population structure and lake morphometry in Greenland - is there a connection? Polar Biology 23, 550-558.

Schindler, D. E. \& Scheuerell, M. D. (2002). Habitat coupling in lake ecosystems. Oikos 98, 177-189. doi: 10.1034/j.1600-0706.2002.980201.x

Schoener, T. W. (1970). Non-synchronous spatial overlap of lizards in patchy habitats. Ecology 51, 408-418.

Sierszen, M. E., McDonald, M. E. \& Jensen, D. A. (2003). Benthos as the basis for arctic lake food webs. Aquatic Ecology 37, 437-445.

Sparholt, H. (1985). The population, survival, growth, reproduction and food of Arctic charr, Salvelinus alpinus (L.), in four unexploited lakes in Greenland. Journal of Fish Biology 26, 313-330. doi: 10.1111/j.1095-8649.1985.tb04270.x

Svenning, M.-A. \& Borgstrøm, R. (1995). Population structure in landlocked Spitsbergen Arctic charr - sustained by cannibalism? Nordic Journal of Freshwater Research 71, $424-431$.

Svenning, M.-A. \& Borgstrøm, R. (2005). Cannibalism in Arctic charr: do all individuals have the same propensity to be cannibals? Journal of Fish Biology 66, 957-965. doi: 10.1111/j.0022-1112.2005.00646.x

Svenning, M.-A., Klemetsen, A. \& Olsen, T. (2007). Habitat and food choice of Arctic charr in Linnévatn on Spitsbergen, Svalbard: the first year-round investigation in a High Arctic lake. Ecology of Freshwater Fish 16, 70-77.

Tieszen, L. L., Boutton, T. W., Tesdahl, K. G. \& Slade, N. A. (1983). Fractionation and turnover of stable carbon isotopes in animal tissues: implications for $\delta^{13} \mathrm{C}$ analysis of diet. Oecologia 57, 32-37.

Vadeboncoeur, Y., Vander Zanden, M. J. \& Lodge, D. M. (2002). Putting the lake back together: reintegrating benthic pathways into lake food web models. Bioscience 52, $44-54$.

Vadeboncoeur, Y., Jeppesen, E., Vander Zanden, M. J., Schierup, H.-H., Christoffersen, K. \& Lodge, D. M. (2003). From Greenland to green lakes: cultural eutrophication and the loss of benthic pathways in lakes. Limnology and Oceanography 48, 1408-1418.

Vander Zanden, M. J. \& Rasmussen, J. B. (2001). Variation in $\delta^{15} \mathrm{~N}$ and $\delta^{13} \mathrm{C}$ trophic fractionation: implications for aquatic food web studies. Limnology and Oceanography $\mathbf{4 6}$, 2061-2066.

Vander Zanden, M. J. \& Vadeboncoeur, Y. (2002). Fishes as integrators of benthic and pelagic food webs in lakes. Ecology 83, 2152-2161.

Wallace, R. K. (1981). An assessment of diet-overlap indexes. Transactions of the American Fisheries Society 110, $72-76$

Welch, H. E. \& Kalff, J. (1974). Benthic photosynthesis and respiration in Char Lake. Journal of the Fisheries Research Board of Canada 31, 609-620.

Werner, E. E. \& Gilliam, J. F. (1984). The ontogenetic niche and species interactions in sizestructured populations. Annual Review of Ecology and Systematics 15, 393-425. 
Journal of Fish Biology (2010) 77, 1730

doi:10.1111/j.1095-8649.2010.02825.x, available online at wileyonlinelibrary.com

\section{Corrigendum}

Eloranta, A. P., Kahilainen, K. K., Jones, R. I. (2010). Seasonal and ontogenetic shifts in the diet of Arctic charr Salvelinus alpinus in a subarctic lake. Journal of Fish Biology 77, 80-97.

In the above paper there were errors in Figures 4 and 5. Please find the correct figures reproduced below

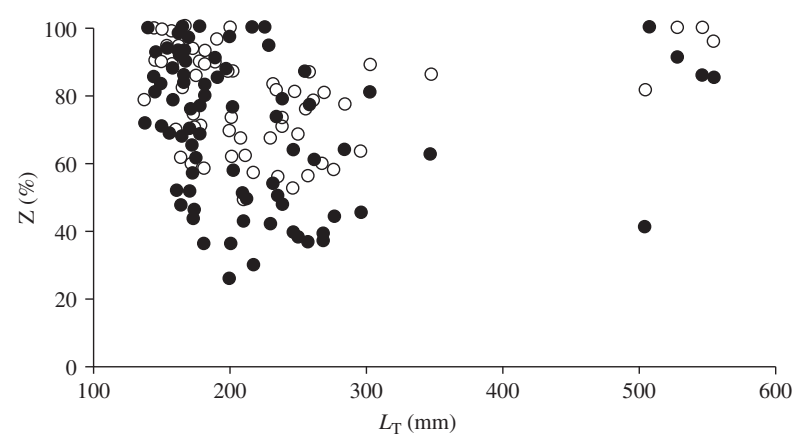

FIG. 4. Estimated dependence of Salvelinus alpinus $(n=79)$ in Saanajärvi, north-west Finland, on littoral energy sources $(Z)$ as a function of total length $\left(L_{\mathrm{T}}\right)$. $Z$ estimates based on stable-isotope analysis of $S$. alpinus muscle $(\mathrm{O})$ and liver $(\bullet)$ tissues are shown.

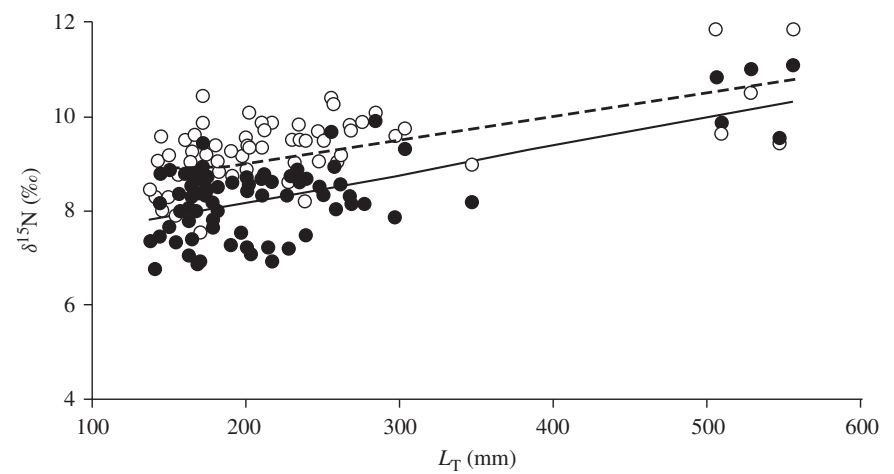

FIG. 5. $\delta^{15} \mathrm{~N}$ values of muscle $(\mathrm{O})$ and liver $(\bullet)$ tissues of Salvelinus alpinus in Saanajärvi, north-west Finland, as a function of total length $\left(L_{\mathrm{T}}\right)$. The curves were fitted by: muscle $y=0.005 x+8.018\left(r^{2}=0.388\right.$, $n=79, P<0.001)$ and liver $y=0.006 x+6.975\left(r^{2}=0.435, n=79, P<0.001\right)$. 


\section{DIETARY PLASTICITY OF ARCTIC CHARR (Salvelinus alpinus) FACILITATES COEXISTENCE WITH COMPETITIVELY SUPERIOR EUROPEAN WHITEFISH (Coregonus lavaretus)}

Ecology of Freshwater Fish 20: 558-568.

Reprinted with kind permission of John Wiley and Sons (C) 


\section{Dietary plasticity of Arctic charr (Salvelinus} alpinus) facilitates coexistence with competitively superior European whitefish (Coregonus lavaretus)

Antti P. Eloranta ${ }^{1}$, Anna Siwertsson ${ }^{2}$, Rune Knudsen ${ }^{2}$, Per-Arne Amundsen ${ }^{2}$

${ }^{1}$ Department of Biological and Environmental Sciences, University of Jyväskylä, Jyväskylä, Finland

${ }^{2}$ Department of Arctic and Marine Biology, Faculty of Biosciences, Fisheries and Economics, University of Tromsø, Tromsø, Norway

Accepted for publication March 30, 2011

Abstract - Habitat use and diet of Arctic charr (Salvelinus alpinus) coexisting with European whitefish (Coregonus lavaretus) and grayling (Thymallus thymallus) were studied in one deep and two relatively shallow subarctic lakes in northern Norway. Stomach content and stable isotope analyses revealed clear and temporally stable resource partitioning between the species in all three lakes. Arctic charr had a wide and flexible trophic niche and was the only piscivorous species. In contrast, whitefish and grayling had remarkably stable planktivorous and benthivorous niches, respectively. In the deepest lake, Arctic charr together with grayling mainly utilised littoral benthos, while piscivory was more prevalent in Arctic charr in the two shallower lakes. In one of the shallow lakes, whitefish was apparently relegated to the inferior profundal niche because of dominance of the littoral by grayling. Our results suggest that Arctic charr may not necessarily need an extensive profundal zone as a refuge, but can coexist with whitefish if a third competing fish species like grayling occurs in the littoral habitat or if profitable small prey fish are available. The study demonstrates that strong dietary plasticity of Arctic charr is instrumental in the observed coexistence with the commonly competitively superior whitefish.

Key words: diet; resource partitioning; stable isotope analysis; subarctic lakes; trophic niche

\section{Introduction}

As the natural distributions of many species extend towards higher latitudes and altitudes because of global warming (Walther et al. 2002), a major concern for aquatic ecosystems is invasive species and their impacts on native fish populations (Lehtonen 1996; Graham \& Harrod 2009). The most common native fish species in high-latitude lakes is Arctic charr (Salvelinus alpinus), which is regarded as a poor resource competitor against sympatric fish species (e.g., Klemetsen et al. 2003). Serious declines or local extinction of many Arctic charr populations is observed in northern Europe and in the British Isles as a result of introductions or invasions of new fish species as well as other disturbances (Nilsson 1965;
Winfield et al. 2010). Deeper understanding of the mechanisms facilitating the stable coexistence of Arctic charr and their potential resource competitors is essential for future management and conservation strategies (Maitland 1995; Corrigan et al. 2011).

European whitefish (Coregonus lavaretus) is one of the most widely introduced fish species in northern Europe and has partially or completely displaced many native Arctic charr populations, evidently because of its better ability to utilise pelagic food resources (Nilsson \& Pejler 1973; Svärdson 1976). When living in sympatry with benthivorous fish species, such as brown trout (Salmo trutta) or burbot (Lota lota), Arctic charr are often forced to utilise zooplankton or profundal benthos (Langeland et al. 1991; Knudsen et al. 2010). There are some large deep lakes in

Correspondence: A. P. Eloranta, Department of Biological and Environmental Sciences, University of Jyväskylä, P0 Box 32, FIN-40014 Jyväskylä, Finland; Tel.: +358 14260 4237; Fax: +358 14260 2321. E-mail: antti.eloranta@jyu.fi 
Fennoscandia and elsewhere where Arctic charr and whitefish naturally coexist, because the large profundal zone offers a refuge for the competitively inferior Arctic charr (Svärdson 1976; Sandlund et al. 2010). However, in small shallow lakes, Arctic charr presumably need other strategies to be able to coexist with sympatric whitefish.

In some subarctic lakes, Arctic charr and whitefish coexist together with European grayling (Thymallus thymallus). All three species have a generalist feeding behaviour, but in allopatry usually prefer the littoral feeding habitat because of the higher availability of large-sized benthic prey (Nilsson 1965; Northcote 1995; Amundsen et al. 2004). However, in sympatry, these fish species likely alter their foraging behaviour to diminish niche overlap, which otherwise could lead to competitive exclusion of the inferior species (Hardin 1960; Nilsson 1967). Congruent with this theory, Amundsen et al. (2010) found distinct resource partitioning between the species in Lake Biggijavri, northern Norway, with Arctic charr and grayling occupying different littoral niches and whitefish utilising the pelagic habitat and food resources Amundsen et al. (2010) suggested that the stable coexistence of Arctic charr and whitefish could be facilitated by the presence of sympatric grayling forcing whitefish to utilise primarily the planktivorou niche. This suggestion is supported by the theoretica model developments of Abrams \& Rueffler (2009) arguing that coexistence of three competing species may occur if the intermediate species (i.e., Arctic charr) is more similar in niche use to one of the others (i.e., grayling). However, in shallow lakes with small profundal and pelagic areas, Arctic charr and whitefish have lower ability for resource partitioning. In such lakes, the higher potential of Arctic charr to piscivory (L'Abée-lund et al. 1992; Amundsen 1994) may potentially help to escape interspecific interactions from planktivorous whitefish as well as from benthivorous species like grayling. Thus, the availability of small-sized prey fish species may suggestively favour the coexistence of Arctic charr and whitefish (Svärdson 1976; Kahilainen \& Lehtonen 2002).

Here, we studied the habitat use and diet of Arctic charr coexisting naturally with both whitefish and grayling in three near-pristine lakes in subarctic Norway. We extended the study of Amundsen et al. (2010) by analysing stable carbon $\left(\delta^{13} \mathrm{C}\right)$ and nitroge $\left(\delta^{15} \mathrm{~N}\right)$ isotope ratios from fish muscle tissue to trace the long-term niche use of the three species. The stomach contents reveal the recently ingested prey items, whereas the carbon and nitrogen stable isotope ratios reflect the assimilated food sources and the trophic position of fish over several months (Fry 2006 Buchheister \& Latour 2010). By combining these methods and data collected from one relatively deep
$\left(Z_{\mathrm{mx}}=52 \mathrm{~m}\right)$ and two shallower lakes $\left(Z_{\max }=12\right.$ and $17 \mathrm{~m})$, we were able to explore the temporal and spatial stability of the possible resource partitioning between the three fish species. We hypothesised that resource partitioning between Arctic charr, whitefish and grayling should be evident: (i) in all the study lakes despite differences in lake maximum depth, and (ii) from both stomach contents and stable isotopes results, demonstrating temporal stability of niche segregation. Finally, we hypothesised (iii) that high dietary plasticity of Arctic charr facilitates the observed species coexistence.

\section{Methods}

Study site

The three study lakes, Biggijavri $\left(69^{\circ} 33^{\prime} \mathrm{N}, 23^{\circ} 46^{\prime} \mathrm{E}\right)$, Vuolit Spielgajavri $\left(69^{\circ} 26^{\prime} \mathrm{N}, 23^{\circ} 33^{\prime} \mathrm{E}\right)$ and Datkujavri $\left(69^{\circ} 29^{\prime} \mathrm{N}, 23^{\circ} 26^{\prime} \mathrm{E}\right)$, are all oligotrophic and slightly humic lakes located at different altitudes along the Mazejokka tributary of the Kautokeino-Alta watercourse in northern Norway. Biggijavri is the deepest, largest and most oligotrophic lake, but otherwise, the lakes have rather similar physical and chemical (measured by the University of Tromsø) characteristics (Table 1). The lakes are dimictic and usually ice-free from June to October. The catchment area (approximately $120 \mathrm{~km}^{2}$ in total) consists mainly of mountain birch forest and bogs. The fish communities are dominated by whitefish, Arctic charr and grayling, whereas burbot (Lota lota), brown trout (Salmo trutta), pike (Esox lucius) and European minnow (Phoxinus phoxinus) are present in relatively low densities. Arctic charr and whitefish occur as monomorphic populations in all the study lakes. No considerable fishery or any stocking activity is occurring in the lakes.

\section{Habitat and stomach content analyses}

Samples were collected from Biggijavri in 1st-3rd September 2008, from Vuolit Spielgajavri in 4th6th September 2008 and from Datkujavri in 7th-8th September 2009 (Table 1). Fish were sampled in littoral, profundal and pelagic habitats using 40-mlong survey gill nets composed of eight randomly distributed 5-m panels of $10,12.5,15,18.5,22,26,35$ and $45 \mathrm{~mm}$ bar mesh sizes. In the littoral and profundal sampling sites, $1.5-\mathrm{m}$-deep bottom nets (9-13 per lake) were used, whereas 6-m-deep floating nets ( 2 per lake) were used in the pelagic zone in each lake (1-2 nights per lake). Some additional fish for the stomach content and stable isotope analyses were sampled using 30-m-long and 1.5-m-deep single mesh-sized $(20,22,26,32,35 \mathrm{~mm})$ gill nets $(3-5$ 


\section{Eloranta et al.}

Table 1. Information about (a) physical and chemical characteristics of the study lakes, and (b) sample sizes and mean (range in parentheses) fork length (FL) of Arctic charr, whitefish and grayling collected with survey gill nets from Bigajari, Vuolit Spielgajuri and Datkujavri. The sample sizes for stomacts stomach conts parentheses (see Methods for more details about sampling).

\begin{tabular}{|c|c|c|c|}
\hline & Biggijavri & $\begin{array}{l}\text { Vuolit } \\
\text { Spielgajavri }\end{array}$ & Datkujavri \\
\hline \multicolumn{4}{|l|}{ (a) } \\
\hline Altitude (m a.s.l.) & 381 & 436 & 474 \\
\hline Area $\left(\mathrm{km}^{2}\right)$ & 5.4 & 3.3 & 4.2 \\
\hline Maximum depth (m) & 52 & 12 & 17 \\
\hline Conductivity $\left(\mu \mathrm{S} \cdot \mathrm{cm}^{-1}\right)$ & 31 & 34 & 34 \\
\hline $\mathrm{pH}$ & 7.1 & 7.2 & 7.4 \\
\hline Total $\mathrm{P}\left(\mu \mathrm{g} \cdot \mathrm{I}^{-1}\right)$ & 3 & 18 & 11 \\
\hline Total N $\left(\mu \mathrm{g} \cdot \mathrm{I}^{-1}\right)$ & 148 & 296 & 240 \\
\hline TOC $\left(\mu \mathrm{g} \cdot \mathrm{I}^{-1}\right)$ & 4 & 4.8 & 2.1 \\
\hline Colour (mg.Pt. $\mathrm{I}^{-1}$ ) & 10 & 10 & 10 \\
\hline Secchi depth (m) & 8 & 6 & 7.5 \\
\hline \multicolumn{4}{|l|}{ (b) } \\
\hline \multicolumn{4}{|l|}{ Sample size } \\
\hline Arctic charr & $31(38 ; 37)$ & $15(24 ; 24)$ & $12(12 ; 12)$ \\
\hline Whitefish & $113(108 ; 73)$ & $157(99 ; 72)$ & $94(112 ; 84)$ \\
\hline Graying & $37(28 ; 16)$ & $172(44 ; 41)$ & $85(68 ; 33)$ \\
\hline \multicolumn{4}{|l|}{ Mean (range) } \\
\hline FL (mm) & & & \\
\hline Arctic charr & $233(133-343)$ & 257 (100-488) & $375(223-493)$ \\
\hline Whitefish & $221(96-347)$ & $240(123-367)$ & $247(113-330)$ \\
\hline Graying & $251(117-368)$ & $263(117-480)$ & $290(117-418)$ \\
\hline
\end{tabular}

per lake). To study the density and habitat use of Arctic charr, whitefish and grayling, catch per unit effort (CPUE; number of fish caught per $100 \mathrm{~m}^{2}$ survey gill net per night) was estimated for each fish species at each sampling occasion from the littoral, profundal and pelagic habitats.

After removal from the gill nets, fish were kept cool and brought to the field laboratory, where they were identified, measured (fork length, $\mathrm{mm}$ ) and weighed $(\mathrm{g})$. The stomachs were removed and preserved in $96 \%$ ethanol until subsequent analysis. Later, the stomachs were opened, and the total fullness was visually determined on a percentage scale ranging from empty $(0 \%)$ to full $(100 \%)$. The prey items were identified to species, genus or family level, and their contribution to the total fullness was estimated (Amundsen et al. 1996). The prey taxa were subsequently grouped into (i) cladoceran zooplankton (Bosmina sp., Daphnia sp., Holopedium gibberum, Bythotrephes longimanus, Polyphemus sp.) and (ii) copepod zooplankton (Cyclops scutifer, Eudiaptomus sp., Acanthocyclops sp.), (iii) adult and pupal stages of aquatic and terrestrial insects, (iv) chironomid larvae, (v) Trichoptera larvae, (vi) other insect larvae (Megaloptera, Ephemeroptera, Plecoptera, Tipulidae sp.), (vii) Gammarus lacustris amphipods, (viii) Eurycercus lamellatus chydorids, (ix) clams (Pisidium sp., Sphaerium sp.), (x) snails
(Lymnaea sp., Valvata sp., Planorbidae sp.) and (xi) fish. Cladoceran and copepod zooplankton were considered as pelagic prey, whereas all benthic invertebrates were considered as littoral prey. However, chironomid larvae and pupae and clams can either have a littoral or profundal origin and thus represent different energy sources for the fish. In the same way, adult insects include both aquatic (e.g. chironomids, Trichoptera, Tipulidae sp.) and terrestrial (e.g., Hymenoptera) species, which can have clearly different isotope values.

The habitat and dietary overlap between Arctic charr, whitefish and grayling were estimated using Schoener's (1970) similarity index:

$$
\alpha=1-0.5\left(\sum_{i=1}^{n}\left|P_{x i}-P_{y i}\right|\right)
$$

where $P_{x i}$ is the proportion of habitat/prey group $i$ used by species $x, P_{y i}$ is the proportion of habitat/prey group $i$ used by species $y$, and $n$ is the number of habitat/prey categories. The same index was also used to estimate species-specific similarities in habitat and diet use between the lakes. The overlap/similarity is considered high when the index value exceeds $60 \%$ (Wallace 1981). The dietary niche width $(B)$ was calculated using Levins (1968) index:

$$
B=1 / \sum p_{i}^{2}
$$

where $p_{i}$ is the proportion of each prey type $i$ in the diet expressed as fraction rather than percentage.

\section{Stable isotope analyses}

For stable isotope analysis of carbon and nitrogen, a small block of white dorsal muscle tissue posterior to the dorsal fin was dissected from fresh subsamples of fish (Table 1) and stored at $-20{ }^{\circ} \mathrm{C}$ until later preparation. The muscle samples were dried at $60{ }^{\circ} \mathrm{C}$ for $48 \mathrm{~h}$ and ground to a fine powder using a mortar and pestle. In addition, qualitative samples of littoral (depth $<2 \mathrm{~m}$ ) and profundal (depth $12-30 \mathrm{~m}$ ) benthic macroinvertebrates (hereafter benthos) and zooplankton (several vertical hauls from 10 to $0 \mathrm{~m}$ ) were collected and prepared for isotope analyses. Animals were sorted to genus level, dried at $60{ }^{\circ} \mathrm{C}$ for $48 \mathrm{~h}$ and ground using an iron bar or a mortar and pestle. From molluscs, only the soft body tissue was prepared for later stable isotope analyses. Isotopic analyses of carbon and nitrogen were mainly carried out at the Institute for Environmental Research, University of Jyväskylä, Finland, using a FlashEA 1112 elemental analyser coupled to a Thermo Finnigan DELTA $^{\text {plus }}$ Advantage mass spectrometer (Thermo Fisher Scientific, Waltham, MA, USA). Some isotope 


\section{Coexistence of Arctic charr and whitefish}

samples from Biggijavri were analysed at the NERC Life Sciences Mass Spectrometry Facility, East Kilbride, Scotland, by continuous flow isotope ratio mass spectrometry (CF-IRMS) using a Costech ECS 4010 elemental analyser interfaced with a Thermo Fisher Scientific Delta XP Plus IRMS. We checked the consistency of the instruments by analysing $\delta^{13} \mathrm{C}$ and $\delta^{15} \mathrm{~N}$ values from a fish standard (i.e., whitefish muscle tissue) and found no significant differences. Isotope ratios are expressed as values in parts per thousands $(\%)$, and differences from a standard reference material are calculated as:

$$
X=10^{3}\left(R_{\text {sample }}-R_{\text {standard }}\right) R_{\text {standard }}^{-1}
$$

where $X$ is $\delta^{13} \mathrm{C}$ or $\delta^{15} \mathrm{~N}, R_{\text {sample }}$ is the corresponding ratio ${ }^{13} \mathrm{C}:{ }^{12} \mathrm{C}$ or ${ }^{15} \mathrm{~N}:{ }^{14} \mathrm{~N}$, and $R_{\text {stand }}$ is the ratio of the international references Vienna PeeDee Belemnite (vPDB) for carbon and atmospheric nitrogen for nitrogen. The analysed $\mathrm{C}: \mathrm{N}$ values, which are positively correlated with the lipid content of sample, indicated no need for lipid adjustment of $\delta^{13} \mathrm{C}$ values (see Kiljunen et al. 2006).

The $\delta^{13} \mathrm{C}$ and $\delta^{15} \mathrm{~N}$ values of Arctic charr, whitefish and grayling were compared within each lake using nonparametric Kruskal-Wallis and Mann-Whitney $U$ tests as assumptions for parametric tests were not met. The same statistical tests were used to compare the total length of Arctic charr, whitefish and grayling within each lake and between the lakes. In addition, the recently developed isotope mixing model Stable Isotope Analysis in R (SIAR; Parnell et al. 2010) was employed to estimate the relative contributions of littoral and profundal benthos and zooplankton in the diets of Arctic charr, whitefish and grayling. For Arctic charr, fish were also included as a food source by combining all the available isotope data from small prey fish (i.e., minnows and burbots of fork length 80 $172 \mathrm{~mm}$ ). The SIAR model utilises a Bayesian approach to estimate source contribution and incorporates isotopic variability both in the consumer and in the food sources. SIAR has recently been successfully used in estimations of littoral, profundal and pelagic diet contributions for whitefish populations in northern Finland (Harrod et al. 2010). Here, modelling the diets of Arctic charr, whitefish and grayling in SIAR was enabled by the clear isotopic separation between littoral, profundal and pelagic invertebrates and small fish (Fig. 5). Trophic enrichment factors of $1.0 \pm 1.0 \%$ for $\delta^{13} \mathrm{C}$ and $3.3 \pm 1.0 \%$ for $\delta^{15} \mathrm{~N}$ were chosen to correspond to the most often reported and used factors (Vander Zanden \& Rasmussen 1999; Post 2002) and to incorporate the variation of fractionation values observed in a meta-analysis (McCutchan et al. 2003). Concentrations of carbon and nitrogen were also incorporated into the SIAR model despite only minor differences between the food sources (total range $47-53 \%$ for carbon and $7-13 \%$ for nitrogen). To investigate the dietary plasticity and trophic niche width of Arctic charr, whitefish and grayling in each lake, we calculated the areas encompassing the individuals of each species in the $\delta^{13} \mathrm{C}-\delta^{15} \mathrm{~N}$ bi-plot space (cf. Fig. 4) using the 'Minimum Convex Polygon Estimator' in the 'adehabitat' package in R (Calenge 2006). Instead of calculating total convex hull areas encompassing the isotope values of all individuals (cf. Layman et al. 2007), we restricted the isotopic niche areas to bound $95 \%$ of the individuals of each species to exclude possible outliers, which could potentially overextend the niche areas. All statistical analyses were performed using PASW Statistics 18 for Windows (SPSS Inc., Chicago, IL, USA) and R 2.10.1 (R Development Core Team 2009).

\section{Results}

Niche segregation between the species

A total of 73 Arctic charr, 382 whitefish, 294 grayling, 21 burbot, two minnow and two brown trout were caught with the survey and single mesh-sized gill nets from the three study lakes. The Arctic charr catch (CPUE) was relatively low compared to whitefish and grayling, but substantially higher compared to other fish species (Fig. 1). The Arctic charr CPUE was highest in Biggijavri, although the total CPUE for all fish species was higher in Vuolit Spielgajavri and Datkujavri. In Biggijavri and Vuolit Spielgajavri, the sampled Arctic charr, whitefish and grayling were all about the same size except that grayling were slightly larger than whitefish in Vuolit Spielgajavri (MannWhitney test: $P=0.003$; Table 1$)$. The three species differed significantly in total length in Datkujavri (Kruskal-Wallis test: $P<0.001$ ), where Arctic charr were on average larger than whitefish and grayling (Mann-Whitney tests: $P<0.001$ ), and grayling were slightly larger than whitefish (Mann-Whitney test: $P<0.001)$. The total length of Arctic charr also differed between the lakes (Kruskal-Wallis test: $P<0.001)$ as they were significantly larger in Datkujavri than in Biggijavri (Mann-Whitney test: $P<0.001$ ) and Vuolit Spielgajavri (Mann-Whitney test: $P=0.002$ ).

Arctic charr preferred the littoral and profundal habitats in all lakes, and only few individuals were caught in the pelagic zone (Fig. 1). Whitefish used all main habitats and were the only fish species caught frequently in the pelagic zone. In contrast, grayling were almost exclusively caught in the littoral zone and thus exhibited distinct habitat segregation from whitefish in all three lakes (Fig. 2). Arctic charr and 
Eloranta et al.

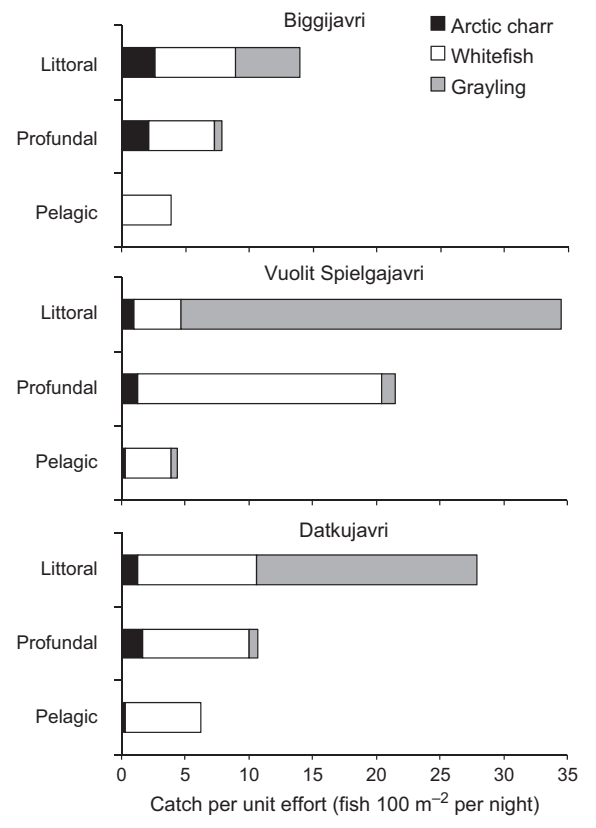

Fig. 1. Catch per unit effort (number of fish caught per $100 \mathrm{~m}^{2}$ survey gill net per night) of Arctic charr, whitefish and grayling in the littoral, profundal and pelagic habitats of Biggijavri, Vuolit Spielgajavri and Datkujavri. whitefish showed overlapping habitat utilisation in all three lakes despite a generally more pronounced pelagic habitat use by whitefish. Arctic charr and grayling exhibited overlapping habitat use in Biggijavri, whereas there was clear habitat segregation between these two species in the other lakes.

The three fish species showed clear dietary segregation in all three lakes (Fig. 2). The highest diet similarity was observed between Arctic charr and grayling in Biggijavri and Vuolit Spielgajavri, where they both fed substantially on Trichoptera larvae (Fig. 3). However, the dietary overlap was not marked as Arctic charr also fed substantially on fish (minnows and burbots) and snails (particularly Lymnaea sp.), and partly also on zooplankton. Hence, Arctic charr showed a wider trophic niche than grayling and whitefish in Biggijavri and Vuolit Spielgajavri (Fig. 3). Whitefish had a distinct pelagic niche with a diet mainly consisting of planktonic cladocerans and copepods. The semi-benthic chydorid E. lamellatus was also an important food for whitefish, particularly in Biggijavri and Datkujavri. In all lakes, grayling was rather strictly specialised in littoral prey by consuming mainly Trichoptera larvae as well as adult and pupal stages of insects.

\section{Between-lake differences in habitat use and diet}

Arctic charr, whitefish and grayling showed similar habitat utilisation in all three lakes (Fig. 2) despite an extensive profundal habitat use by whitefish in Vuolit

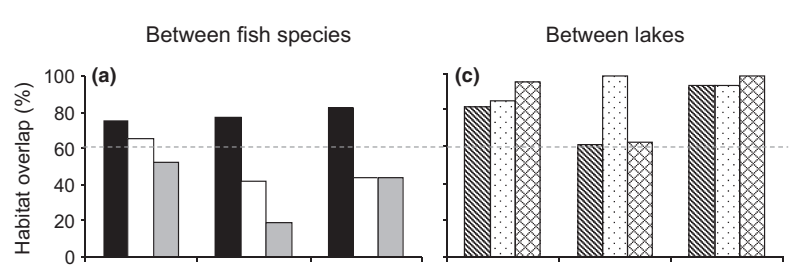

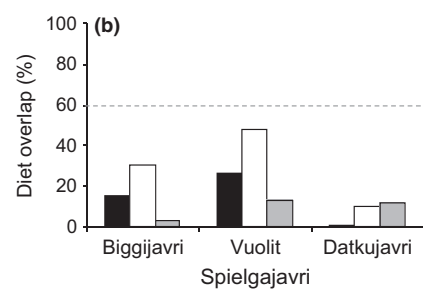

Arctic charr versus Whitefish

$\square$ Arctic charr versus Grayling

$\square$ Whitefish versus Grayling (d)

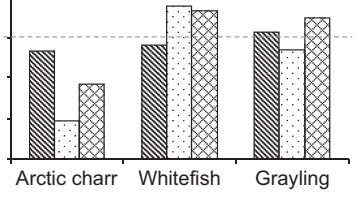

$\mathbb{N}$ Biggijavri versus Vuolit Spielgajavri $\square$ Biggijavri versus Datkujavri

Vuolit Spielgajavri versus Datkujavri
Fig. 2. Between-species overlaps in (a) habitat use and (b) diet (per cent overlap index) and between-lake similarity comparisons of (c) habitat use and (d) diet of Arctic charr, whitefish and grayling from Biggijavri, Vuolit Spielgajavri and Datkujavri. The overlap/similarity is considered high when the index value exceeds $60 \%$ (dig line). The dietary overlaps/similashe line). The dietary overlaps/similarities are Fig. 3. 
Coexistence of Arctic charr and whitefish
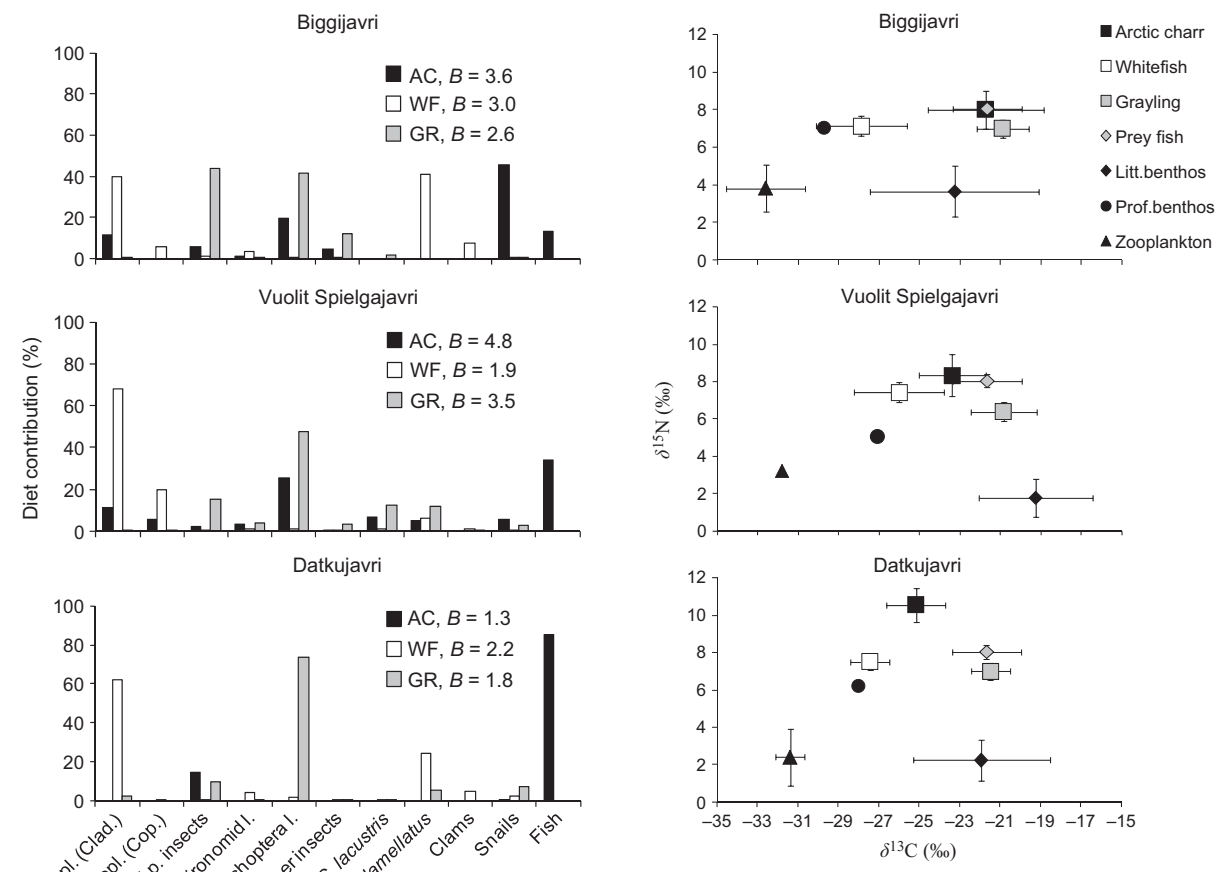

Fig. 4. The mean $( \pm \mathrm{SD}) \delta^{15} \mathrm{~N}$ and $\delta^{13} \mathrm{C}$ values of muscle tissue from Arctic charr, whitefish and grayling, and of littoral benthos (Litt. benthos), profundal benthos (Prof. benthos), zooplankton and prey fish (minnows and small-sized burbots) sampled from Biggijavri, Vuolit Spielgajavri and Datkujavri. width (Levin's index $B$ ) for Arctic charr (AC), whitefish (WF) and grayling (GR) in Biggijavri, Vuolit Spielgajavri and Datkujavri. The dietary niche width estimates are based on the 11 prey categories presented in the figure. Abbreviations: Zoopl. $($ Clad. $)=$ cladoceran zooplankton, Zoopl. $($ Cop. $)=$ copepod zooplankton, Ad. \& p. insects = adult and pupal stages of insects, Chironomid $1 .=$ chironomid larvae, Trichoptera $1 .=$ Trichoptera larvae, G. lacustris = Gammarus lacustris amphipod, E. lamellatus $=$ Eurycercus lamellatus chydorid.

Spielgajavri. In contrast, the diet of Arctic charr differed substantially between the lakes. The relatively large-sized Arctic charr in Datkujavri were mainly piscivores compared to the more generalistic conspecifics in Biggijavri and Vuolit Spielgajavri, which mainly consumed different kinds of benthic and pelagic prey (Fig. 3). No major between-lake differences were evident for whitefish and grayling (Fig. 2), mainly because of their consistent utilisation of cladoceran zooplankton and Trichoptera larvae, respectively (Fig. 3). The only notable dietary differences were observed between whitefish from Biggijavri and Vuolit Spielgajavri with the former feeding substantially more on the semi-benthic E. lamellatus,

and between grayling from Biggijavri and Datkujavri because of larger dietary contributions of adult and pupal stages of insects in Biggijavri and Trichoptera larvae in Datkujavri.

Stable isotope analyses

There were significant differences in the isotopic compositions between Arctic charr, whitefish and grayling in all three lakes (Kruskal-Wallis tests for $\delta^{13} \mathrm{C}$ and $\left.\delta^{15} \mathrm{~N}: P<0.001\right)$. The three species differed in isotope values in all lakes except Biggijavri, where Arctic charr and grayling had similar $\delta^{13} \mathrm{C}$ values (Mann-Whitney test: $P=0.614$ ) and whitefish and grayling had similar $\delta^{15} \mathrm{~N}$ values (Mann-Whitney test: $P=0.701)$. In general, Arctic charr had $\delta^{13} \mathrm{C}$ values intermediate between whitefish and grayling, the former having significantly lower (i.e., more pelagic) and the latter significantly higher (i.e., more littoral) $\delta^{13} \mathrm{C}$ values compared to the two other fish species 
Eloranta et al.
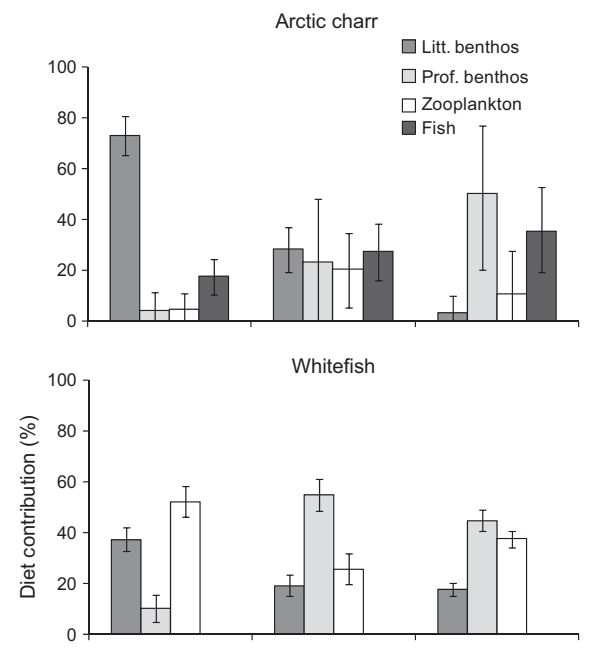

Grayling

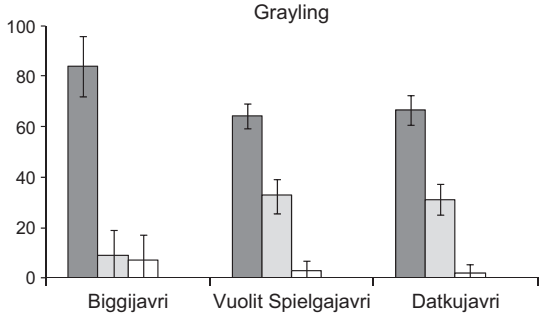

Fig. 5. Estimated mean ( $\pm 95 \%$ Bayesian credibility intervals) contributions of littoral and profundal benthos, zooplankton and fish in the diets of Arctic charr, whitefish and grayling caught from Biggijavri, Vuolit Spielgajavri and Datkujavri. The estimates are based on $\delta^{15} \mathrm{~N}$ and $\delta^{13} \mathrm{C}$ values analysed from the fish muscle tissue and from the potential food sources.

(Fig. 4). Arctic charr also differed from whitefish and grayling by their higher $\delta^{15} \mathrm{~N}$ values, indicating a higher trophic position. This was particularly evident in Datkujavri where Arctic charr had on average 3\% higher $\delta^{15} \mathrm{~N}$ value compared to the other two fish species.

The results of the SIAR isotope mixing model broadly corresponded to the habitat and dietary data. In particular, the SIAR confirmed the distinct niche segregation between whitefish and grayling by demonstrating a strong reliance on pelagic versus littoral food sources, respectively (Fig. 5). Furthermore, the model revealed clear between-lake differences for Arctic charr with littoral benthos dominating in Biggijavri and fish and profundal benthos in Vuolit
Spielgajavri and Datkujavri. According to both SIAR and stomach contents, Arctic charr had the most generalist diet in Vuolit Spielgajavri.

The minimum convex polygons in $\delta^{13} \mathrm{C}-\delta^{15} \mathrm{~N}$ bi-plot space indicated a wide trophic niche for Arctic charr, particularly in Biggijavri where the individual isotope values for Arctic charr encompass an area over threefold compared to whitefish or grayling (Fig. 6). The convex polygons of the three species were most distinct in Datkujavri and most overlapping in Vuolit Spielgajavri, where Arctic charr and whitefish had only slightly larger niches compared to grayling. In all lakes, most whitefish had clustered together in a pelagic niche as denoted by their low $\delta^{13} \mathrm{C}$ values, whereas grayling dominated the littoral niche.

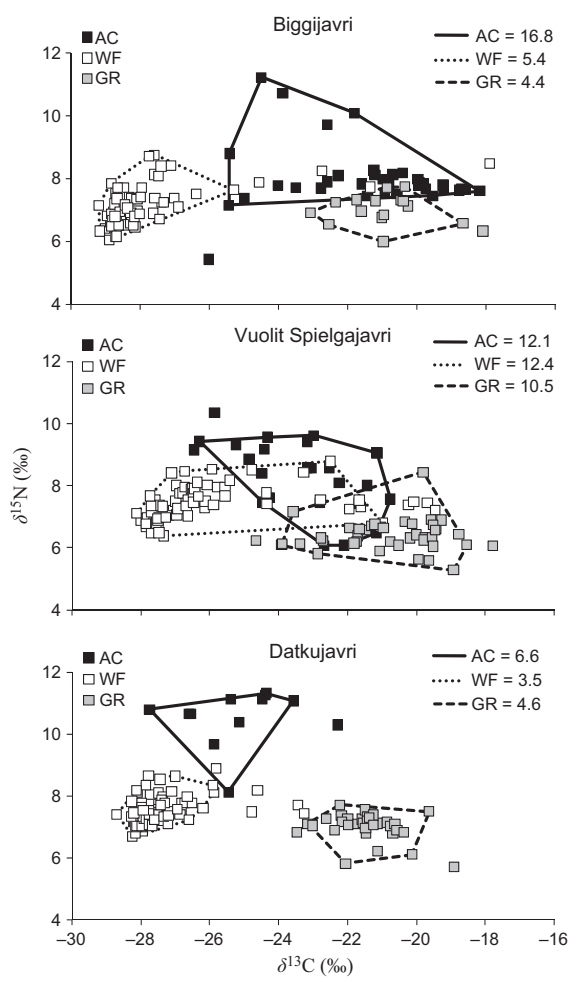

Fig. 6. Minimum convex polygons (lines) in $\delta^{13} \mathrm{C}-\delta^{15} \mathrm{~N}$ bi-plot space encompassing $95 \%$ of individual (symbols) Arctic charr (AC), whitefish (WF) and grayling (GR) from Biggijavri, Vuolit Spielgajavri and Datkujavri. The calculated areas of isotopic niches for Arctic charr, whitefish and grayling are also shown. 


\section{Discussion}

We found a distinct resource partitioning between Arctic charr, whitefish and grayling in all three study lakes despite differences in lake maximum depth. The congruent results of the stomach content and stable isotope analyses indicate temporal stability of the niche segregation and demonstrate a high dietary plasticity of Arctic charr, which likely facilitates the coexistence of this species with whitefish and grayling. Arctic charr showed in general the widest trophic niche of the species by feeding on all main types of prey, including littoral benthos, zooplankton and small fish, the latter never being found in the stomach contents of whitefish or grayling. Whitefish dominated the pelagic niche by feeding mainly on zooplankton and being the only fish species caught abundantly in the pelagic zone. Grayling was in contrast rather strictly specialised in a littoral niche in all lake systems. Despite high niche segregation, the three species may, however, feed on common prey items (e.g., chironomid pupae in springtime) when they are superabundant (Robinson \& Wilson 1998; Amundsen et al. 2010).

Our findings illustrate a classic interactive segregation between sympatric salmonids (e.g., Nilsson 1965 Jonsson et al. 2008), which, according to competition theory (Gause 1934; Pianka 2000), is fundamental for ecologically similar species to prevent extinction of the weaker competitor. Here, the trophic niche of Arctic charr was confined to benthivory and piscivory, most probably due to an inferior ability to compete for pelagic food resources with the superior whitefish (e.g., Svärdson 1976). Whitefish also largely monopolised the consumption of the semi-benthic chydorid E. lamellatus commonly utilised by Arctic charr in some lakes (Adalsteinsson 1979; Amundsen et al. 2008). Whitefish is a generalist forager and commonly includes a variety of zoobenthos in its diet (Amundsen et al. 2004; Harrod et al. 2010), but rarely consumed large benthic invertebrates in the present study lakes. These prey groups were important food sources for Arctic charr and particularly for grayling. Hence, whitefish seemed to have a restricted trophic niche, likely resulting from competitive interactions with the other two fish species. Grayling usually forage on surface insects and benthic invertebrates along the shallow lake shores (Northcote 1995), but in sympatry with brown trout, they may shift foraging habitat to deeper areas (Haugen \& Rygg 1996). In our study lakes, there were no clear signs of competitive constraints on grayling as they appeared to utilise their principal littoral niche. A few grayling were caught in the pelagic and profundal habitats, but these individuals had littoral benthos in their stomachs and high $\delta^{13} \mathrm{C}$ values, indicating that they just briefly had left their principal littoral foraging habitat.
Our study clearly demonstrates that Arctic charr can naturally coexist with whitefish even in shallow lakes with relatively smaller contributions of profundal habitat offering refuge against competitive interactions between the species (cf. Svärdson 1976; Sandlund et al. 2010). However, a well-developed profundal zone may to some extent explain the higher density of Arctic in the deep Biggijavri than in the other two shallow lakes. The presence of grayling in the littoral zone apparently facilitates the stable coexistence of Arctic charr and whitefish in Biggijavri (Abrams \& Rueffler 2009; Amundsen et al. 2010), but is apparently important also in the two shallower lakes. In Vuolit Spielgajavri, grayling was the most abundant species and, by dominating the littoral niche, seemed to relegate whitefish from the littoral zone into the profundal and pelagic habitat to feed mainly on zooplankton. These competitive constraints on whitefish probably give Arctic charr better possibilities to exploit some littoral and pelagic resources commonly taken over by whitefish. Sandlund et al. (2010) also suggested that the existence of perch (Perca fluviatilis) in the littoral zone may restrict the niche use of whitefish and thereby facilitate survival of sympatric Arctic charr. The stable coexistence of Arctic charr and whitefish can also be facilitated by heavy whitefish exploitation or extensive stocking of Arctic charr (Gerdeaux et al. 2002; Museth et al. 2007), but no considerable fishery or any stocking is occurring in the present study lakes.

The largely congruent results of the habitat, stomach contents and stable isotope analyses, and of the present and the previous study from Biggijavri (Amundsen et al. 2010), suggest a temporally stable niche segregation between Arctic charr, whitefish and grayling. Although the present study is based on only one field sampling period with no information on seasonal variations in the trophic niches (cf. Amundsen et al. 2010), our stable isotope estimates from fish muscle samples provide a time-integrated, indirect measure of resource use covering the last few months before sampling (Fry 2006; Buchheister \& Latour 2010). The SIAR model generally succeeded in interpreting raw stable carbon and nitrogen isotope ratios into estimations of important diet contributions. Likewise, the larger individual variation in $\delta^{13} \mathrm{C}$ and $\delta^{15} \mathrm{~N}$ values indicated a wider trophic niche (i.e., higher dietary plasticity) for Arctic charr compared to sympatric whitefish and grayling, similar to what was indicated by the stomach content data. The high $\delta^{15} \mathrm{~N}$ values and the large contribution of fish in the stomach contents of Arctic charr also demonstrated a strong shift towards piscivory in the two shallow lakes. According to both SIAR and habitat data, whitefish relied strongly on pelagic and profundal resources in Vuolit Spielgajavri, likely due to interspecific interactions by abundant grayling in the littoral niche. 


\section{Eloranta et al.}

Despite the generally congruent results, there were, however, some mismatches between the SIAR and stomach content data, likely due to (i) missing food sources or (ii) other uncertainties incorporated in the SIAR, or simply due to (iii) the different temporal resolutions of the methods. For instance, the SIAR model could apparently not distinguish well between the contributions of profundal benthos and fish because of the similar $\delta^{15} \mathrm{~N}$ values of these food sources. Consequently, based on the SIAR estimates, Arctic charr predominantly fed on profundal benthos in Datkujavri, whereas the stomach contents indicated a nearly pure piscivorous diet. However, some piscivorous Arctic charr in Datkujavri may actually have consumed small whitefish, which have notably lower (i.e., more pelagic) $\delta^{13} \mathrm{C}$ values (ranging from -27.0 to $-28.7 \%$ in $93-$ to 150-mm-long whitefish) compared to the prey fish used in the SIAR model (i.e., small littoral minnows and burbots). The estimated contributions of profundal benthos and zooplankton in the grayling diet may result from foraging on terrestrial insects, which commonly have lower $\delta^{13} \mathrm{C}$ values than littoral aquatic insects (Bennet \& Hobson 2009). Furthermore, the stomach contents suggested that whitefish in Vuolit Spielgajavri and Datkujavri had fed mainly on zooplankton, whereas the SIAR estimates suggested a larger contribution of profundal prey. This difference might result from the fact that the $\delta^{13} \mathrm{C}$ and $\delta^{15} \mathrm{~N}$ values largely reflect the summertime diet of whitefish, which commonly consists of benthic prey and chironomid pupae (Kahilainen et al. 2004; Amundsen et al. 2010) and thus not reflect the most recent food utilisation dominated by zooplankton. Altogether, the resource partitioning observed from the habitat and prey utilisation of the three salmonid species was largely captured by the SIAR model.

Arctic charr is known as a generalist and opportunistic species with the potential to utilise all kinds of habitats and food sources in a lake (Amundsen et al. 2008; Eloranta et al. 2010). The dietary plasticity of Arctic charr is crucial for survival in high-latitude lakes with seasonally fluctuating food supplies (Johnson 1980), but it also has evolutionary consequences as in some lakes Arctic charr may occur as 1-4 sympatric morphs with distinct benthivorous, planktivorous and/or piscivorous niches (Klemetsen 2010). Arctic charr in our lakes showed no signs of polymorphism, but nevertheless, a high dietary plasticity was observed as they utilised mainly benthic food in the deep Biggijavri and shifted to a partially piscivorous niche in the shallower lakes. The potential for piscivory in Arctic charr is probably an important factor widening the trophic niche and thereby supporting the stable coexistence of Arctic charr and whitefish in subarctic lakes. In some large and deep lakes in northern Finland, large piscivorous Arctic charr mainly consume whitefish and thereby regulate the population size and niche use of this potential competitor (Kahilainen \& Lehtonen 2002). However, no remains of whitefish were found from the stomach contents of Arctic charr from our lakes. The presence of other small prey fish (i.e., minnows and burbots) presumably supported the piscivorous feeding of Arctic charr in these lakes, as also observed in some shallow Swedish lakes where Arctic charr prey extensively on nine-spined sticklebacks (Pungitius pungitius) (Karlsson \& Byström 2005). The low catches of small Arctic charr in Datkujavri could be attributed to cannibalism (Byström 2006) or burbot predation (Knudsen et al. 2010), although no cannibalism was observed and the burbot catch was low in all three study lakes.

In general, the classic competitive exclusion principle (Gause 1934; Hardin 1960) seems to apply to the interactions between Arctic charr and whitefish, as many native Arctic charr populations in northern Europe have become extinct or have severely declined after introduction or invasion of whitefish (Nilsson 1965; Nilsson \& Pejler 1973; Svärdson 1976). However, in our three study lakes, the two species naturally co-occur in substantial densities because of niche divergence. In large and deep lakes, Arctic charr may find a suitable niche in the deep profundal habitat (Sandlund et al. 2010) and/or by undergoing an ontogenetic dietary shift to piscivory (Kahilainen \& Lehtonen 2002). However, our study clearly demonstrates that Arctic charr does not necessarily need an extensive profundal zone as a refuge against deleterious interactions from whitefish. This is likely a consequence of the exceptional dietary plasticity of Arctic charr enabling adaptation to different trophic niches depending on the availability of habitat and food sources. In conclusion, the ability of Arctic charr to widen its trophic niche towards piscivory in the presence of suitable prey fish, and the presence of a third competing fish species like grayling in the littoral zone evidently facilitates the coexistence of Arctic charr with the commonly competitively superior whitefish.

\section{Acknowledgements}

We thank Laina Dalsbø, Cesilie Lien, Anne Kettunen, Kim Præbel and Grethe Robertsen for assistance in the field and laboratory work. Roger I. Jones, Kimmo Kahilainen, Juha Merilä, Jouni Taskinen and two anonymous reviewers are acknowledged for valuable comments and grammar corrections on the manuscript. The study was financed by the Norwegian Research Council (NFR 186320/V40; AS, RK and PAA) and the Jenny and Antti Wihuri Foundation (AE). 


\section{Coexistence of Arctic charr and whitefish}

\section{References}

Abrams, P.A. \& Rueffler, C. 2009. Coexistence and limiting similarity of consumer species competing for a linear array of resources. Ecology 90: 812-822.

Adalsteinsson, H. 1979. Size and food of Arctic char Salvelinus alpinus and stickleback Gasterosteus aculeatus in Lake Myvatn. Oikos 32: 228-231.

Amundsen, P.-A. 1994. Piscivory and cannibalism in Arctic charr. Journal of Fish Biology, 45(Supplement A): 181-190. Amundsen, P.-A., Gabler, H.-M. \& Staldvik, F.J. 1996. A new approach to graphical analysis of feeding strategy from stomach contents data -modification of the Costello (1990) method. Journal of Fish Biology 48: 607-614.

Amundsen, P.-A., Knudsen, R., Klemetsen, A. \& Kristoffersen, R. 2004. Resource competition and interactive segregation between sympatric whitefish morphs. Annales Zoologic Fennici 41: 301-307.

Amundsen, P.-A., Knudsen, R. \& Klemetsen, A. 2008. Seasonal and ontogenetic variations in resource use by two sympatric Arctic charr morphs. Environmental Biology of Fishes 83: 45-55.

Amundsen, P.-A., Knudsen, R. \& Bryhni, H.T. 2010. Niche use and resource partitioning of Arctic charr, European whitefish and grayling in a subarctic lake. Hydrobiologia 650:3-14.

Bennet, P.M. \& Hobson, K.A. 2009. Trophic structure of a boreal forest arthropod community revealed by stable isotop $\left(\delta^{13} \mathrm{C}, \delta^{15} \mathrm{~N}\right)$ analyses. Entomological Science 12: 17-24.

Buchheister, A. \& Latour, R.J. 2010. Turnover and fractionation of carbon and nitrogen stable isotopes in tissues of a migratory coastal predator, summer flounder (Paralichthys dentatus). Canadian Journal of Fisheries and Aquatic Sciences 67: 445-461.

Byström, P. 2006. Recruitment pulses induce cannibalistic giants in Arctic charr. Journal of Animal Ecology 75: 434-444.

Calenge, C. 2006. The package "adehabitat" for the R software: a tool for the analysis of space and habitat use by animals. Ecological Modelling 197: 516-519.

Corrigan, L.J., Winfield, I.J., Hoelzel, A.R. \& Lucas, M.C. 2011. Dietary plasticity in Arctic charr (Salvelinus alpinus) in response to long-term environmental change. Ecology of Freshwater Fish 20: 5-13.

Eloranta, A.P., Kahilainen, K.K. \& Jones, R.I. 2010. Seasonal and ontogenetic shifts in diet of Arctic charr Salvelinus alpinus in a subarctic lake. Journal of Fish Biology 77: 8097.

Fry, B. 2006. Stable isotope ecology. New York, NY: Springe Science + Business Media, LLC. xii +308 pp.

Gause, G.F. 1934. The struggle for existence. Baltimore, MD Williams \& Wilkins Co. 163 pp.

Gerdeaux, D., Bergeret, S., Fortin, J. \& Barronet, T. 2002. Diet and seasonal patterns of food composition of Coregonu lavaretus in Lake Annecy: comparison with diet of other species of the fish community. Archiv für Hydrobiologie 57: 199-207.

Graham, C.T. \& Harrod, C. 2009. Implications of climat change for the fishes of the British Isles. Journal of Fish Biology 74: 1143-1205.

Hardin, G. 1960. The competitive exclusion principle. Science 131: 292-297.
Harrod, C., Mallela, J. \& Kahilainen, K.K. 2010. Phenotypeenvironment correlations in a putative whitefish adaptive radiation. Journal of Animal Ecology 79: 1057-1068.

Haugen, T.O. \& Rygg, T.A. 1996. Food and habitat-segregation in sympatric grayling and brown trout. Journal of Fish Biology 49: 301-318.

Johnson, L. 1980. The Arctic charr, Salvelinus alpinus. In Balon, E.K., ed. Charrs: salmonid fishes of the genus Salvelinus. The Hauge, Netherlands: Dr W. Junk, pp. 15-98 Jonsson, B., Jonsson, N., Hindar, K., Northcote, T.G. \& Engen, S. 2008. Asymmetric competition drives lake use of coexisting salmonids. Oecologia 157: 553-560.

Kahilainen, K.K. \& Lehtonen, H. 2002. Brown trout (Salmo trutta L.) and Arctic charr (Salvelinus alpinus (L.)) as predators on three sympatric whitefish (Coregonus lavaretus (L.)) forms in the subarctic Lake Muddusjärvi. Ecology of Freshwater Fish 11: 158-167.

Kahilainen, K., Malinen, T., Tuomaala, A. \& Lehtonen, H. 2004. Diel and seasonal habitat and food segregation of three sympatric Coregonus lavaretus forms in a subarctic lake. Journal of Fish Biology 64: 418-434.

Karlsson, J. \& Byström, P. 2005. Littoral energy mobilization dominates energy supply for top consumers in subarctic lakes. Limnology and Oceanography 50: 538-543.

Kiljunen, M., Grey, J., Sinisalo, T., Harrod, C., Immonen, H. \& Jones, R.I. 2006. A revised model for lipid-normalizing $\delta^{13} \mathrm{C}$ values from aquatic organisms, with implications for isotope mixing models. Journal of Applied Ecology 43: 1213-1222 Klemetsen, A. 2010. The charr problem revisited: exceptional phenotypic plasticity promotes ecological speciation in postglacial lakes. Freshwater Reviews 3: 49-74.

Klemetsen, A., Amundsen, P.-A., Dempson, J.B., Jonsson, B. Jonsson, N., O'Conell, M.F.O. \& Mortensen, E. 2003. Atlantic salmon Salmo salar L., brown trout Salmo trutta L. and Arctic charr Salvelinus alpinus (L.): a review of aspects of their life histories. Ecology of Freshwater Fish 12: 1-59.

Knudsen, R., Amundsen, P.-A. \& Klemetsen, A. 2010. Arctic charr in sympatry with burbot: ecological and evolutionary consequences. Hydrobiologia 650: 43-54.

L'Abée-lund, J.H., Langeland, A. \& Sægrov, H. 1992. Piscivory by brown trout Salmo trutta L and Arctic char Salvelinus alpinus (L.) in Norwegian lakes. Journal of Fish Biology 41: 91-101

Langeland, A., L’Abée-lund, J.H., Jonsson, B. \& Jonsson, N. 1991. Resource partitioning and niche shift in Arctic charr Salvelinus alpinus and brown trout Salmo trutta. Journal of Animal Ecology 60: 895-912.

Layman, C.A., Quattrochi, J.P., Peyer, C.M. \& Allgeier, J.E. 2007. Niche width collapse in a resilient top predator following ecosystem fragmentation. Ecology Letters 10: 937-944.

Lehtonen, H. 1996. Potential effects of global warming on northern European freshwater fish and fisheries. Fisheries Management and Ecology 3: 59-71.

Levins, R. 1968. Evolution in changing environments: some theoretical explorations. Princeton, NJ: Princeton University Press. $132 \mathrm{pp}$.

Maitland, P.S. 1995. World status and conservation of the Arctic charr Salvelinus alpinus (L.). Nordic Journal of Freshwater Research 71: 113-127. 


\section{Eloranta et al.}

McCutchan, J.H., Lewis, W.M., Kendal, C. \& McGrath, C.C. 2003. Variation in trophic shift for stable isotope ratios of carbon, nitrogen, and sulfur. Oikos 102: 378-390.

Museth, J., Sandlund, O.T. \& Borgstrøm, R. 2007. Coexistence between introduced whitefish (Coregonus lavaretus) and native Arctic charr (Salvelinus alpinus) depends on heavy whitefish exploitation. Advances in Limnology 60: 343-350.

Nilsson, N.-A. 1965. Food segregation between salmonid species in North Sweden. Report of the Institute of Freshwater Research, Drottningholm 2: 58-78.

Nilsson, N.-A. 1967. Interactive segregation between fish species. In: Gerking, S.D., ed. The biological basis of freshwater fish production. Oxford, UK: Blackwell Scientific Publications, pp. 295-313.

Nilsson, N.-A. \& Pejler, B. 1973. On the relation between fish fauna and zooplankton composition in north Swedish lakes. Report of the Institute of Freshwater Research, Drottningholm 53: 51-77.

Northcote, T.G. 1995. Comparative biology and management of Arctic and European grayling (Salmonidae, Thymallus). Reviews in Fish Biology and Fisheries 5: 141-194.

Parnell, A.C., Inger, R., Bearhop, S. \& Jackson, A.L. 2010 Source partitioning using stable isotopes: coping with too much variation. PLoS ONE 5: e9672.

Pianka, E.R. 2000. Evolutionary ecology, 6th edn. San Francisco, CA: Benjamin-Cummings. 512 pp.

Post, D.M. 2002. Using stable isotopes to estimate trophic position: models, methods, and assumptions. Ecology 83: 703-718.
R Development Core Team. 2009. R: a language and environment for statistical computing. Vienna, Austria: R Foundation for Statistical Computing.

Robinson, B.W. \& Wilson, D.S. 1998. Optimal foraging, specialization, and a solution to Liem's paradox. The American Naturalist 151: 223-235.

Sandlund, O.T., Museth, J., Næsje, T.F., Rognerud, S. Saksgård, R., Hesthagen, T. \& Borgstrøm, R. 2010. Habitat use and diet of sympatric Arctic charr (Salvelinus alpinus) and whitefish (Coregonus lavaretus) in five lakes in southern Norway: not only interspecific population dominance? Hydrobiologia $650: 27-41$.

Schoener, T.W. 1970. Nonsynchronous spatial overlap of lizards in patchy habitats. Ecology, 51: 408-418.

Svärdson, G. 1976. Interspecific population dominance in fish communities of Scandinavian lakes. Report of the Institute of Freshwater Research, Drottningholm 55: 144-171.

Vander Zanden, M.J. \& Rasmussen, J.B. 1999. Primary consumer $\delta^{13} \mathrm{C}$ and $\delta^{15} \mathrm{~N}$ and the trophic position of aquatic consumers. Ecology 80: 1395-1404.

Wallace, R.K. 1981. An assessment of diet-overlap indexes. Transactions of the American Fisheries Society 110: 72-76.

Walther, G.-R., Post, E., Convey, P., Menzel, A., Parmesan, C., Beebee, T.J.C., Fromentin, J.-M., Hoegh-Guldberg, O. \& Bairlein, F. 2002. Ecological responses to recent climate change. Nature 416: 389-395.

Winfield, I.J., Fletcher, J.M. \& James, J.B. 2010. An overview of fish species introductions to the English Lake District, UK, an area of outstanding conservation and fisheries importance. Journal of Applied Ichthyology 26: 60-65. 


\section{NICHE SEGREGATION OF COEXISTING ARCTIC CHARR \\ (Salvelinus alpinus) AND BROWN TROUT (Salmo trutta) CONSTRAINS FOOD WEB COUPLING IN SUBARCTIC LAKES}

Antti P. Eloranta, Rune Knudsen \& Per-Arne Amundsen 2013

Freshwater Biology 58: 207-221.

Reprinted with kind permission of John Wiley and Sons $($ ) 


\title{
Freshwater Biology
}

\section{Niche segregation of coexisting Arctic charr (Salvelinus alpinus) and brown trout (Salmo trutta) constrains food web coupling in subarctic lakes}

\author{
ANTTI P. ELORANTA*, RUNE KNUDSEN ${ }^{\dagger}$ AND PER-ARNE AMUNDSEN ${ }^{\dagger}$ \\ "Department of Biological and Environmental Sciences, University of Jyväskylä, Jyväskylä, Finland \\ ${ }^{\dagger}$ Department of Arctic and Marine Biology, Faculty of Biosciences, Fisheries and Economics, University of Tromsø, Tromsø, Norway
}

\section{SUMMARY}

1. Generalist fish species are recognised as important couplers of benthic and pelagic food-web compartments in lakes. However, interspecific niche segregation and individual specialisation may limit the potential for generalistic feeding behaviour.

2. We studied summer habitat use, stomach contents and stable isotopic compositions of the generalist feeder Arctic charr coexisting with its common resource competitor brown trout in five subarctic lakes in northern Norway to reveal population-level and individual-level niche plasticity.

3. Charr and trout showed partial niche segregation in all five lakes. Charr used all habitat types and a wide variety of invertebrate prey including zooplankton, whereas trout fed mainly on insects in the littoral zone. Hence, charr showed a higher potential to promote habitat and food-web coupling compared to littoral-dwelling trout.

4. The level of niche segregation between charr and trout and between pelagic-caught and littoralcaught charr depended on the prevailing patterns of interspecific and intraspecific resource competition. The two fish species had partially overlapping trophic niches in one lake where charr numerically dominated the fish community, whereas the most segregated niches occurred in lakes where trout were more abundant.

5. In general, pelagic-caught charr had substantially narrower dietary and isotopic niches and relied less on littoral carbon sources compared to littoral-caught conspecifics that included generalist as well as specialised benthivorous and planktivorous individuals. Despite the partially specialised planktivorous niche and thus reduced potential of pelagic-dwelling charr to promote benthic-pelagic coupling, the isotopic compositions of both charr subpopulations suggested a significant reliance on both littoral and pelagic carbon sources in all five study lakes.

6. Our study demonstrates that both interspecific niche segregation between and individual trophic specialisation within generalist fish species can constrain food-web coupling and alter energy mobilisation to top consumers in subarctic lakes. Nevertheless, pelagic and littoral habitats and food-web compartments may still be highly integrated due to the potentially plastic foraging behaviour of top consumers.

Keywords: benthic-pelagic coupling, energy mobilisation, individual specialisation, resource partitioning, stable isotopes

Correspondence: Antti P. Eloranta, Department of Biological and Environmental Sciences, University of Jyväskylä, PO Box 35, FIN-40014 Jyväskylä, Finland.

E-mail: antti.eloranta@jyu.fi 


\section{Introduction}

During recent decades, attention has been directed to the role of fish top consumers in relation to benthic-pelagic coupling (Schindler \& Scheuerell, 2002; Vadeboncoeur, Vander Zanden \& Lodge, 2002), food-web dynamics (Post, Conners \& Goldberg, 2000) and trophic cascades (Jeppesen et al., 2003; Vadeboncoeur et al., 2005) in lake ecosystems. Generalist fish are particularly important in promoting habitat and food-web coupling in lakes due to their high mobility and flexible feeding on both benthic and pelagic prey (Polis, Anderson \& Holt, 1997; Vander Zanden \& Vadeboncoeur, 2002; Vadeboncoeur et al., 2005). However, the ability of generalist fish to switch between benthic and pelagic trophic niches may depend on interspecific and intraspecific competition between fish species and among individuals (Quevedo, Svanbäck \& Eklöv, 2009; Vanni et al., 2009). Interspecific competition is generally expected to restrict niche use of sympatric species, whereas strong intraspecific competition may induce individual specialisation towards various resources and thus lead to wider niche use at the population level (e.g. Amundsen, 1995; Bolnick et al., 2003, 2010; Svanbäck \& Persson, 2004; Araújo, Bolnick \& Layman, 2011). Consequently, niche specialisation at the population and individual levels resulting from strong interspecific and intraspecific resource competition, respectively, may significantly limit the coupling between benthic and pelagic food-web compartments by generalist fish species (Quevedo et al., 2009). Because of the possible role of top consumers as important regulators of food-web dynamics and stability (Post et al., 2000; McCann, Rasmussen \& Umbanhowar, 2005; Rooney et al., 2006), generalist fish should be considered as heterogeneous rather than homogeneous sets of individuals, potentially with both specialised and generalist trophic niches (Bolnick et al., 2003, 2011; Araújo et al., 2011). Nevertheless, relatively few trophic studies of generalist fish species have focussed on niche variation and segregation at both the population and individual levels.

The role of generalist fish in habitat and food-web coupling may be particularly pronounced in oligotrophic high-latitude lakes with relatively simple communities (Christoffersen et al., 2008). In these lakes, Arctic charr (Salvelinus alpinus L., hereafter charr) may act as a topdown controller and integrator of pelagic and littoral food-web compartments due to its exceptional phenotypic plasticity (Klemetsen et al., 2003a; Klemetsen, 2010). However, the potentially wide trophic niche of charr is often restricted because of interspecific resource competition with sympatric fish species such as European whitefish
(Coregonus lavaretus L.) (Amundsen, Knudsen \& Bryhni, 2010; Sandlund et al., 2010; Eloranta et al., 2011), burbot (Lota lota L.) (Knudsen, Amundsen \& Klemetsen, 2010a) and, most commonly, brown trout (Salmo trutta L., hereafter trout; Nilsson, 1963; Langeland et al., 1991; Amundsen \& Knudsen, 2009). Competition between charr and trout has been widely studied (e.g. Nilsson, 1963; Svärdson, 1976; Langeland et al., 1991). When charr and trout are the only fish species present in the lake, they are both often observed to feed on relatively large-sized benthic prey such as insect larvae, molluscs and semibenthic crustaceans in the littoral zone (e.g. Nilsson, 1963, 1967). When the two fish species coexist in the same lake, trout, being a more aggressive and inflexible territorial feeder (Jansen et al., 2002), typically relegate charr from the littoral to the inferior pelagic or profundal trophic niche (Nilsson, 1963, 1967; Langeland et al., 1991). However, previous studies on charr and trout interactions have focussed on niche segregation at the population level and have not documented individual differences in niche use. Individual specialisation within generalist fish species may, however, strongly affect population and community dynamics and is also commonly considered as a leading force in the evolution of sympatric morphs and species (Araújo et al., 2011; Bolnick et al., 2011). Striking examples of the possible evolutionary outcome of individual niche specialisation have been observed within polymorphic charr populations where sympatric morphs can differ in habitat use, diet, morphology, parasite fauna and in spawning times and sites (reviewed by Klemetsen, 2010). However, strong intraspecific resource competition has been observed to induce individual niche specialisation even within monomorphic charr populations (Amundsen, 1995; Eloranta, Kahilainen \& Jones, 2010). The contrasting physical and biological characteristics of pelagic and littoral habitats, including differences in the size, abundance and diversity of available prey organisms (Schindler \& Scheuerell, 2002; Vadeboncoeur et al., 2002), provide substantial potential in generalist fish species for individual specialisation to pelagic or benthic trophic niches (e.g. Bolnick et al., 2003; Quevedo et al., 2009). Pelagic fish are often specialised to feed on small-bodied zooplankton and thus show little among-individual variation in diet, whereas littoral fish generally show a more plastic foraging behaviour, but may also consist of individuals with specialised benthivorous, planktivorous or piscivorous diets. Consequently, intrapopulation niche segregation between pelagic- and littoral-dwelling individuals may limit habitat and food-web coupling in lake ecosystems (Quevedo et al., 2009).

(c) 2012 Blackwell Publishing Ltd, Freshwater Biology, 58, 207-221 
Previous studies of trophic niche segregation between sympatric charr and trout have almost all used traditional habitat and stomach content analyses (SCA). However, these methods only give a snapshot of the recent niche and thus may lead to incorrect interpretation of the longterm trophic niche. Stable carbon and nitrogen isotope analysis (SIA) provides an alternative and cost-effective tool to study the predominant long-term niche use of fish populations and individuals as well as whole-lake foodweb structure (Araújo et al., 2007; Boecklen et al., 2011; Layman et al., 2012). The use of stable carbon and nitrogen isotope ratios (expressed as $\delta^{13} \mathrm{C}$ and $\delta^{15} \mathrm{~N}$, respectively) in studies of fish diets and lake food-web structure is based on the distinct $\delta^{13} \mathrm{C}$ values of pelagic and littoral primary producers and on the trophic enrichment of $\delta^{15} \mathrm{~N}$ by around 3-4\% per trophic level (Post, 2002). The $\delta^{13} \mathrm{C}$ and $\delta^{15} \mathrm{~N}$ values from fish muscle tissue typically reflect the diet assimilated over a few months (Hesslein, Hallard \& Ramlal, 1993; Buchheister \& Latour, 2010). Hence, isotopic studies of fish trophic ecology are not subject to the same potential sampling errors as SCA, such as temporal changes in availability, patchy distribution and different digestion times of prey items (Araújo et al., 2007; Boecklen et al., 2011). Moreover, the range in $\delta^{13} \mathrm{C}$ and $\delta^{15} \mathrm{~N}$ values, which is commonly referred to as the isotopic niche (see Layman et al., 2012 and references therein), can be used as a convenient measure of the trophic niche width of a population and the individual specialisation within (Bearhop et al., 2004; Araújo et al., 2007; Jackson et al., 2011). The long-term reliance of fish populations and individuals on littoral versus pelagic carbon can be studied using two-source isotopic mixing models (Layman et al., 2012 and references therein). By comparing the results from SCA and SIA, it is also possible to evaluate the temporal stability of individual niche plasticity or specialisation

In the context of the potentially wide-ranging impacts of generalist fish species on food-web dynamics in highlatitude lakes, we studied population-level and individual-level trophic niche plasticity of charr coexisting with trout in five subarctic lakes in northern Norway. We contrasted habitat use, stomach contents and stable carbon and nitrogen isotopes from muscle tissue to reveal possible niche segregation between the charr and trout populations and between charr caught in pelagic and littoral zones. We hypothesised that (i) coexisting charr and trout would show significant niche segregation reflected by their habitat use, stomach contents and stable isotopic compositions. We further hypothesised that (ii) charr at the population level would have a wider trophic niche than trout. Within the charr populations, we

(c) 2012 Blackwell Publishing Ltd, Freshwater Biology, 58, 207-221 hypothesised (iii) a distinct niche segregation between pelagic-caught charr (specialised on zooplankton) and littoral-caught charr (having a wider and more benthic trophic niche). Such niche partitioning between pelagic and littoral charr can be expected to limit the connectivity between pelagic and benthic food-web compartments.

\section{Methods}

Study site

The five study lakes, Lille Rostavatn $\left(69^{\circ} 00^{\prime} \mathrm{N}, 19^{\circ} 35^{\prime} \mathrm{E}\right)$, Fjellfrøsvatn $\left(69^{\circ} 05^{\prime} \mathrm{N}, 19^{\circ} 20^{\prime} \mathrm{E}\right)$, Takvatn $\left(69^{\circ} 07^{\prime} \mathrm{N}, 19^{\circ} 05^{\prime} \mathrm{E}\right)$, Sagelvvatn $\left(69^{\circ} 11^{\prime} \mathrm{N}, 1^{\circ} 06^{\prime} \mathrm{E}\right)$ and Josefvatn $\left(69^{\circ} 15^{\prime} \mathrm{N}\right.$, $\left.19^{\circ} 09^{\prime} \mathrm{E}\right)$, are all oligotrophic, dimictic and relatively deep lakes situated near Troms county in subarctic northern Norway (see Table S1 in Supporting Information). The lakes are ice-covered for 6-7 months from November/December to May/June. Lille Rostavatn, Fjellfrøsvatn and Takvatn discharge to separate tributaries of the Målselv river system. The lakes are surrounded by mountains, birch (Betula pubescens Ehrh.) and scattered pine (Pinus sylvestris L.) forests and patches of farmland. Sagelvvatn and Josefvatn are located in separate small watercourses and have larger fields and settlements in their catchments. Sagelvvatn and Josefvatn have slightly more turbid water and more macrophyte vegetation than the other three study lakes, whose littoral zones are rocky and sandy.

Charr and trout are the only fish species present in Fjellfrøsvatn, whereas three-spined sticklebacks (Gasterosteus aculeatus L.) are also present in Takvatn, Sagelvvatn and Josefvatn. The more diverse fish community in Lille Rostavatn is dominated by charr, trout and grayling (Thymallus thymallus L.), while burbot (Lota lota L.), Atlantic salmon parr (Salmo salar L.) and Eurasian minnow (Phoxinus phoxinus Rafinesque 1820) are present at relatively low densities (making up $<4 \%$ of the total catch with multimesh gill nets). In Fjellfrøsvatn, a profundal charr morph coexists with the ordinary littoral charr (see Amundsen, Knudsen \& Klemetsen, 2008 for further details). However, all identified profundal charr morph individuals were excluded from the present study, and in the other lakes, charr exist as monomorphic populations.

\section{Sample collection}

All samples were collected from the lakes in August 2010. Fish were sampled with multimesh survey gill nets (eight randomly distributed $5-\mathrm{m}$ panels of $10,12.5,15,18.5,22$, 26, 35 and $45 \mathrm{~mm}$ knot-to-knot mesh sizes) set overnight 
210 A. P. Eloranta et al.

for 11-13 hours (for 3-4 nights in each lake) on the bed of the littoral and profundal zones (1.5-m-high and 40-mlong benthic gill nets; depths $0-10$ and $>20 \mathrm{~m}$, respectively) and in the uppermost pelagic zone (6-m-high floating gill nets; set to the surface above $>20 \mathrm{~m}$ depth). Catch per unit effort (CPUE; number of fish $100 \mathrm{~m}^{-2}$ survey gill net night ${ }^{-1}$ ) was estimated for each fish species caught on each sampling occasion from the littoral, profundal and pelagic habitats. For SCA and SIA, some additional fish were sampled using 30-m-long and 1.5-mdeep single mesh-sized $(6,8,26,29,30,35,36,45$ and $62 \mathrm{~mm}$ ) benthic gill nets. Gill nets should optimally be conducted with 24-hour series at 2- to 4-h examination intervals to avoid digestion and regurgitation of stomach contents or skew of diet data to night-time situation (see Bowen, 1996). However, we are confident that our stomach content data reflect the typical short-term diet of the fish because the relatively low water temperature $\left(5.0-15.4{ }^{\circ} \mathrm{C}\right)$ in all the lakes and habitats reduces digestion rate (see the numbers of empty stomachs in Table S2 in Supporting Information), while constant summer-time daylight probably reduces daily habitat and dietary shifts (see also Amundsen \& Klemetsen, 1986, 1988).

Zooplankton were collected for SIA by several vertical hauls with a $100-\mu \mathrm{m}$ plankton net from depths of $25-30 \mathrm{~m}$ to the surface until a sufficient material was obtained. Qualitative samples of littoral (depth 0-9 m) and profundal (depth 25-40 m) zoobenthos were collected using a kick net ( $500 \mu \mathrm{m}$ mesh) along the lakeshore and a benthic sledge with $500 \mu \mathrm{m}$ mesh in deeper areas. Both zooplankton and zoobenthos were sorted to genus level and held in cool tap water to allow gut evacuation. For molluscs, only the soft body tissue was prepared for SIA.

Each fish was identified, measured (fork length, $\mathrm{mm}$ ) and weighed (g). For SIA, a small block of dorsal muscle posterior to the dorsal fin was dissected from random subsamples of fish and stored at $-20{ }^{\circ} \mathrm{C}$ until being freezedried for $48 \mathrm{~h}$ and ground to a fine powder. The stomachs were removed and preserved in $96 \%$ ethanol for later analysis. The stomachs were opened and the total fullness was visually determined on a percentage scale ranging from empty $(0 \%)$ to full $(100 \%)$. The prey items were identified to species, genus or family level, and their contributions to total stomach contents were estimated according to Amundsen, Gabler \& Staldvik (1996). The prey taxa were grouped as (I) cladoceran zooplankton (Bosmina sp., Daphnia sp. and Holopedium sp.), (II) predatory cladoceran zooplankton (Bythotrephes sp. and Polyphemus sp.), (III) copepod zooplankton (Cyclopoida, Calanoida and Acanthocyclops sp.), (IV) molluscs (Lymnaea sp., Planorbidae and Valvatidae snails and Pisidium sp. mussels), (V) Gammarus lacustris Sars 1863 amphipods, (VI) chironomid larvae, (VII) trichoptera larvae, (VIII) other benthos (mostly Ephemeroptera, Dytiscidae, Megaloptera and semi-benthic Eurycercus sp. chydorid), (IX) pleuston (chironomid pupae, trichoptera pupae and adult stages of various aquatic and terrestrial insects) and (X) fish (three-spined sticklebacks and charr).

Schoener's (1970) similarity index $(\alpha)$ was used to study habitat and dietary overlap between all charr and trout and the dietary overlap between pelagic-caught and littoral-caught charr. An overlap that exceeds $60 \%$ is commonly considered high (Wallace, 1981). Levins (1968) index $(B)$ was calculated to estimate the trophic niche width for all charr and trout and separately for pelagiccaught and littoral-caught charr. In addition, a proportional similarity $\left(P S_{i}\right)$ index (Bolnick et al., 2002) was calculated to measure individual dietary specialisation within all charr and trout and within the pelagic and littoral charr subpopulations. The index compares each individual's diet to the overall diet of the population and approaches 1 when the individual has a similar diet to that of the population. The overall prevalence of individual specialisation was further calculated as the inverse of the average individual $P S_{i}$ values (i.e. $1-I S$, where $I S$ = average of individual $P S_{i}$ values; cf. Quevedo et al., 2009). Equations for the habitat and diet metrics are given in Table S3 in Supporting Information.

\section{Stable isotope analyses}

Stable carbon and nitrogen isotope analysis of samples from fish muscle and from the potential food sources were conducted using a FlashEA 1112 elemental analyser (Thermo Fisher Scientific Corporation, Waltham, MA, U.S.A.) coupled to a Thermo Finnigan DELTA ${ }^{\text {plus }}$ Advantage mass spectrometer at the University of Jyväskylä, Finland. From each sample, $0.500-0.600 \mathrm{mg}$ of freezedried and homogenised powder was weighed into tin capsules prior to analysis. Stable carbon and nitrogen isotope ratios are expressed as delta values $\left(\delta^{13} \mathrm{C}\right.$ and $\delta^{15} \mathrm{~N}$, respectively) relative to the international standards for carbon (Vienna PeeDee Belemnite) and nitrogen (atmospheric nitrogen). Pike (Esox lucius L.) white muscle tissue with known isotopic composition was used as an internal working standard and inserted in each run after every five samples. Standard deviation of the internal standard was $<0.16 \%$ for $\delta^{13} \mathrm{C}$ and $0.12 \%$ for $\delta^{15} \mathrm{~N}$ in each run. Muscle $\delta^{13} \mathrm{C}$ values were not corrected for lipids because their $\mathrm{C}: \mathrm{N}$ ratios (average $=3.2-3.3$, maximum $=3.7-3.9)$ indicated low lipid content for both fish species (Post et al., 2007).

(c) 2012 Blackwell Publishing Ltd, Freshwater Biology, 58, 207-221 
The SIAR (Stable Isotope Analysis in R, version 4.1.3; Parnell et al., 2010) package was used to estimate the longterm reliance on littoral versus pelagic carbon for all charr and trout and separately for the pelagic-caught and littoral-caught charr. The SIAR isotope mixing model uses a Bayesian approach to estimate dietary contributions and to consider uncertainties related to isotopic variation in the consumer and in the food sources as well as in the trophic fractionation factors (Parnell et al., 2010). The commonly used trophic fractionation factors of $0.4 \pm 1.3 \%$ for $\delta^{13} \mathrm{C}$ and $3.4 \pm 1.0 \%$ for $\delta^{15} \mathrm{~N}$ were used (Post, 2002). Concentrations of carbon and nitrogen were also incorporated into the SIAR model despite only minor differences between the food sources (total range 47-53\% for carbon and $7-13 \%$ for nitrogen). For SIAR, the pelagic baseline was calculated as the mean $\pm \mathrm{SD} \delta^{13} \mathrm{C}$ and $\delta^{15} \mathrm{~N}$ values of zooplankton, whereas the littoral baseline was calculated from the isotopic values of snails and G. lacustris collected from the littoral zone.

The SIBER (Stable Isotope Bayesian Ellipses in $\mathrm{R}$; Jackson et al., 2011) method was used in the SIAR package (version 4.1.3) to study isotopic niche widths (measured as the $S E A_{B}$ standard ellipse areas in $\delta^{13} \mathrm{C}-\delta^{15} \mathrm{~N}$ space) of the whole charr and trout populations as well as for the pelagic-caught and littoral-caught charr. Earlier metrics for isotopic niche width (e.g. total convex hull area; cf. Layman et al., 2007) are sensitive to differences in samples sizes, whereas $S E A_{B}$ ellipses are reformulated in a Bayesian approach to incorporate this and other uncertainties related to sampling (Jackson et al., 2011). Despite variable and relatively small sample sizes in some comparisons, the isotopic niche areas are thus assumed to reflect the general long-term niche widths and the level of individual specialisation within the studied charr and trout populations and charr subpopulations.

\section{Statistical analyses}

Mann-Whitney $U$-tests were used to test within-lake differences in fork length, $\delta^{13} \mathrm{C}$ and $\delta^{15} \mathrm{~N}$ values of all charr and trout and of pelagic-caught and littoral-caught charr. Mann-Whitney comparisons were made for $P S_{i}$ values between all charr and trout and between charr subpopulations. However, parametric $t$-tests were used when normality and homoscedasticity assumptions were met. The results of statistical comparisons are given in Table S4 in Supporting Information. A significance level of $P=0.05$ was used in all analyses. Statistical analyses were performed using PASW Statistics 18 for Windows (SPSS Inc., Chicago, IL, U.S.A), and the SIAR and SIBER packages were run in R 2.14.2. (R Development Core Team, 2012).

다 2012 Blackwell Publishing Ltd, Freshwater Biology, 58, 207-221

\section{Results}

A total of 751 charr and 444 trout were caught, of which 656 charr and 406 trout were caught with the multimesh gill nets. From the total gillnet catches, 533 charr and 366 trout were randomly chosen for SCA, while 572 charr and 360 trout were chosen for SIA. Of all charr, a total of 151 pelagic-caught and 203 littoral-caught charr were chosen for SCA, whereas 154 pelagic and 227 littoral charr were chosen for SIA. More details of gill net catches and sample sizes in SCA and SIA are given in Table S2.

The fork length of charr and trout caught with the multimesh gill nets ranged between $81-443 \mathrm{~mm}$ and $85-634 \mathrm{~mm}$, respectively. The two species did not differ significantly in fork length except in Sagelvvatn where trout were significantly larger (Tables S1 and S4). The pelagic-caught charr were significantly larger than littoralcaught charr in Fjellfrøsvatn, Takvatn and Sagelvvatn (Tables S1 and S4).

Interspecific niche segregation between charr and trout

In each study lake, charr were caught from all habitat types, whereas trout were almost exclusively caught from the littoral zone (Fig. 1). Based on Wallace's (1981) similarity index threshold of $60 \%$, the two fish species showed substantial habitat segregation in Lille Rostavatn, Takvatn and Josefvatn, but largely coexisted in the littoral zone in Fjellfrøsvatn and Sagelvvatn. Despite partial habitat overlap, the two species showed clear differences in stomach contents (Fig. 2a; see Table S5 in Supporting Information for detailed SCA data). Charr had in general a more diverse diet than trout (Table 1) and were mainly feeding on non-predatory cladoceran zooplankton and pleuston (Fig. 2a). In Sagelvvatn, charr were heavily specialised on zooplankton and thus showed a narrower dietary niche than trout. Trout were generally feeding more on pleuston, littoral zoobenthos and fish (mostly 23to 65 -mm three-spined sticklebacks and a few 80 - to 192$\mathrm{mm}$ charr) than charr. Charr showed a significantly higher degree of individual dietary specialisation than trout in Josefvatn, whereas there were no significant differences between the two species in Lille Rostavatn, Fjellfrøsvatn and Takvatn (Tables 1 and S4). In contrast, the largely planktivorous charr in Sagelvvatn showed a significantly lower level of individual dietary specialisation than trout.

Zooplankton and littoral zoobenthos had clearly separate $\delta^{13} \mathrm{C}$ values in all five study lakes (Fig. 3a), enabling the differentiation between primarily planktivorous and primarily benthivorous fish. In all the lakes, charr had 
212 A. P. Eloranta et al.

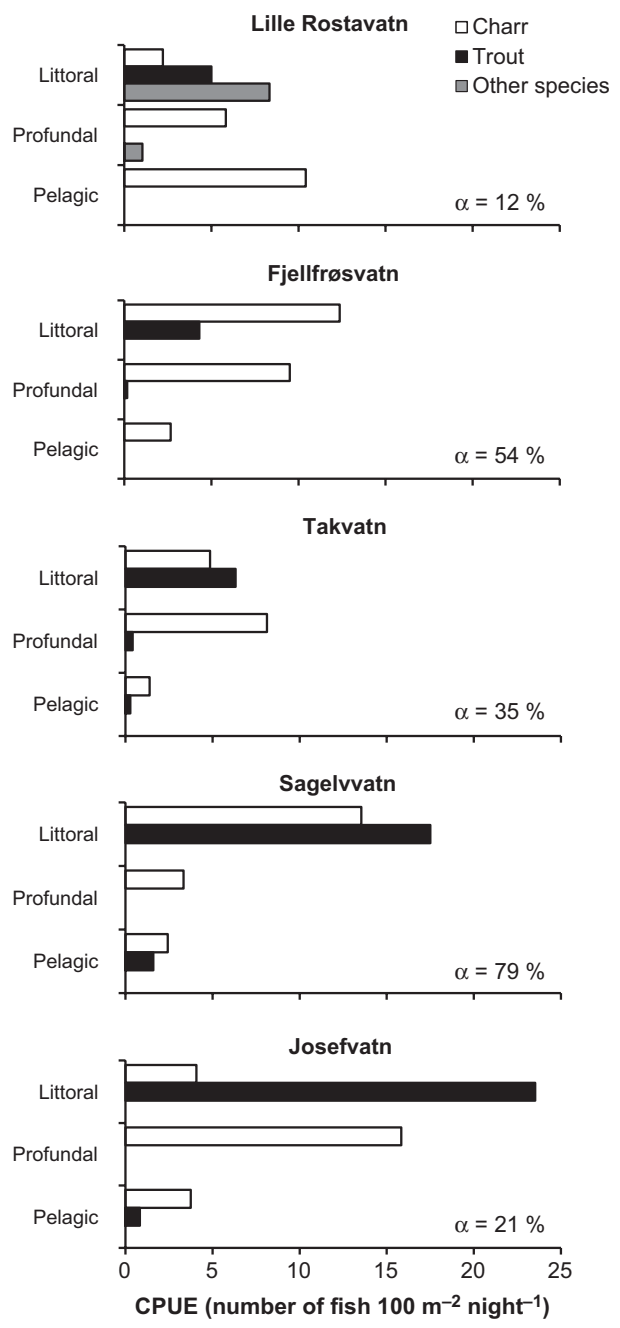

Fig. 1 Catch per unit effort (CPUE) of charr, trout and other fish species caught using multimesh gill nets from the littoral, profundal and pelagic habitats in the five study lakes. Schoener's habitat overlap indices $(\alpha)$ are shown in the figures.

significantly lower (i.e. more pelagic) muscle $\delta^{13} \mathrm{C}$ values than trout (Fig. 3a, Table S4). Charr also had significantly lower $\delta^{15} \mathrm{~N}$ values in Lille Rostavatn and Takvatn, but significantly higher $\delta^{15} \mathrm{~N}$ in Sagelvvatn and Josefvatn compared to trout. Correspondingly, the results from the
SIAR isotopic mixing model (Fig. 4) indicate a higher reliance of trout on littoral carbon sources compared to charr (range in 95\% Bayesian credibility intervals: 58-100 and $30-65 \%$, respectively). The isotopic niches of the two fish species were clearly distinct except in Fjellfrøsvatn and Takvatn (Fig. 3b). Charr showed a generally wider isotopic niche than trout except in Lille Rostavatn and Sagelvvatn (Table 1). Both species had relatively narrow isotopic niches in Lille Rostavatn, where they coexisted with four other fish species.

Intraspecific niche segregation between pelagic-caught and littoral-caught charr

The pelagic-caught charr generally showed narrower dietary and isotopic niches and a lower tendency for individual specialisation than their littoral-caught conspecifics (Figs $2 \mathrm{~b}$ and 3c, Tables 1 and S4). Both charr subpopulations fed on zooplankton and pleuston, but, based on the $60 \%$ threshold, dietary overlap was only substantial in Takvatn and Sagelvvatn (Fig. 2b). The littoral-caught charr generally relied more on littoral carbon sources than the pelagic-caught charr, as demonstrated by the higher $\delta^{13} \mathrm{C}$ values (Table S4) and SIAR estimates (Fig. 4). However, both pelagic and littoral charr relied substantially on littoral and pelagic carbon sources in all five study lakes and showed no significant differences in $\delta^{13} \mathrm{C}$ values in Takvatn and Josefvatn or in SIAR estimates in Sagelvvatn.

\section{Discussion}

Our study demonstrates that interspecific and intraspecific niche partitioning may alter the energy mobilisation to, and food-web coupling by, generalist fish top consumers in subarctic lakes. Our data suggest that trout may substantially restrict summer-time habitat use and plastic foraging behaviour of charr by dominating in the littoral niche. Correspondingly, the specialised planktivorous niche of pelagic-dwelling charr may substantially reduce the coupling between pelagic and benthic food-web compartments. However, due to their general niche plasticity, charr have greater potential to increase foodweb coupling in subarctic lakes than the largely littoraldwelling, benthivorous trout.

\section{Interspecific niche segregation between charr and trout}

Previous SIA studies have shown that the fish top consumers in high-latitude lakes generally rely more on littoral than on pelagic energy sources (e.g. Hecky \& Hesslein, 1995; Siers-

(C) 2012 Blackwell Publishing Ltd, Freshwater Biology, 58, 207-221 

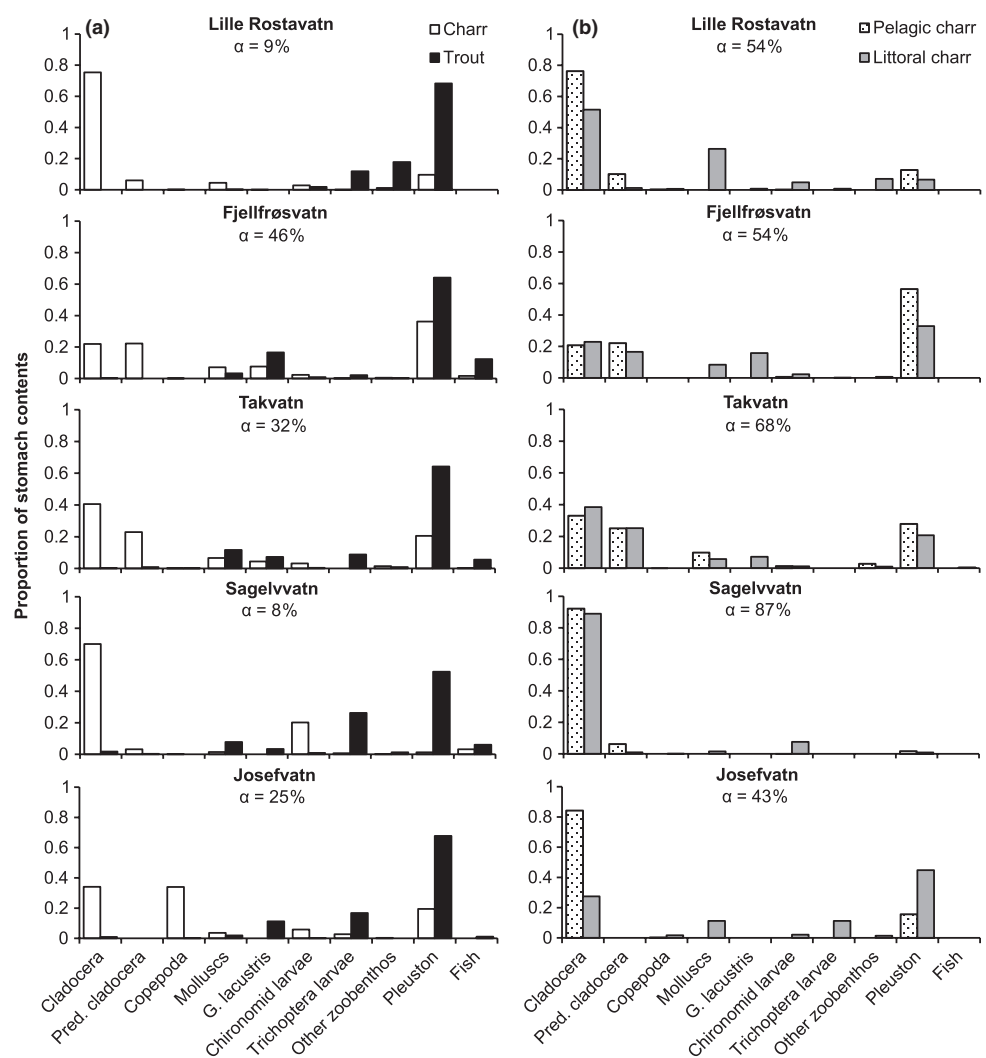

Fig. 2 Proportion of different prey groups in the stomach contents of (a) all charr and trout and (b) of pelagic-caught and littoral-caught charr. Schoener's diet similarity indices $(\alpha)$ are shown in the figures, while the estimated metrics for dietary niche width (Levins $B$ ) and individual specialisation $(1-I S)$ are given in Table 1.

zen, McDonald \& Jensen, 2003; Karlsson \& Byström, 2005; Eloranta et al.,2010). The dominance of littoral production in high-latitude lakes is commonly regarded as a consequence of oligotrophic and clear water limiting the production of pelagic phytoplankton, but simultaneously enhancing the growth of photosynthetic algae on the lake bottom (Hecky \& Hesslein, 1995; Vadeboncoeur et al., 2003). The benthic primary production supports the energy supply to zoobenthos and ultimately to benthivorous fish (Vander Zanden \& Vadeboncoeur, 2002; Vander Zanden, Vadeboncoeur \& Chandra, 2011). However, our study shows that a generalist fish (here charr) may switch from the littoral niche to a more pelagic trophic niche when coexisting with a strong and predominantly benthivorous resource competitor (here (ㄷ) 2012 Blackwell Publishing Ltd, Freshwater Biology, 58, 207-221 trout). In the studied lakes, trout dominated the littoral trophic niche and relied mainly on littoral carbon sources (average 65-99\%). According to two-source isotopic mixing models (cf. Karlsson \& Byström, 2005; Parnell et al., 2010), charr relied on average $30 \%$ less on littoral carbon in our five study lakes (on average $32-62 \%$ ) than in ten previously studied Swedish and Finnish subarctic lakes (on average 62$94 \%$; Karlsson \& Byström, 2005; Eloranta et al., 2010) where charr lived in allopatry or coexisted with nine-spined stickleback (Pungitius pungitius L.). Hence, our study suggests that interspecific interactions may significantly alter energy mobilisation to top consumers in subarctic lakes. Compared to our five study lakes $\left(Z_{\max }=48-92 \mathrm{~m}\right)$, the study lakes of Karlsson \& Byström (2005) and Eloranta et al. 
214 A. P. Eloranta et al.

Table 1 Summary of trophic niche metrics based on individual variation in stomach contents $(B=$ Levins index, $1-I S=$ prevalence for individual specialization, where $I S=$ mean $\pm \mathrm{SD}$ of individual $\left.P S_{i}\right)$ and in muscle $\delta^{13} \mathrm{C}$ and $\delta^{15} \mathrm{~N}$ values $\left(S E A_{B}=\right.$ mean and the upper and lower $95 \%$ Bayesian credibility intervals for standard ellipse area) of all charr and trout and of pelagic-caught and littoral-caught charr. Samples sizes (n) are shown for both SCA and SIA

\begin{tabular}{|c|c|c|c|c|c|}
\hline & \multicolumn{3}{|c|}{ SCA } & \multicolumn{2}{|l|}{ SIA } \\
\hline & $n$ & $B$ & $1-I S$ & $n$ & $S E A_{B}\left(\%{ }^{2}\right)$ \\
\hline \multicolumn{6}{|l|}{ Lille Rostavatn } \\
\hline Charr & 106 & 2.9 & $0.45 \pm 0.25$ & 102 & $2.03(1.64-2.43)$ \\
\hline Trout & 28 & 2.1 & $0.44 \pm 0.24$ & 27 & $2.65(1.72-3.66)$ \\
\hline Pelagic charr & 34 & 2.7 & $0.25 \pm 0.12$ & 30 & $0.64(0.42-0.86)$ \\
\hline Littoral charr & 25 & 5.2 & $0.75 \pm 0.14$ & 25 & $2.98(1.92-4.25)$ \\
\hline \multicolumn{6}{|l|}{ Fjellfrøsvatn } \\
\hline Charr & 119 & 7.3 & $0.68 \pm 0.16$ & 121 & $5.71(4.72-6.77)$ \\
\hline Trout & 37 & 2.8 & $0.65 \pm 0.25$ & 40 & $4.72(3.31-6.22)$ \\
\hline Pelagic charr & 32 & 3.0 & $0.35 \pm 0.12$ & 32 & $1.80(1.22-2.45)$ \\
\hline Littoral charr & 55 & 8.4 & $0.73 \pm 0.11$ & 58 & $5.96(4.49-7.55)$ \\
\hline \multicolumn{6}{|l|}{ Takvatn } \\
\hline Charr & 88 & 8.8 & $0.67 \pm 0.19$ & 145 & $6.14(5.17-7.16)$ \\
\hline Trout & 101 & 4.1 & $0.63 \pm 0.21$ & 100 & $4.14(3.36-4.97)$ \\
\hline Pelagic charr & 14 & 6.5 & $0.45 \pm 0.19$ & 21 & $2.81(1.7-4.05)$ \\
\hline Littoral charr & 57 & 9.2 & $0.70 \pm 0.16$ & 82 & $5.77(4.54-7.05)$ \\
\hline \multicolumn{6}{|l|}{ Sagelvvatn } \\
\hline Charr & 107 & 2.3 & $0.48 \pm 0.23$ & 103 & $3.00(2.46-3.60)$ \\
\hline Trout & 102 & 3.2 & $0.63 \pm 0.19$ & 97 & $6.13(4.94-7.41)$ \\
\hline Pelagic charr & 35 & 1.4 & $0.19 \pm 0.14$ & 35 & $0.78(0.53-1.04)$ \\
\hline Littoral charr & 43 & 1.6 & $0.31 \pm 0.23$ & 39 & $2.24(1.56-2.95)$ \\
\hline \multicolumn{6}{|l|}{ Josefvatn } \\
\hline Charr & 113 & 3.9 & $0.68 \pm 0.14$ & 101 & $6.37(5.17-7.64)$ \\
\hline Trout & 98 & 2.6 & $0.58 \pm 0.21$ & 96 & $4.23(3.41-5.10)$ \\
\hline Pelagic charr & 36 & 1.4 & $0.31 \pm 0.29$ & 36 & $1.12(0.77-1.49)$ \\
\hline Littoral charr & 23 & 4.7 & $0.72 \pm 0.13$ & 23 & $8.20(5.12-11.7)$ \\
\hline
\end{tabular}

(2010) were shallower $\left(Z_{\max }=4.2-24 \mathrm{~m}\right)$ and thus might have relatively higher benthic production supporting the charr populations. However, despite the strong negative relationship between lake depth and benthic primary production, Vander Zanden et al. (2011) found no correlation between lake depth and fish littoral reliance, but instead a generally more efficient mobilisation of littoral carbon to higher trophic levels.

The observed partial niche segregation between charr and trout presumably decreases competitive interactions and thereby facilitates coexistence of the species in subarctic lakes ( $c f$. interactive segregation hypothesis: Nilsson, 1967; Langeland et al., 1991; Hammar, 1998). However, despite the differences in diets and isotopic compositions, charr and trout showed a partial habitat overlap within the littoral zone in all the study lakes. Trout have commonly been suggested to force charr into a pelagic or profundal habitat and diet (Nilsson, 1963; Langeland et al., 1991). In winter, however, competitive dominance may shift as charr are better adapted than trout to feed on zoobenthos under cold and dark conditions (Hammar, 1998; Amundsen \& Knudsen, 2009; Elliott, 2011; Helland et al., 2011). Correspondingly, charr have also been observed outcompeting trout in cold, ultraoligotrophic lakes situated at high altitudes and latitudes (Svärdson, 1976; Finstad et al., 2011). Nevertheless, our findings show that, at least in some subarctic lakes, charr and trout can coexist in the littoral zone in the summer. This coexistence in the littoral habitat is probably mediated by a dietary segregation, as charr consumed cladoceran zooplankton and had depleted $\delta^{13} \mathrm{C}$ values compared to trout that fed on typical zoobenthos prey. Extensive planktivory by charr residing in the littoral zone highlights the trophic niche plasticity of the species, which is probably an adaptation to seasonal fluctuations of, and interspecific competition for, limited food (e.g. Klemetsen et al., 2003a; Amundsen \& Knudsen, 2009). Our diet data indicate that, at least in our clear-water study lakes, zooplankton are present in near-shore areas where they might provide a significant, alternative energy source for littoral-dwelling charr. Hence, the two fish species may also reduce both encounters and interference competition through niche segregation at a microhabitat level within the littoral zone. Moreover, the partial planktivorous foraging of littoral-caught charr indicates that littoral and pelagic habitats and food-web compartments may be

(c) 2012 Blackwell Publishing Ltd, Freshwater Biology, 58, 207-221 

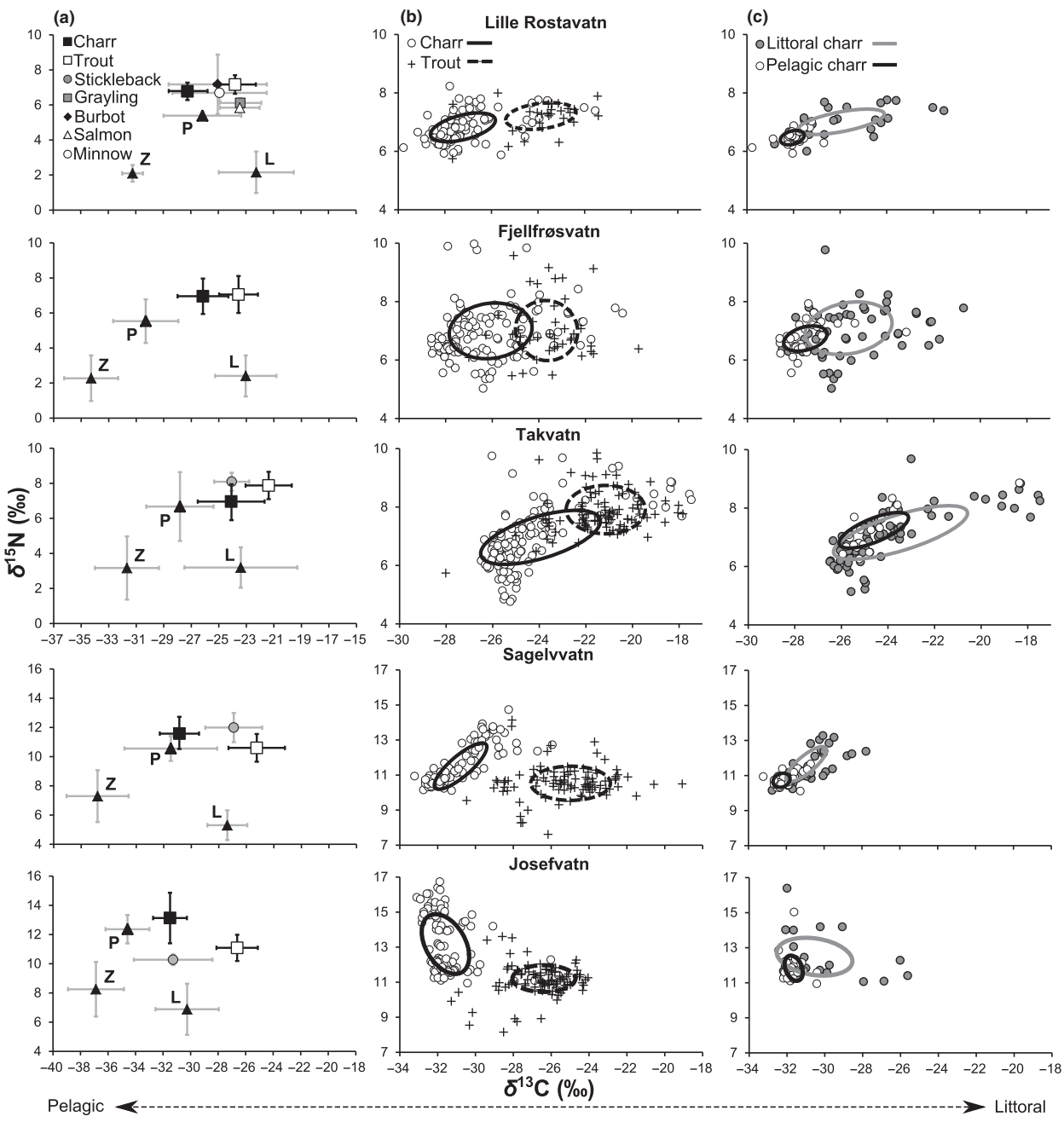

Fig. 3 Stable isotope biplots showing (a) the mean $(+\mathrm{SD}) \delta^{13} \mathrm{C}$ and $\delta^{15} \mathrm{~N}$ values of fish muscle tissue and of zooplankton (Z), littoral zoobenthos (L) and profundal zoobenthos $(\mathrm{P})$, and the individual isotopic values and the estimated isotopic niches $\left(S E A_{c}\right)$ of $(\mathrm{b})$ all charr and trout and of (c) pelagic-caught and littoral-caught charr. Note the different $x$ - and $y$-axis scales in Sagelvvatn and Josefvatn due to deviant isotopic baselines in the lakes. The estimated isotopic niche widths $\left(S E A_{B}\right)$ are given in Table 1.

highly integrated (see Polis et al., 1997; Schindler \& Scheuerell, 2002; Vadeboncoeur et al., 2002). However, some littoral-caught charr may also have been mainly feeding in the pelagic zone but only briefly visited in the littoral zone prior to capture.

(C) 2012 Blackwell Publishing Ltd, Freshwater Biology, 58, 207-221
The observed niche segregation between the predominantly planktivorous charr and the insectivorous trout may be a consequence of both selective and interactive processes. In their experimental studies, Jansen et al. (2002) showed that, relative to trout, charr are superior 
216 A. P. Eloranta et al.

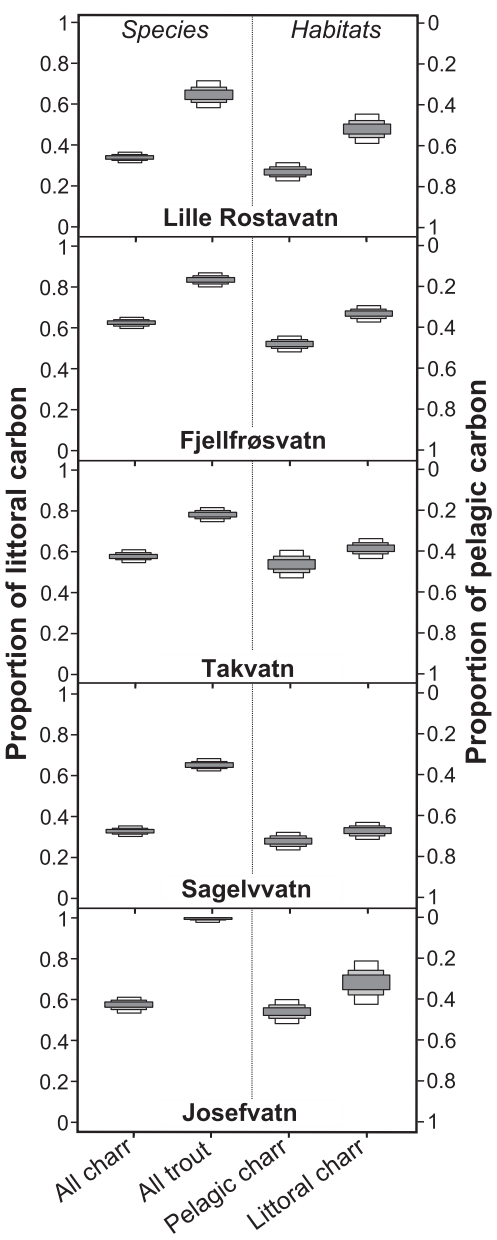

Fig. 4 Proportions of littoral ( $y$-axis on the left) and pelagic (inverse $\mathrm{y}$-axis on the right) dietary carbon in charr and trout (Species) and in pelagic-caught and littoral-caught charr (Habitats) sampled from the five study lakes. The boxes indicte 95, 75 and 50\% Bayesian c bility intervals for estimates based on SIAR isotopic mixing model. Sample sizes are given in Table 1.

zooplankton foragers, whereas trout are more aggressive and effective in feeding on large epibenthic prey. Hence, they argued that the commonly observed niche segregation between charr and trout may not only result from the aggressive interference by trout, but also from selective differences in foraging performances of the two species. Correspondingly, Forseth et al. (2003) experimentally showed that charr may not necessarily turn to benthivory in the absence of trout. Furthermore, they found a directional selection in trophic morphology and feeding behaviour with a loss of the benthivorous trait of charr in sympatry with trout. Previous field studies from Lille Rostavatn and Fiellfrøsvatn have also demonstrated that the charr populations have adapted their morphology to planktivory due to strong interspecific resource competition for benthic food (Knudsen et al., 2007, 2011). Thus, charr may evolve an adaptation to a planktivorous niche through ecological character displacement caused by interspecific competition. The inherent and/or evolved differences in feeding behaviour of charr and trout probably account for the observed niche segregation (Figs 2a, 3b and 4) and facilitate the partially overlapping habitat use by the two species in our study lakes (Fig. 1). However, it should be emphasised that in allopatry the two species are known to utilise similar resources (e.g. Nilsson, 1963, 1967), so the observed niche segregation is probably also due to competitive interactions.

Trophic niche width of charr and trout

Our results from habitat use and dietary analyses generally demonstrated higher potential for niche plasticity and benthic-pelagic coupling in charr as compared to the more strictly littoral-dwelling insectivorous trout. However, despite a generally narrower trophic niche, trout may indirectly increase habitat and food-web coupling in subarctic lakes by forcing charr to a more pelagic trophic niche and to seasonal niche shifts as previously observed (e.g. in Fjellfrøsvatn; Amundsen \& Knudsen, 2009). The exceptional niche plasticity of charr has also been shown to facilitate coexistence with some planktivorous fish species, such as European whitefish (Eloranta et al., 2011) and roach (Rutilus rutilus L.; Corrigan et al., 2011). In our five study lakes, charr seemed to switch their habitat use and trophic niche depending on the prevailing resource competition for littoral resources. Firstly, charr and trout had the most overlapping dietary and isotopic niches in Fjellfrøsvatn and Takvatn, where charr numerically dominated or had a similar density to trout in the littoral and thus had attained a partial benthivorous niche expansion. Such a niche expansion may also result from strong intraspecific competition inducing individual niche specialisation (cf. Bolnick et al., 2010; Araújo et al., 2011). Bolnick et al. (2011) argued that a wide population niche not only alleviates intraspecific competition, but also affects the outcome of interspecific competition by simultaneously increasing diet overlap with other species and reducing the impact of this overlap as only subsets of 
individuals in each species are affected. Secondly, benthivorous trout and grayling were relatively abundant in Sagelvvatn and Lille Rostavatn, respectively, and presumably forced the whole charr population to a narrow planktivorous dietary niche. Such population-level specialisation of charr towards planktivory seems temporally stable as suggested by an earlier study in Lille Rostavatn (Knudsen et al., 2007). Thirdly, the partial shift of adult charr to the profundal zone in Josefvatn illustrates the plastic habitat use by this species, reducing competitive interactions with abundant trout in the littoral zone. The profundal niche use of charr in Josefvatn also explains the large individual variation in $\delta^{15} \mathrm{~N}$ values, possibly resulting from substantial foraging on profundal chironomid larvae or pupae with high $\delta^{15} \mathrm{~N}$ values.

Intrapopulation niche specialisation in charr and benthicpelagic coupling

The generally wide trophic niche of charr at the population level evidently resulted from individual niche specialisation for various food resources, as demonstrated by the dietary and isotopic niche metrics. Thus, our results support the concept that more generalised populations might actually be more heterogeneous as a consequence of individual niche specialisation (Bolnick et al., 2007). Furthermore, our findings illustrate partial intrapopulation niche segregation between the pelagic-caught and littoralcaught charr, particularly in Lille Rostavatn and Fjellfrøsvatn. The pelagic-caught charr had a narrower trophic niche and relied significantly less on littoral carbon sources than their littoral-caught conspecifics. In contrast, the results from SCA and SIA suggest a significantly higher degree of individual niche specialisation for littoral-caught charr, which consisted of generalists and benthivorous and planktivorous specialists. Due to their more plastic trophic niche, the littoral-dwelling charr probably have a higher potential to promote benthicpelagic coupling than their pelagic-caught conspecifics. However, the results from two-source isotopic mixing model suggest that both charr subpopulations rely substantially on littoral and pelagic carbon sources and thus may act as important food-web couplers in the five study lakes. The observed partial reliance of pelagic-caught planktivorous charr on littoral carbon sources may reflect general niche plasticity and/or consumption of pleuston originating from the littoral or profundal zone that has a higher $\delta^{13} \mathrm{C}$ value than the predominant zooplankton diet. Because of the long turnover time of muscle tissue (Hesslein et al., 1993; Buchheister \& Latour, 2010), the isotopic composition of pelagic-caught charr may also () 2012 Blackwell Publishing Ltd, Freshwater Biology, 58, 207-221 partly reflect their spring-time diet, which is likely to have been dominated by littoral zoobenthos at a time when zooplankton is extremely sparse in these lakes (Amundsen et al., 2008; Amundsen \& Knudsen, 2009; Eloranta et al., 2010).

In addition to charr (Klemetsen, 2010 and references therein), niche partitioning between pelagic and littoral subpopulations has been observed in other generalist fish species in post-glacial lakes (e.g. Bolnick et al., 2003; Quevedo et al., 2009). The intrapopulation niche segregation between pelagic and littoral charr observed across lakes may also be stable in time (over 15 years) as demonstrated by an earlier study of charr in Fjellfrøsvatn (Knudsen et al., 2010a,b). The observed differences in trophic niche widths of pelagic-caught and littoral-caught charr reflect the diversity and special characteristics of the available food sources. The generally more productive and heterogeneous littoral zone is inhabited by largebodied zoobenthos, while the pelagic zone offers relatively scarce and small-bodied zooplankton as prey for the fish (Schindler \& Scheuerell, 2002). Hence, a narrow planktivorous niche of pelagic-dwelling fish could be explained by restricted food resources (Schindler \& Scheuerell, 2002; Quevedo et al., 2009) and by higher foraging efficiency of specialised individuals (Bolnick et al., 2003; Araújo et al., 2011). In contrast, in the littoral zone, generalist fish may have an opportunity to choose between flexible and specialised benthivorous or planktivorous foraging as shown by our results. The high degree of individual specialisation observed in littoralcaught charr may also result from strong intraspecific and/or interspecific resource competition in the littoral zone (Amundsen, 1995; Bolnick et al., 2003; Eloranta et al., 2010). The ability to exploit different prey items, including the temporarily abundant zooplankton in the pelagic open-water area, can also significantly depend on the individual's size, potentially affecting predation risk and competitive dominance within the population (Hegge et al., 1989; L'Abée-Lund et al., 1993; Eloranta et al., 2010). This may explain the significantly larger size of pelagiccaught charr in Fjellfrøsvatn, Takvatn and Sagelvvatn where a few large piscivorous trout were observed.

Congruent with our findings from charr, a study of perch (Perca fluviatilis L.) showed a narrower and more stable trophic niche (i.e. lower frequency of individual diet specialisation) for pelagic individuals as compared to the littoral conspecifics (Quevedo et al., 2009). Quevedo et al. (2009) concluded that intrapopulation niche partitioning in generalist fish may limit the coupling between spatially separated pelagic and littoral food chains (cf. Vander Zanden \& Vadeboncoeur, 2002). Our results 
218 A. P. Eloranta et al.

indicate that charr may show corresponding intrapopulation niche partitioning in subarctic lakes, but the extent of niche segregation seemed to differ among lakes, probably due to contrasting patterns in interspecific and intraspecific resource competition within the fish communities. For example, relative to the other three study lakes, the pelagic-caught and littoral-caught charr had overlapping trophic niches in Sagelvvatn and Takvatn because of population-level specialisation into zooplankton diet in the former and an exceptionally wide trophic niche of pelagic-caught charr in the latter lake (Figs $2 b$ and 3c, Table 1). In contrast, charr in Lille Rostavatn have been shown to be largely restricted to the pelagic niche due to strong interspecific competition for littoral resources (Knudsen et al., 2007), whereas in Fjellfrøsvatn, where strong intraspecific competition is probably predominant, the pelagic and littoral charr have been found to show temporally stable feeding specialisation to planktivorous and benthivorous diets, respectively (Knudsen et al., 2010a,b). Hence, both intraspecific and interspecific resource competition may affect the trophic niche plasticity of individuals and populations, thereby probably further altering the coupling of benthic and pelagic habitats and food-web compartments.

Hecky \& Hesslein (1995) found that, compared to tropical lakes, fish consumers in temperate and Arctic lakes were increasingly generalist, as shown by their intermediate $\delta^{13} \mathrm{C}$ values. Our findings corroborate this pattern of generalistic foraging behaviour by top trophiclevel fish. In most of our study lakes, charr clearly relied on both littoral and pelagic carbon sources. Generalist fish consumers, including charr, may thus have a major role in lake ecosystems as integrators of benthic and pelagic food-web compartments (Polis et al., 1997; Schindler \& Scheuerell, 2002; Vander Zanden \& Vadeboncoeur, 2002) as well as being controllers of food-web stability and dynamics, as suggested by trophic network theory (Vadeboncoeur et al., 2005). Correspondingly, the observed generalistic and plastic foraging behaviour of littoraldwelling charr may be assumed to promote persistence and stability of littoral food-web compartments by dampening consumer-resource oscillations (Bolnick et al., 2011). The present and previous findings suggest that both niche segregation between sympatric charr and trout, and niche specialisation within pelagic-caught and littoral-dwelling charr subpopulations may restrict food-web coupling, whereas the general niche plasticity of charr, including potential seasonal and ontogenetic habitat and diet shifts (see Klemetsen et al., 2003b; Amundsen et al., 2008; Eloranta et al., 2010), probably promotes habitat and food-web connectivity in subarctic lakes.
In conclusion, our study has shown that the reliance of top consumers, such as charr and trout, on benthic production in oligotrophic high-latitude lakes can depend strongly on interspecific interactions between sympatric fish species as well as on individual niche specialisation within the populations. Our results also confirm a large trophic niche plasticity of charr, which facilitates coexistence with sympatric competitors and potentially increases habitat and food-web coupling. Despite apparent differences in the physical and biological characteristics of the pelagic and littoral habitats and food-web compartments, our study illustrates that these main energy pathways in subarctic lakes are highly integrated and dynamic, largely due to the plastic foraging behaviour of top consumers such as charr.

\section{Acknowledgments}

We are grateful to Cesilie Lien, Laina Dalsbø, Emmanuela Daza Secco and other people helping with the field and laboratory work. We also appreciate the constructive comments on the manuscript given by Roger Jones and Kimmo Kahilainen as well as by two anonymous referees and Colin Townsend. The work was supported by personal grants to A.P. Eloranta from the Jenny and Antti Wihuri Foundation and the Ellen and Artturi Nyyssönen Foundation, and by project grants from the Norwegian Research Council provided to R. Knudsen and P.-A. Amundsen.

\section{References}

Amundsen P.-A. (1995) Feeding strategy of Arctic charr (Salvelinus alpinus): general opportunist, but individual specialist. Nordic Journal of Freshwater Research, 71, 150156.

Amundsen P.-A., Gabler H.-M. \& Staldvik F.J. (1996) A new approach to graphical analysis of feeding strategy from stomach contents data -modification of the Costello (1990) method. Journal of Fish Biology, 48, 607-614.

Amundsen P.-A. \& Klemetsen A. (1986) Within-sample variabilities in stomach contents weight of fish - implications for field studies of consumption rate. In: Contemporary Studies on Fish Feeding (Eds C. A. Simenstad \& G. M. Cailliet), pp. 307-314. Dr W. Junk Publishers, Dordrecht. Amundsen P.-A. \& Klemetsen A. (1988) Diet, gastric evacuation rates and food consumption in a stunted population of Arctic charr (Salvelinus alpinus L.) in Takvatn, northern Norway. Journal of Fish Biology, 33, 697-709.

Amundsen P.-A. \& Knudsen R. (2009) Winter ecology of Arctic charr (Salvelinus alpinus) and brown trout (Salmo trutta) in a subarctic lake, Norway. Aquatic Ecology, 43, 765-775.

(c) 2012 Blackwell Publishing Ltd, Freshwater Biology, 58, 207-221 
Amundsen P.-A., Knudsen R. \& Bryhni H.T. (2010) Niche use and resource partitioning of Arctic charr, European whitefish and grayling in a subarctic lake. Hydrobiologia, 650, 3-14.

Amundsen P.-A., Knudsen R. \& Klemetsen A. (2008) Seasonal and ontogenetic variations in resource use of two sympatric Arctic charr morphs. Environmental Biology of Fishes, 83, 45-56.

Araújo M.S., Bolnick D.I. \& Layman C.A. (2011) The ecological causes of individual specialization. Ecology Letters, 14, 948-958.

Araújo M.S., Bolnick D.I., Machado G., Giaretta A.A. \& dos Reis S.F. (2007) Using $\delta^{13} \mathrm{C}$ stable isotopes to quantify individual-level diet variation. Oecologia, 152, 643-654.

Bearhop S., Adams C. E., Waldron S., Fuller R. A. \& Macleod H. (2004) Determining trophic niche width: a novel approach using stable isotope analysis. Journal of Animal Ecology, 73, 1007-1012.

Boecklen W.J., Yarnes C.T., Cook B.A. \& James A.C. (2011) On the use of stable isotopes in trophic ecology. Annual Review of Ecology, Evolution, and Systematics, 42, 411-440.

Bolnick D.I., Amarasekare P., Araújo M.S., Bürger R., Levine J.M., Novak M. et al. (2011) Why intraspecific trait variation matters in community ecology? Trends in Ecology and Evolution, 26, 183-192.

Bolnick D.I., Ingram T., Stutz W.E., Snowberg L.K., Lee Lau O. \& Paull J.S. (2010) Ecological release from interspecific competition leads to decoupled changes in population and individual niche width. Proceedings of the Royal Society B, 277, 1789-1797.

Bolnick D.I., Svanbäck R., Araújo M.S \& Persson L. (2007) Comparative support for the niche variation hypothesis that more generalized populations also are more heterogeneous. Proceedings of the National Academy of Sciences, 104, 10075-10079.

Bolnick D.I., Svanbäck R., Fordyce J.A., Yang L.H., Davis J.M., Hulsey C.D. et al. (2003) The ecology of individuals: incidence and implications of individual specialization. American Naturalist, 161, 1-28.

Bolnick D.I., Yang L.H., Fordyce J.A., Davis J.M. \& Svanbäck R. (2002) Measuring individual-level resource specialization. Ecology, 83, 2936-2941.

Bowen S.H. (1996) Quantitative description of the diet In: Fisheries Techniques (Eds B.R. Murphy \& D.W. Willis), pp. 513-532. American Fisheries Society, Bethesda, Maryland.

Buchheister A. \& Latour R.J. (2010) Turnover and fractionation of carbon and nitrogen stable isotopes in tissues of a migratory coastal predator, summer flounder (Paralichthys dentatus). Canadian Journal of Fisheries and Aquatic Sciences, 67, 445-461.

Christoffersen K.S., Jeppesen E., Moorhead D.L. \& Tranvik L.J. (2008) Food-web relationships and community structures in high-latitude lakes. In: Polar Lakes and Rivers: Limnology of Arctic and Antarctic Aquatic Ecosystems (Eds
W.F. Vincent \& J. Laybourn-Parry), pp. 269-289. Oxford University Press, New York

Corrigan L.J., Winfield I.J., Hoelzel A.R. \& Lucas M.C. (2011) Dietary plasticity in Arctic charr (Salvelinus alpinus) in response to long-term environmental change. Ecology of Freshwater Fish, 20, 5-13.

Elliott J.M. (2011) A comparative study of the relationship between light intensity and feeding ability in brown trout (Salmo trutta) and Arctic charr (Salvelinus alpinus). Freshwater Biology, 56, 1962-1972.

Eloranta A.P., Kahilainen K.K. \& Jones R.I. (2010) Seasonal and ontogenetic shifts in diet of Arctic charr Salvelinus alpinus in a subarctic lake. Journal of Fish Biology, 77, 80-

Eloranta A.P., Siwertsson A., Knudsen R. \& Amundsen P.-A. (2011) Dietary plasticity of Arctic charr (Salvelinus alpinus) facilitates coexistence with competitively superior European whitefish (Coregonus lavaretus). Ecology of Freshwater Fish, 20, 558-568.

Finstad A.G., Forseth T., Jonsson B., Bellier E., Hesthagen T., Jensen A.J. et al. (2011) Competitive exclusion along climate gradients: energy efficiency influences the distribution of two salmonid fishes. Global Change Biology, 17, 1703-1711.

Forseth T., Ugedal O., Jonsson B. \& Fleming A. (2003) Selection on Arctic charr generated by competition from brown trout. Oikos, 101, 467-478.

Hammar J. (1998) Interactive asymmetry and seasonal niche shifts in sympatric Arctic char (Salvelinus alpinus) and brown trout (Salmo trutta): evidence from winter diet and accumulation of radiocesium. Nordic Journal of Freshwater Research, 74, 33-64.

Hecky R.E. \& Hesslein R.H. (1995) Contributions of benthic algae to lake food webs as revealed by stable isotope analysis. Journal of the North American Benthological Society, 14, 631-653.

Hegge O., Dervo B.K., Skurdal J. \& Hessen D.O. (1989) Habitat utilization by sympatric Arctic charr (Salvelinus alpinus (L.)) and brown trout (Salmo trutta L.) in Lake Atnsjø, south-east Norway. Freshwater Biology, 22, 143-152. Helland I.P., Finstad A.G., Forseth T., Hesthagen T. \& Ugedal O. (2011) Ice-cover effects on competitive interactions between two fish species. Journal of Animal Ecology, 80, 539-547.

Hesslein R.H, Hallard K.A \& Ramlal P. (1993) Replacement of sulfur, carbon, and nitrogen in tissue of growing broad whitefish (Coregonus nasus) in response to a change in diet traced by $\delta^{34} \mathrm{~S}, \delta^{13} \mathrm{C}$, and $\delta^{15} \mathrm{~N}$. Canadian Journal of Fisheries and Aquatic Sciences, 50, 2071-2076.

Jackson A.L., Inger R., Parnell A.C. \& Bearhop S. (2011) Comparing isotopic niche widths among and within communities: SIBER - Stable Isotope Bayesian Ellipses in R. Journal of Animal Ecology, 80, 595-602.

Jansen P.A., Slettvold H., Finstad A.G. \& Langeland A. (2002) Niche segregation between Arctic charr (Salvelinus alpinus) 
220 A. P. Eloranta et al.

and brown trout (Salmo trutta): an experimental study of mechanism. Canadian Journal of Fisheries and Aquatic Sciences, 59, 6-11.

Jeppesen E., Jensen J.P., Jensen C., Faafeng B., Hessen D.O., Søndergaard M. et al. (2003) The impact of nutrient state and lake depth on top-down control in the pelagic zone of lakes: a study of 466 lakes from the temperate zone to the Arctic. Ecosystems, 6, 313-325.

Karlsson J. \& Byström P. (2005) Littoral energy mobilization dominates energy supply for top consumers in subarctic lakes. Limnology and Oceanography, 50, 538-543.

Klemetsen A. (2010) The charr problem revisited: exceptional phenotypic plasticity promotes ecological speciation in postglacial lakes. Freshwater Reviews, 3, 49-74.

Klemetsen A., Amundsen P.-A., Dempson J.B., Jonsson B., Jonsson N., O'Conell M.F.O. et al. (2003a) Atlantic salmon Salmo salar L., brown trout Salmo trutta L. and Arctic charr Salvelinus alpinus (L.): a review of aspects of their life histories. Ecology of Freshwater Fish, 12, 1-59.

Klemetsen A., Knudsen R., Staldvik F.J. \& Amundsen P.-A. (2003b) Habitat, diet and food assimilation of Arctic charr under the winter ice in two subarctic lakes. Journal of Fish Biology, 62, 1082-1098.

Knudsen R., Amundsen P.-A. \& Klemetsen A. (2010a) Arctic charr in sympatry with burbot: ecological and evolutionary consequences. Hydrobiologia, 650, 43-54

Knudsen R., Amundsen P.-A., Primicerio R., Klemetsen A. \& Sørensen P. (2007) Contrasting niche-based variation in trophic morphology within Arctic charr populations. Evolutionary Ecology Research, 9, 1005-1021.

Knudsen R., Primicerio R., Amundsen P.-A. \& Klemetsen A. (2010b) Temporal stability of individual feeding specialization may promote speciation. Journal of Animal Ecology, 79, 161-168.

Knudsen R., Siwertsson A., Adams C.E., Garduño-Paz M., Newton J. \& Amundsen P.-A. (2011) Temporal stability of niche use exposes sympatric Arctic charr to alternative selection pressures. Evolutionary Ecology, 25, 589-604.

L'Abée-Lund J.H., Langeland A., Jonsson B \& Ugedal O. (1993) Spatial segregation by age and size in Arctic charr: a trade-off between feeding possibility and risk of predation. Journal of Animal Ecology, 62, 160-168.

Langeland A., L'Abée-lund J.H., Jonsson B. \& Jonsson N. (1991) Resource partitioning and niche shift in Arctic charr Salvelinus alpinus and brown trout Salmo trutta. Journal of Animal Ecology, 60, 895-912.

Layman C.A., Araújo M.S., Boucek R., Hammerschlag-Peyer C.M., Harrison E., Jud Z.R. et al. (2012) Applying stable isotope to examine food-web structure: an overview of analytical tools. Biological Reviews, 87, 545-562.

Layman C.A., Arrington D.A., Montaña C.G. \& Post D.M. (2007) Can stable isotope ratios provide for communitywide measures of trophic structure? Ecology, 88, 42-48.
Levins R. (1968) Evolution in Changing Environments: Some Theoretical Explorations. Princeton University Press, New Jersey.

McCann K.S., Rasmussen J.B. \& Umbanhowar J. (2005) The dynamics of spatially coupled food webs. Ecology Letters, 8, 513-523.

Nilsson N.-A. (1963) Interaction between trout and char in Scandinavia. Transactions of the American Fisheries Society, 92, 276-285.

Nilsson N.-A. (1967) Interactive segregation between fish species. In: The Biological Basis of Freshwater Fish Production. (Ed. S.D. Gerking ), pp. 295-313. Blackwell Scientific Publications, Oxford.

Parnell A.C., Inger R., Bearhop S. \& Jackson A.L. (2010) Source partitioning using stable isotopes: coping with too much variation. PLoS ONE, 5, e9672.

Polis G.A., Anderson W.B. \& Holt R.D. (1997) Toward an integration of landscape and food web ecology: the dynamics of spatially subsidized food webs. Annual Review of Ecology and Systematics, 28, 289-316.

Post D., Layman C., Arrington D., Takimoto G., Quattrochi J. \& Montaña C. (2007) Getting to the fat of the matter: models, methods and assumptions for dealing with the lipids in stable isotope analyses. Oecologia, 152, 179-189.

Post D.M. (2002) Using stable isotopes to estimate trophic position: models, methods, and assumptions. Ecology, 83, 703-718

Post D.M., Conners M.E. \& Goldberg D.S. (2000) Prey preferences by a top predator and the stability of linked food chains. Ecology, 81, 8-14.

Quevedo M., Svanbäck R. \& Eklöv P. (2009) Intrapopulation niche partitioning in a generalist predator limits food web connectivity. Ecology, 90, 2263-2274.

R Development Core Team (2012) R: a language and environment for statistical computing. R Foundation for Statistical Computing, Vienna, Austria.

Rooney N., McCann K., Gellner G. \& Moore J.C. (2006) Structural asymmetry and the stability of diverse food webs. Nature, 442, 265-269.

Sandlund O.T., Museth J., Næsje T.F., Rognerud S., Saksgård R., Hesthagen T. et al. (2010) Habitat use and diet of sympatric Arctic charr (Salvelinus alpinus) and whitefish (Coregonus lavaretus) in five lakes in southern Norway: not only interspecific population dominance? Hydrobiologia, 650, 27-41.

Schindler D.E. \& Scheuerell M.D. (2002) Habitat coupling in lake ecosystems. Oikos, 98, 177-189.

Schoener T.W. (1970) Nonsynchronous spatial overlap of lizards in patchy habitats. Ecology, 51, 408-418.

Sierszen M.E., McDonald M.E. \& Jensen D.A. (2003) Benthos as the basis for arctic lake food webs. Aquatic Ecology, 37, 437-445.

Svanbäck R. \& Persson L. (2004) Individual diet specialization, niche width and population dynamics: implications 
for trophic polymorphisms. Journal of Animal Ecology, 73, 973-982.

Svärdson G. (1976) Interspecific population dominance in fish communities of Scandinavian lakes. Report of the Institute of Freshwater Research, Drottningholm, 55, 144-171.

Vadeboncoeur Y., Jeppesen E., Vander Zanden M.J., Schierup H.-H., Christoffersen K. \& Lodge D.M. (2003) From Greenland to green lakes: cultural eutrophication and the loss of benthic pathways in lakes. Limnology and Oceanography, 48, 1408-1418.

Vadeboncoeur Y., McCann K.S., Vander Zanden M.J. \& Rasmussen J.B. (2005) Effects of multi-chain omnivory on the strength of trophic control in lakes. Ecosystems, 8, 682-693.

Vadeboncoeur Y., Vander Zanden M.J. \& Lodge D.M. (2002) Putting the lake back together: reintegrating benthic pathways into lake food web models. BioScience, 52, 45-54.

Vander Zanden M.J. \& Vadeboncoeur Y. (2002) Fishes as integrators of benthic and pelagic food webs in lakes. Ecology, 83, 2152-2161.

Vander Zanden M.J., Vadeboncoeur Y. \& Chandra S. (2011) Fish reliance on littoral-benthic resources and the distribution of primary production in lakes. Ecosystems, 14, 894-903.

Vanni M.J., Duncan J.M., González M.J. \& Horgan M.J. (2009) Competition among aquatic organisms. In: Encyclopedia of Inland Waters (Ed. G.E. Likens), pp. 395-404. Elsevier, Oxford.
Wallace R.K. (1981) An assessment of diet-overlap indexes. Transactions of the American Fisheries Society, 110, 72-76.

\section{Supporting Information}

Additional Supporting Information may be found in the online version of this article:

Table S1 Characteristics of the study lakes and the fork lengths of charr and trout and of pelagic- and littoralcaught charr caught with the multimesh survey nets

Table S2 Catches of charr and trout and of pelagic- and littoral-caught charr, and the numbers of analysed and empty stomachs in SCA and muscle samples in SIA

Table S3 Equations used in calculations of habitat and diet metrics

Table S4 Statistical comparisons of fork lengths, $P S_{i}$ indices and muscle $\delta^{13} \mathrm{C}$ and $\delta^{15} \mathrm{~N}$ values between all charr and trout and between pelagic- and littoral-caught charr

Table S5 Proportions of different prey taxa in the stomach contents of all charr and trout and of pelagic- and littoralcaught charr

(Manuscript accepted 7 October 2012) 